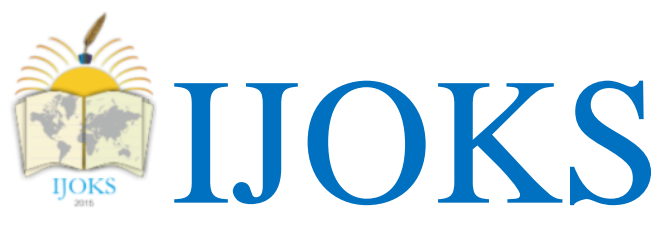

International Journal of Kurdish Studies

(ISSN:2149-2751)

5 (1), pp. $213-236$

http://www.ijoks.com

\title{
Economic conditions in the province of Erbil since the late Ottoman rule
}

\author{
Mahdi Mohammed QADER ${ }^{1}$ \& Fatah Bahram KHADER ${ }^{2}$
}

Received: Aug 06, 2018 Reviewed: Dec 06, 2018 Accepted: Dec 28, 2018

\begin{abstract}
Since the late nineteenth century and the beginning of the twentieth century, Erbil has been the administrative district of the province of Mosul. The fertility of its soil, its climate, and its location was economical and prestigious - its inhabitants have relied on agriculture to secure their lives. As they were interested in the production of some of the crops and crops that this research focused on in quantities and varieties of those products and crops accurately. Some were self-sustaining, such as wheat, barley, rice, as well as some other cash crops like tobacco and cotton. In addition, it has also been interested in the production of fruits and livestock. There is no doubt that each of these economic journals did not depart from natural and human problems and obstacles, And it was found to have affected the quantities and varieties of products and crops, and this has a negative impact on the lives of farmers.

As for the financial struggle in Erbil, the established financial system was the same as that which existed during the days of the Ottoman Empire. In addition to the archaic system, the Baathist regime had taken over Kurdish society - The lands of Erbil were divided into different types depending on the royal stratification of the Ottoman Empire, In the last section of this paper, we discuss the circumstances surrounding the residents of Erbil in the years of the First World War.
\end{abstract}

We have relied on sources from the Ottoman Empire, the British government, and a number of Kurdish and Arab sources.

Key words: Economic conditions, Province of Erbil, Ottoman Empire, British governments, Kurdish

\section{Recommended citation:}

Qader, M. M. \& Khader, F.B. (2019). Economic conditions in the province of Erbil since the late Ottoman rule. International Journal of Kurdish Studies 5 (1), 213 - 236 DOI: 10.21600/ ijoks.516506

${ }^{1}$ Prof., Salahaddin University, Erbil, Kurdistan Region, Iraq. E.mail:mahdi.muhammad86@yahoo.com, ${ }^{2}$ Correspondent Author: Assistant Lecturer and $\mathrm{PhD}$ student, Salahaddin University, Erbil, Kurdistan Region, Iraq. E.mail: fatahlak@yahoo.com, ORCID NO: https://orcid.org/0000-0002-7184-7298 


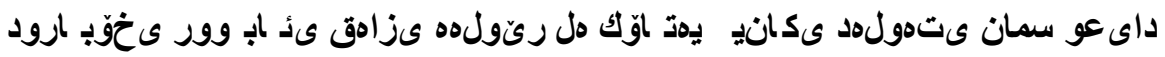 \\ م.ى. فتاح بهرام خضر \\ ب.د. مهدى محمد قادر 3
}

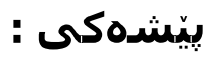

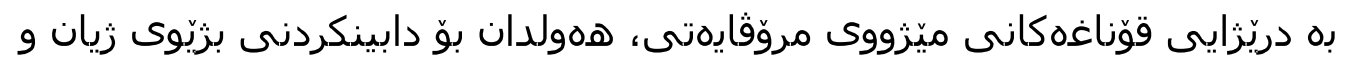

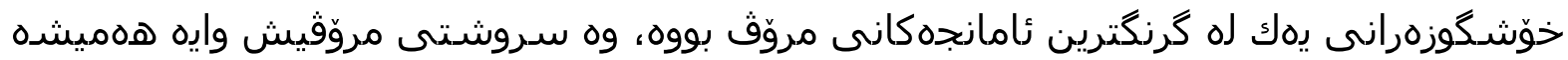

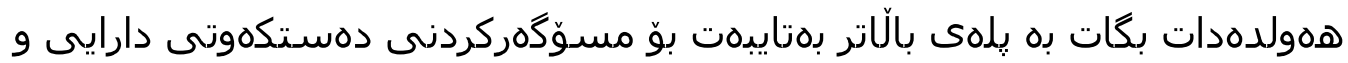

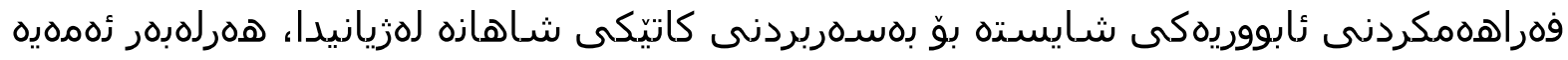

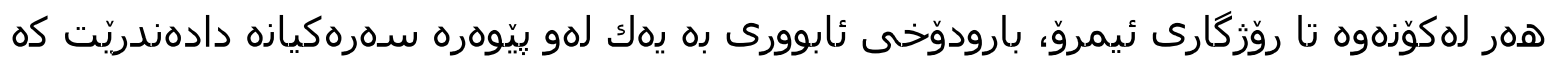

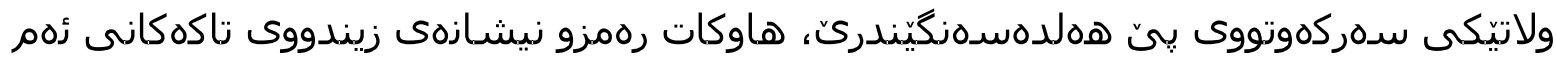

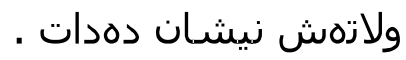

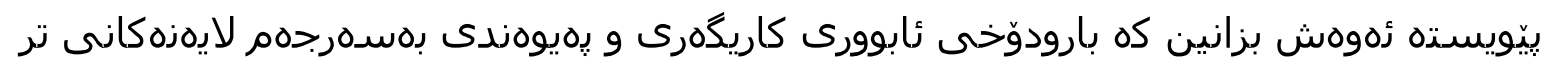

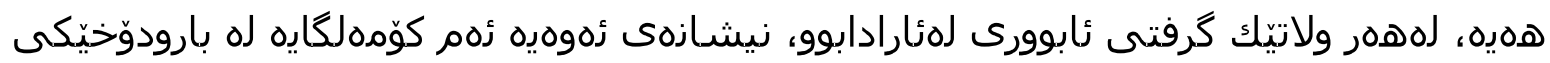

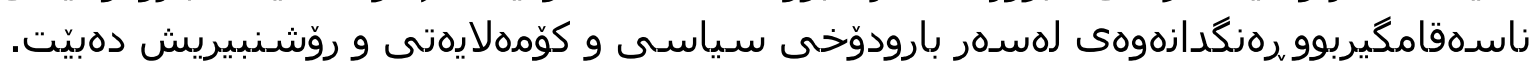

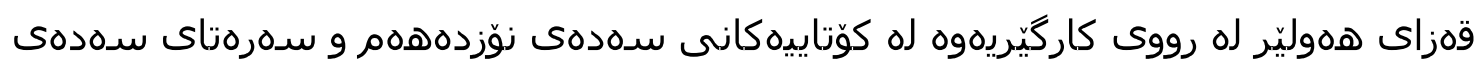

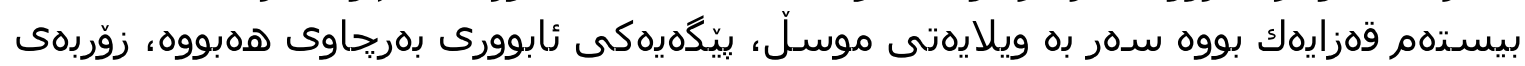

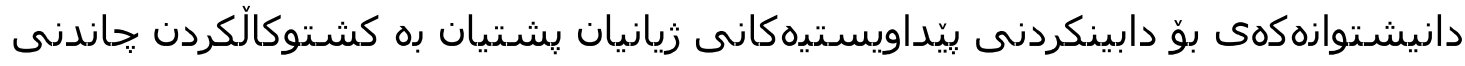

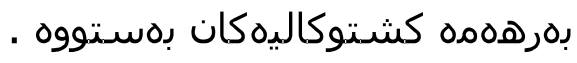

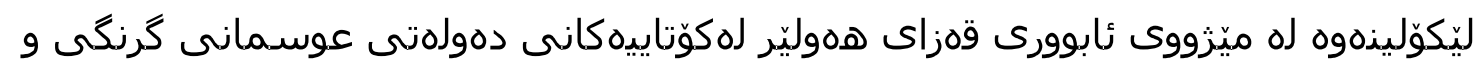

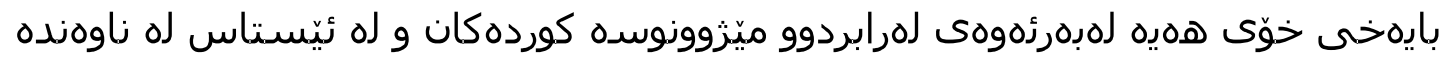

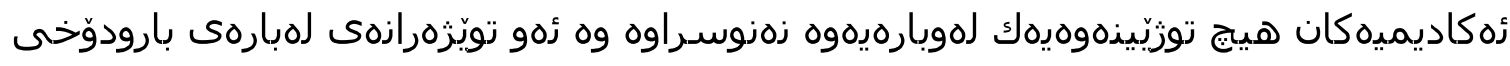

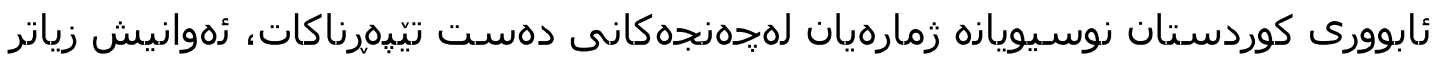

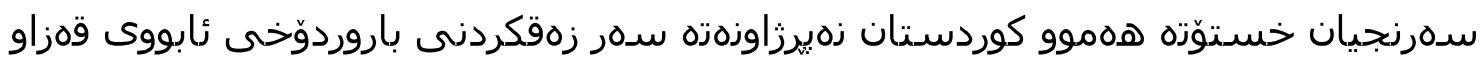
ناحيهكان و شارو شاروّيخكهكان

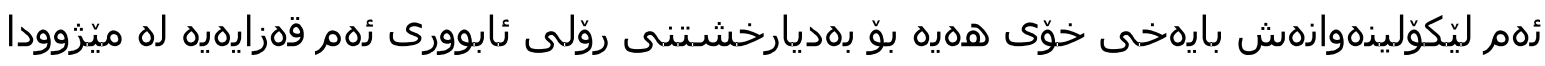

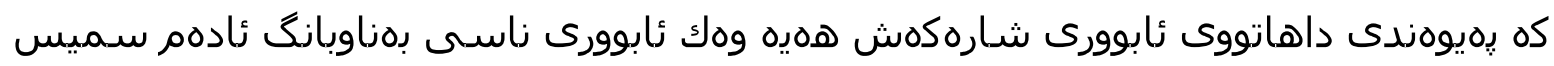

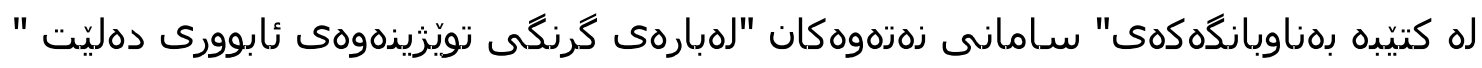

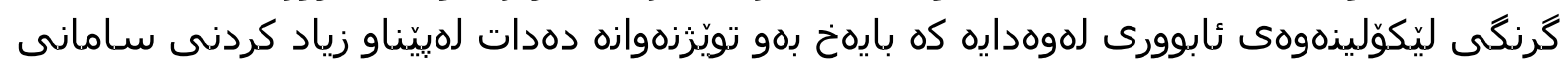

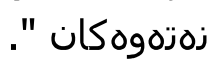

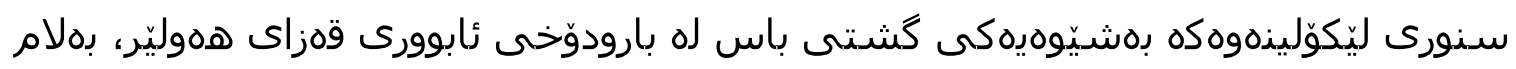

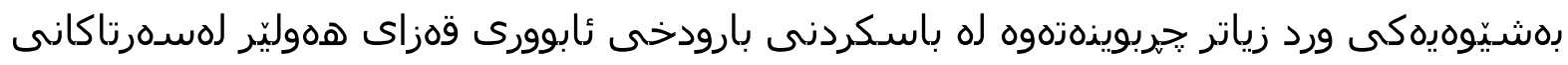

${ }^{3}$ Professor at the University of Salahaddin - Erbil.

${ }^{4}$ Assistant Lecturer and PhD students at Salahuddin University - Erbil International Journal of Kurdish Studies Vol.5/1 ( January 2019) 


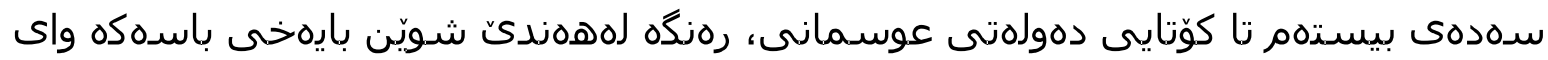

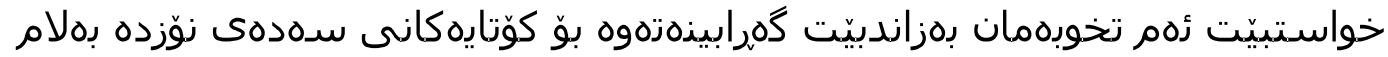

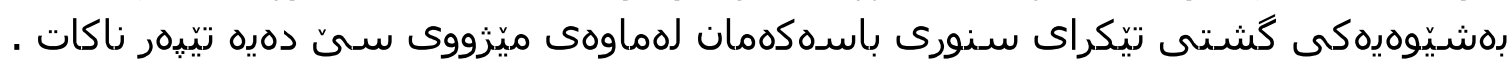

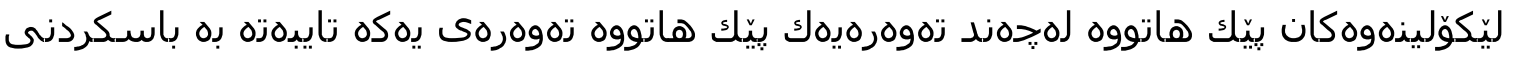

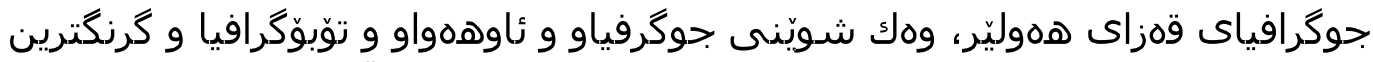

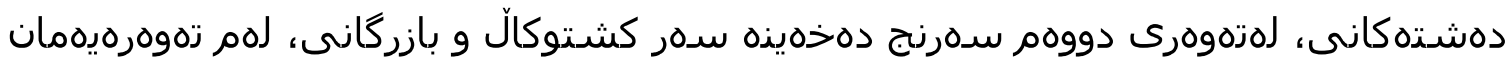

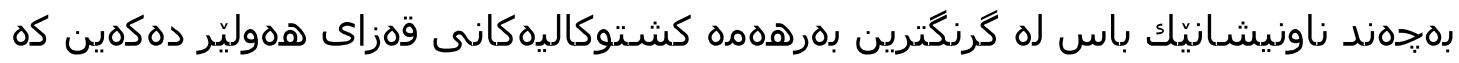

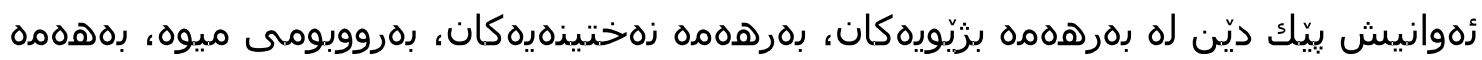

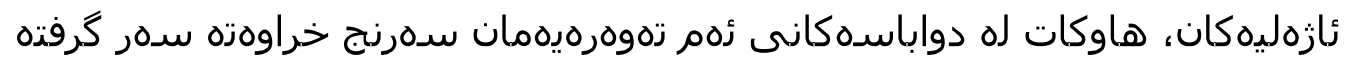

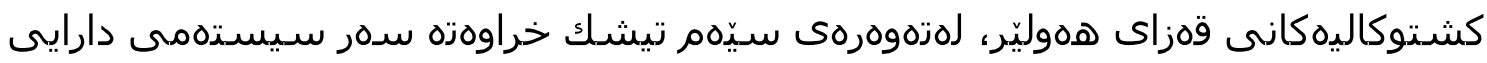

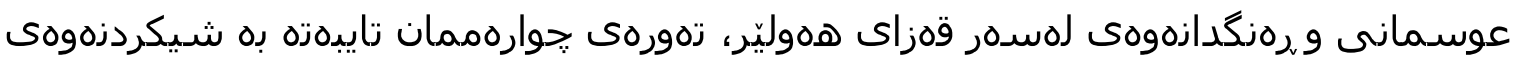

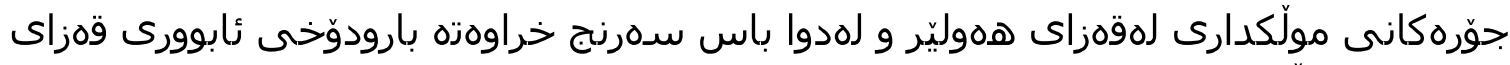

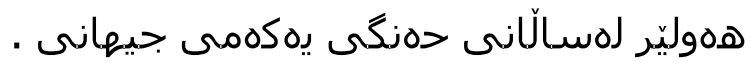

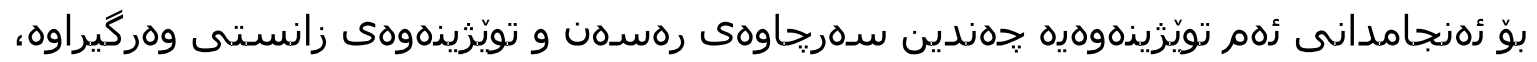

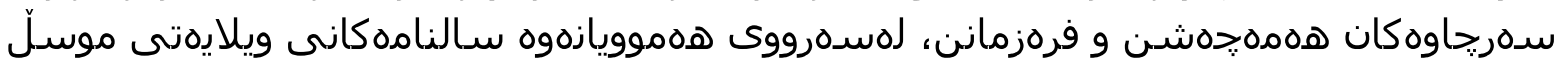

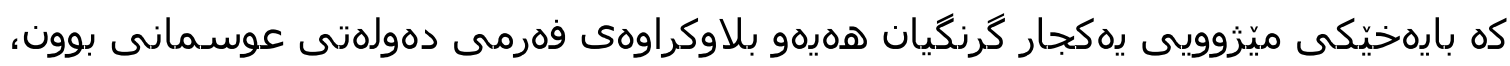

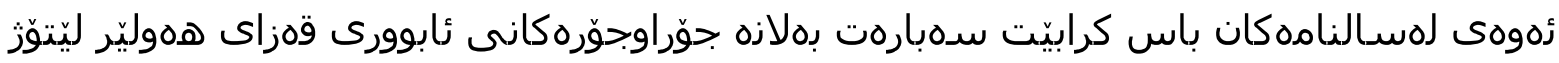

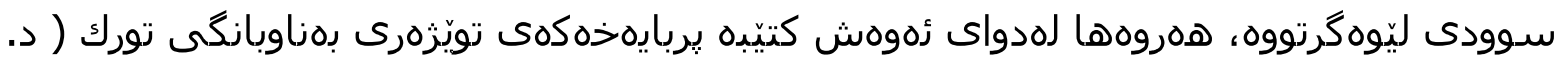
) باكورى عيّراق 1914-1931- 18SMANL DONEMINDE KUZEY IRAK لـسهردهمى عوسمانى

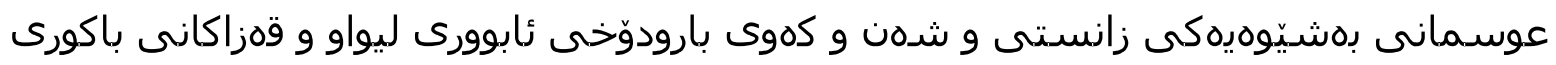

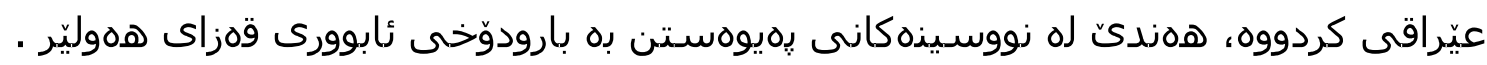

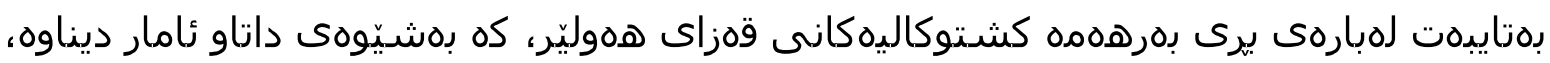

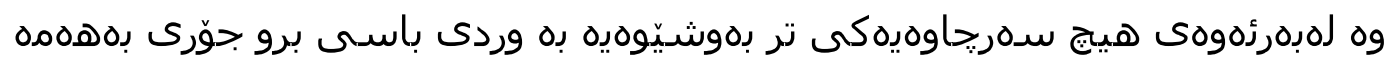

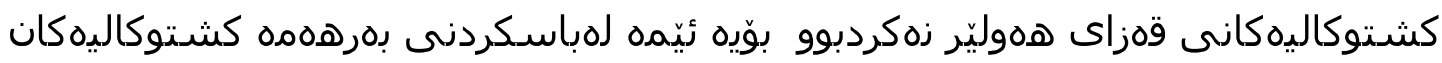

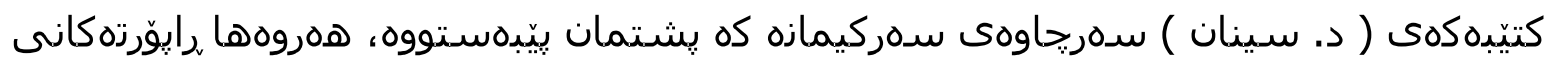

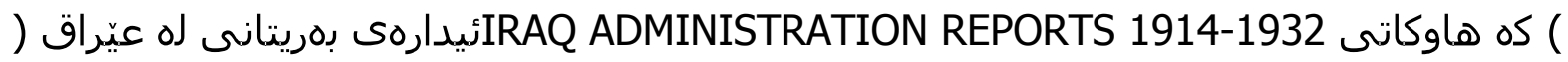

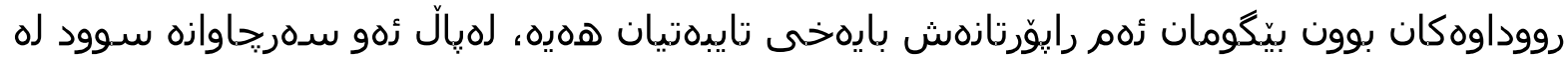

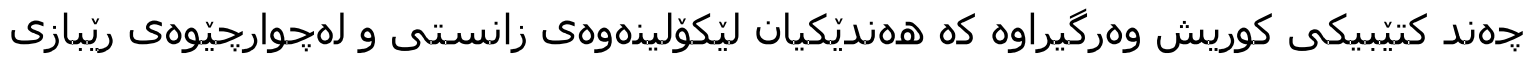

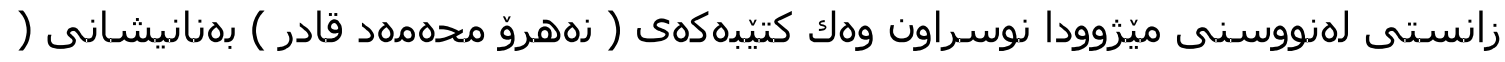

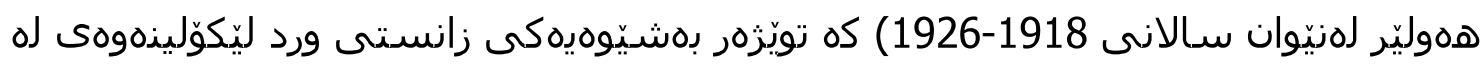

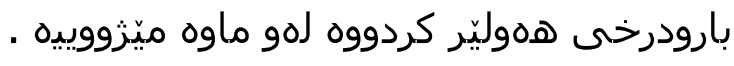

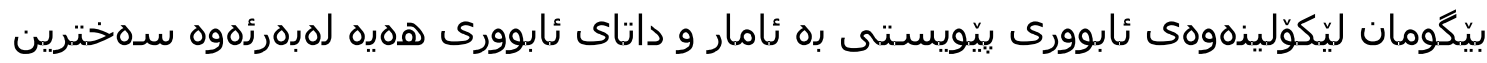

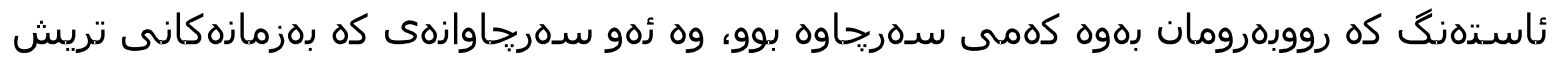

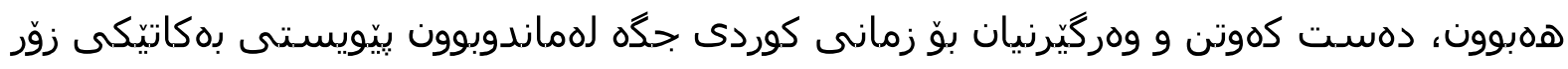
هذبووه .

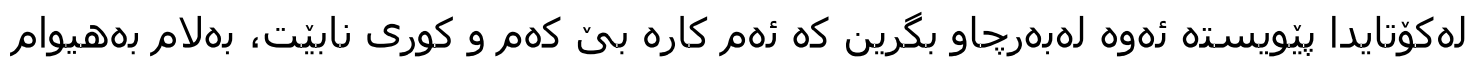

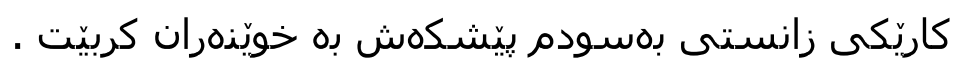




\section{يمهم : هoلومهرجى جوكرافى :}

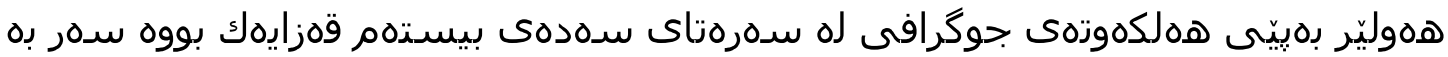

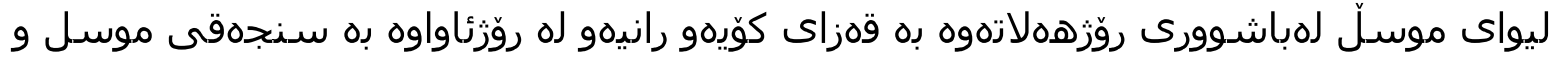

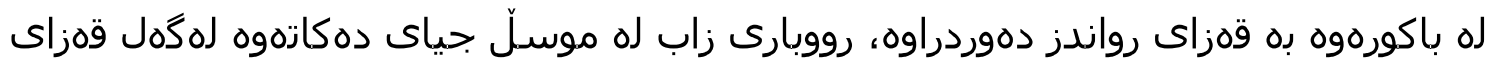

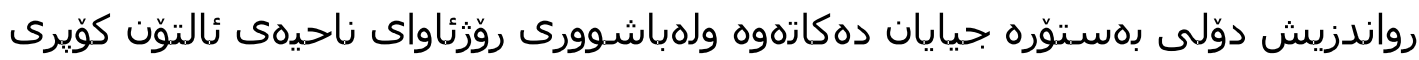

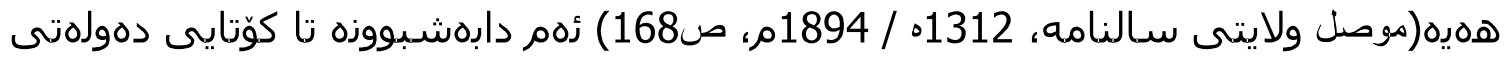

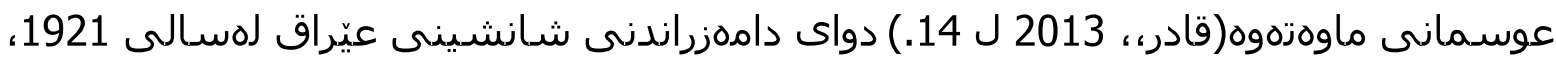

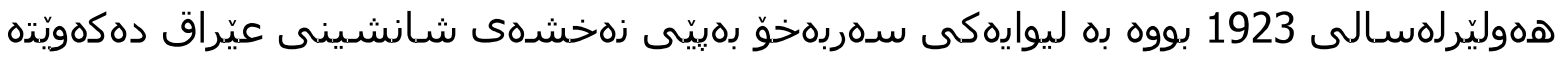

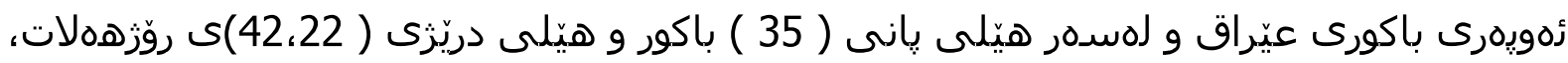

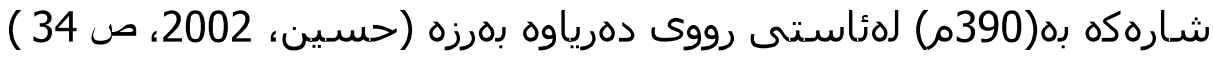

ليواى هذوليّر به ليواكانى موسل و كهركوك و سليّمانى دهوردراوه، ليواى موسل به به دورورى (

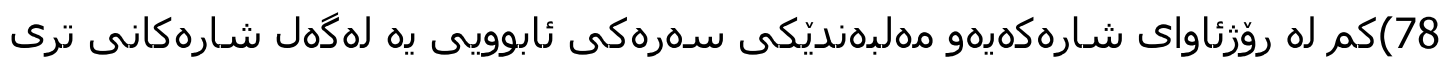

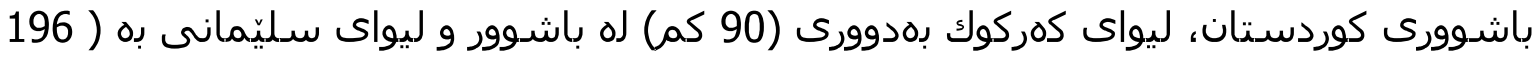

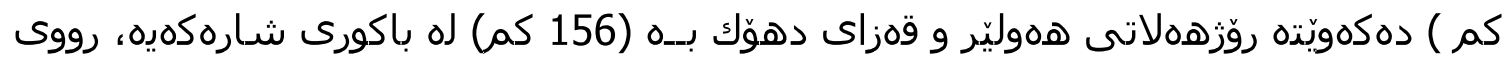

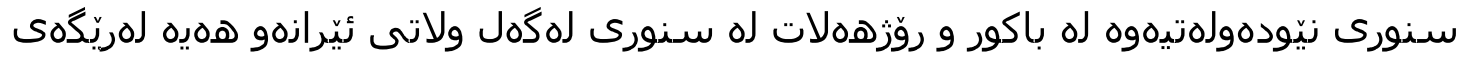

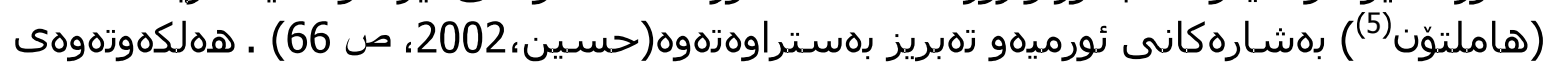

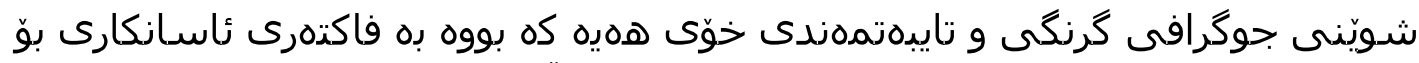

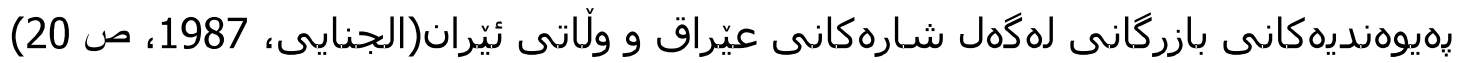

هذوليّر ئاوهذواى دهرياى ناوهراستى هذيه، لههاويندا گهرم و له زستان ساردو باراناوييه له

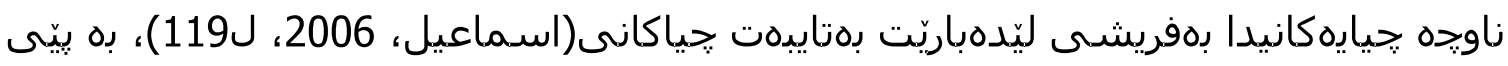

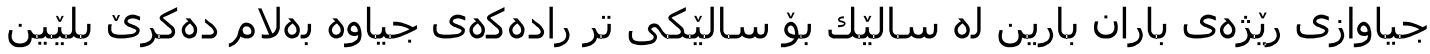

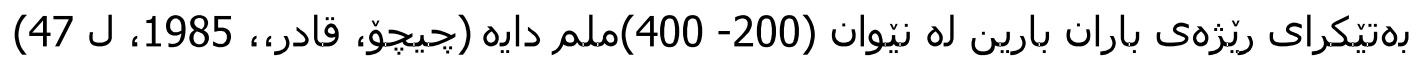

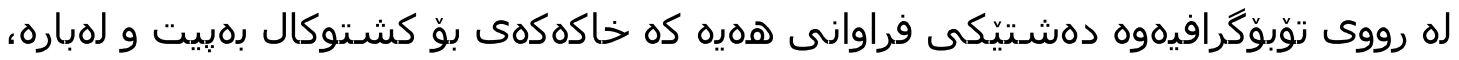

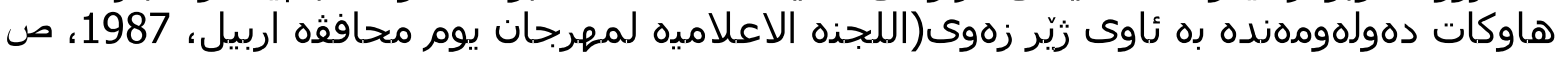

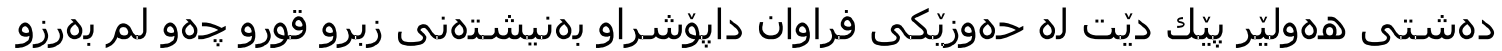

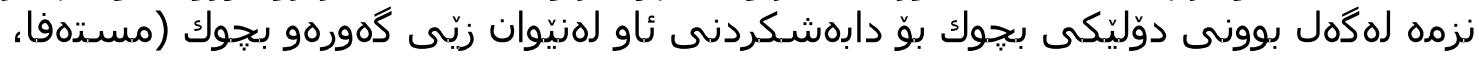

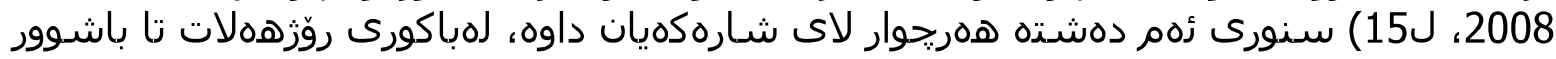

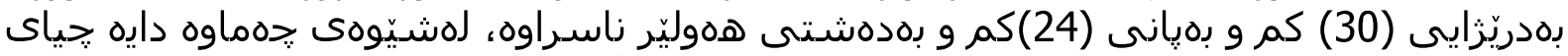

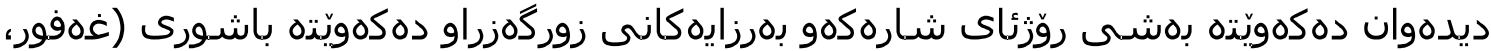

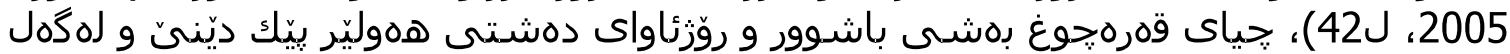

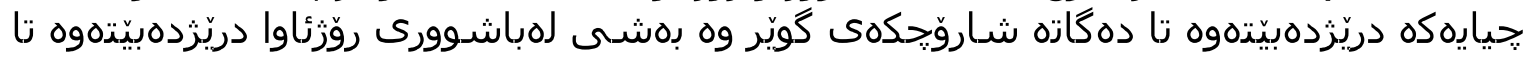

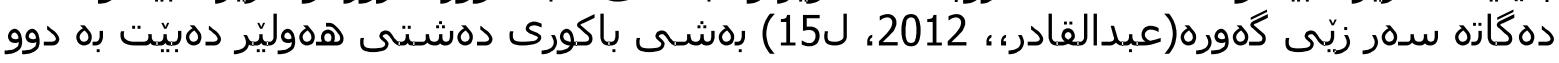

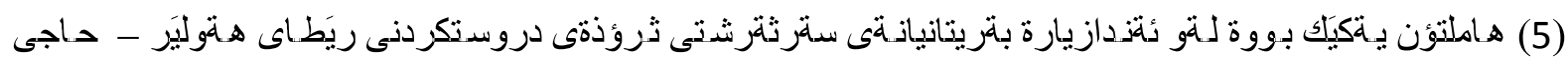

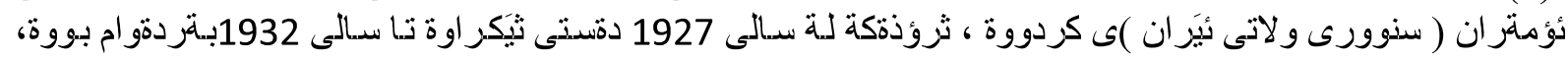

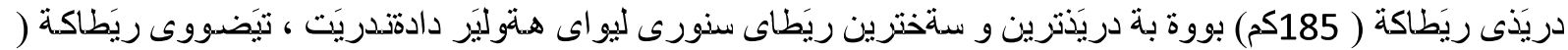

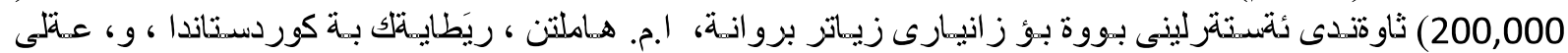

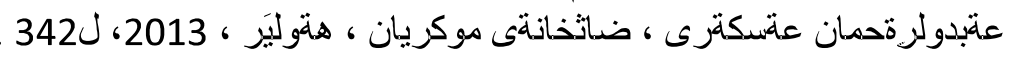

International Journal of Kurdish Studies Vol.5/1 (January 2019) 


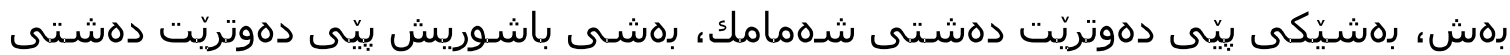

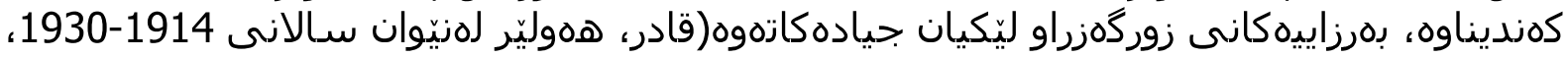

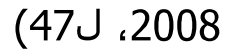

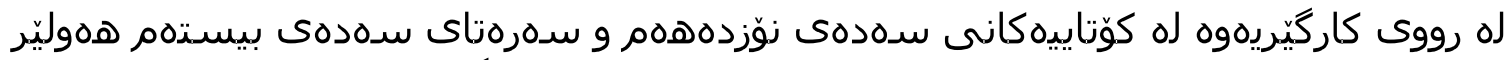

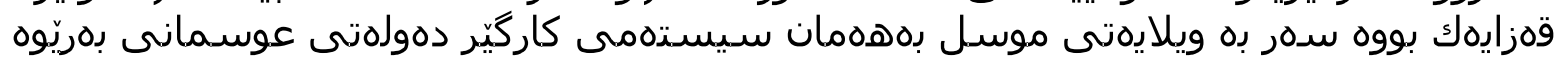

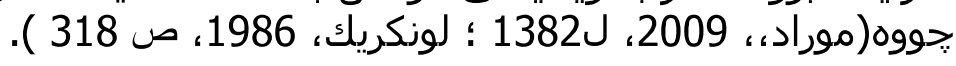

\section{دووهم / كشتوكالّ و بازركانى :}

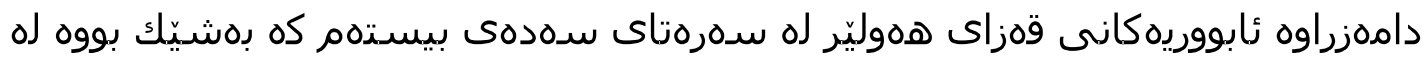

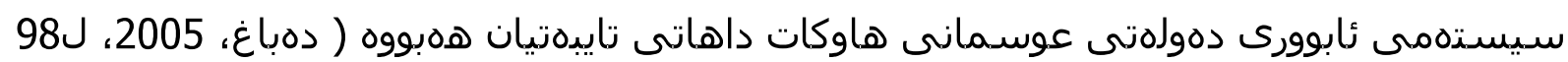

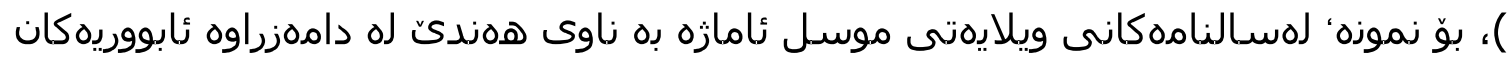

سهنتهرى قهزا كراوه وهك تيّدا هاتووه "لهسالى (

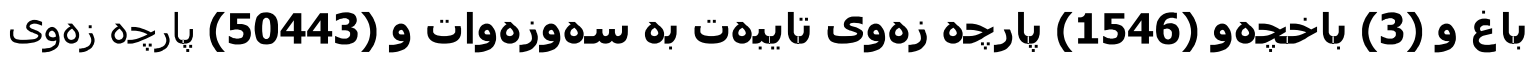

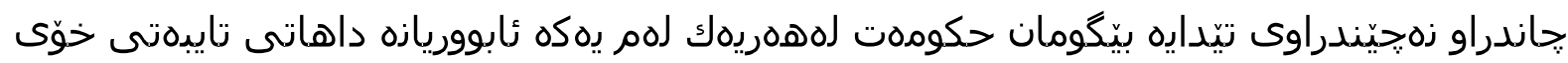

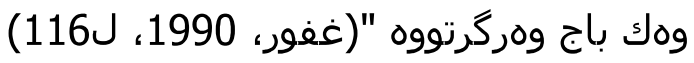

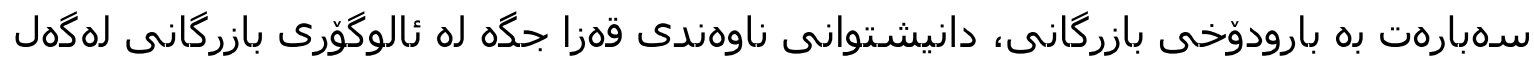

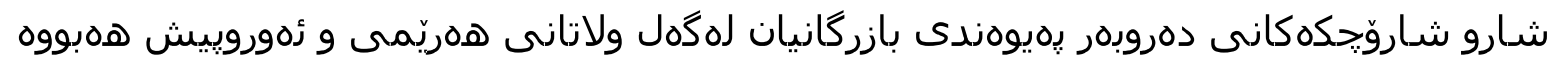
له ولاتى ئيّران وكوّميانيا بيانيهكان وهوك كوّميانيان

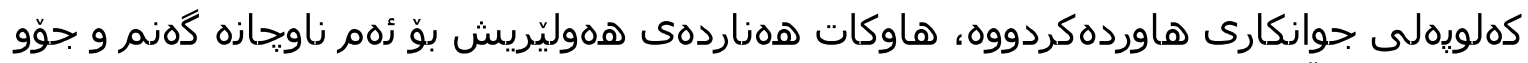

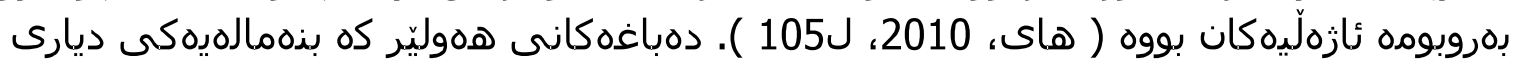

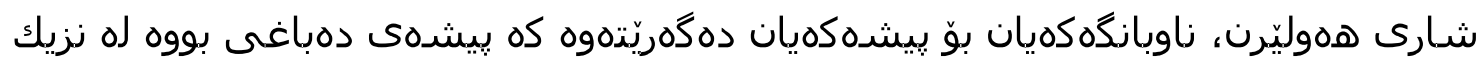

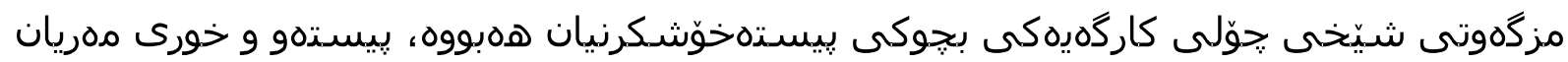

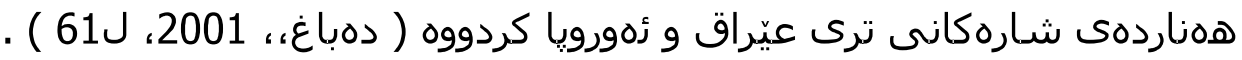

دهربارهى بارودوّخى بِيشهذهى قهزاى هذوليّريش هاوشيّوهى تهواوى له ناوِّه كورديهكان

بهشيْوهيه دهى

گشتى دواكهوتوو بووه، زٔهو دروستكراوازهى هذبوون زياتر بوّ يركردزهوهى بِيّداوستيه ناوخوَييهكان

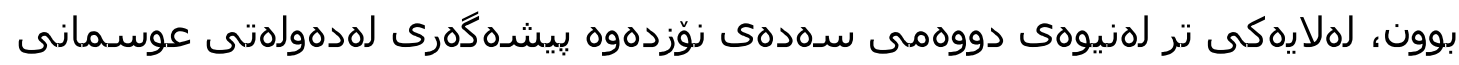

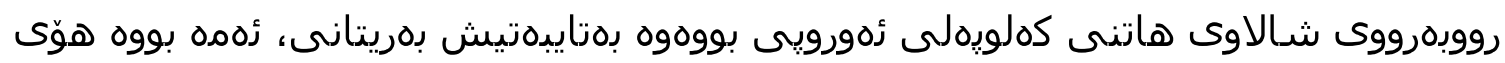

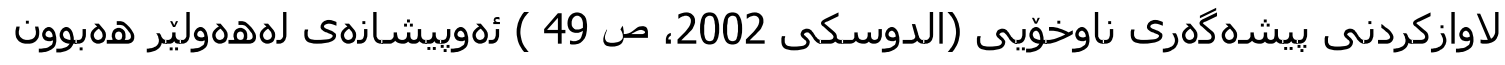

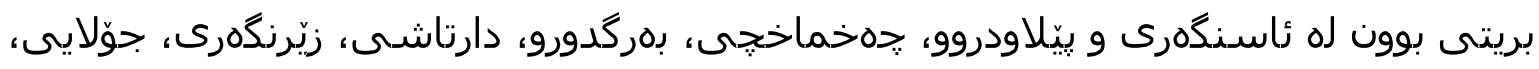

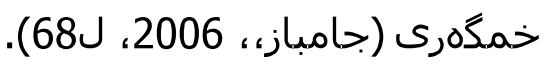

أ / بههoمه كشتوكاليهكان :

: 1 


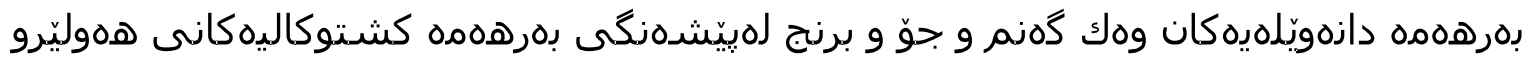

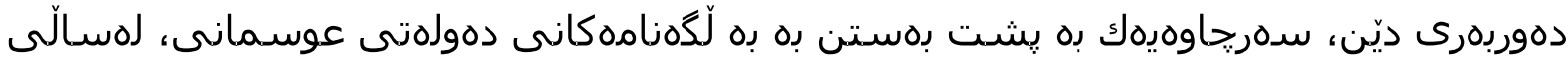

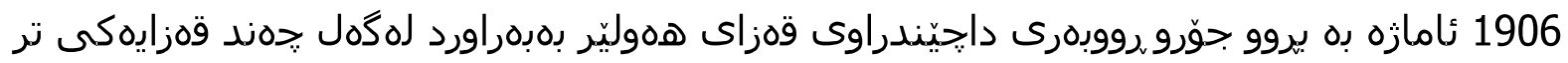

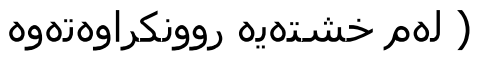

( Marufoglu 1998، p186 )

رووبهرى داحيّندراوى كَزم و جوّ له قهزاى هنوليّرو جهند قهزايهكى تر

ل المسالى 1906

\begin{tabular}{|c|c|c|c|c|c|c|}
\hline برى كيله برههم & دوونم & برى كيله برههم & دووبهر بـ & 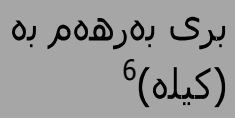 & دوونم & قهزا \\
\hline & برنج & & جوٌ & & كانم & \\
\hline 8000 & 460 & 24.000 & 50.000 & 480.000 & 100.000 & هذوليّر \\
\hline ------- & ------- & 24.000 & 4000 & 50.000 & 10.000 & رواندز \\
\hline ------- & ------- & 90.000 & 15.000 & 60.000 & 20.000 & كوّيسنججق \\
\hline 16.000 & 1.600 & 90.000 & 15.000 & 180.000 & $30 ، 000$ & ر رانيه \\
\hline
\end{tabular}

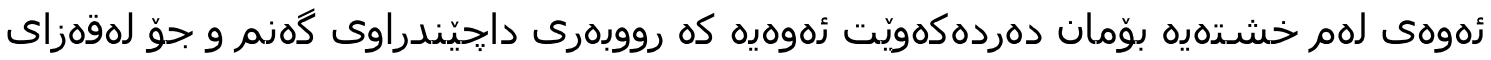

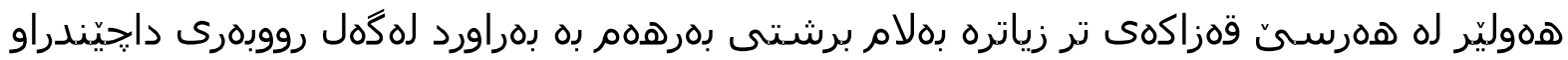

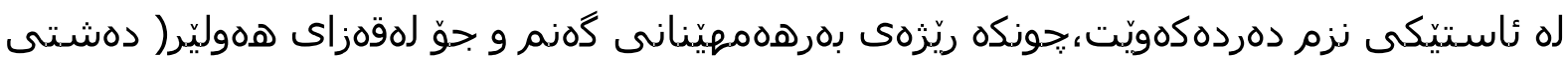

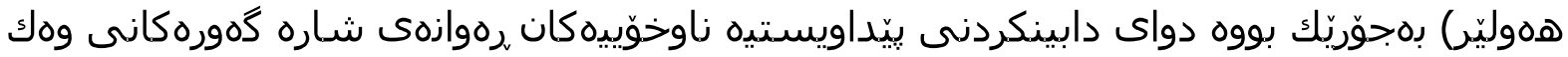

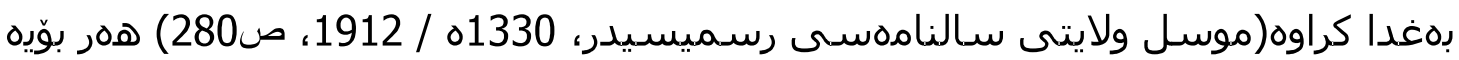

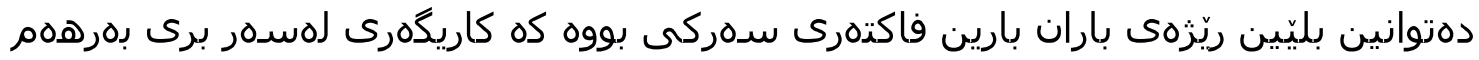

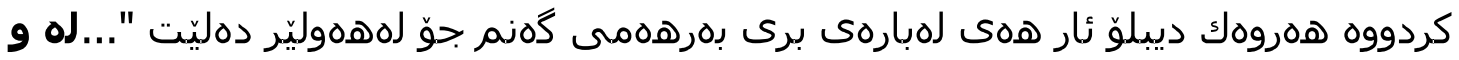

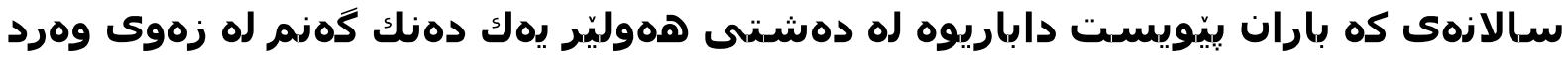

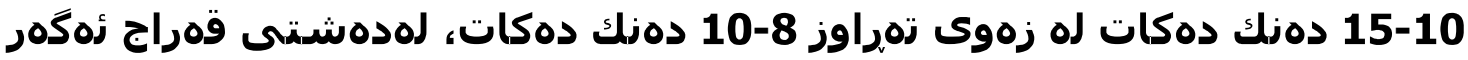

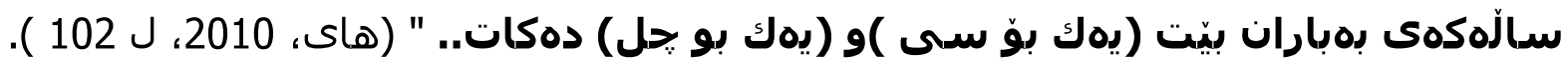

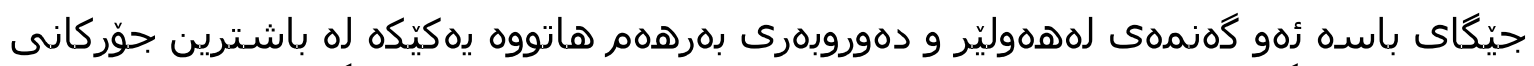

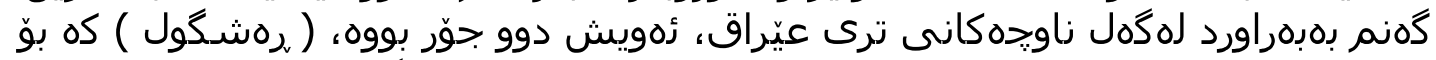

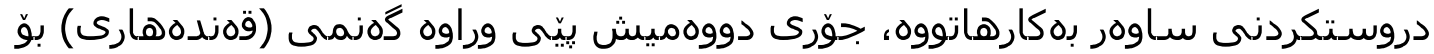

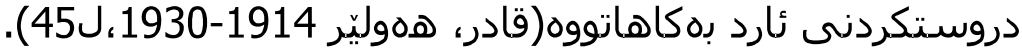

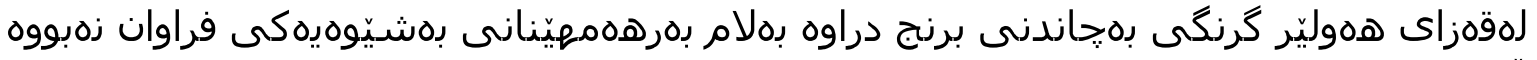

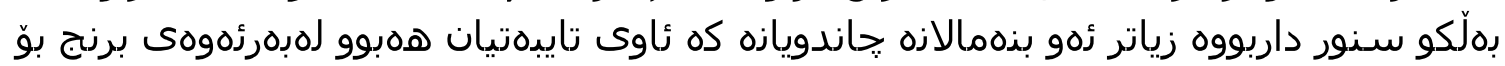

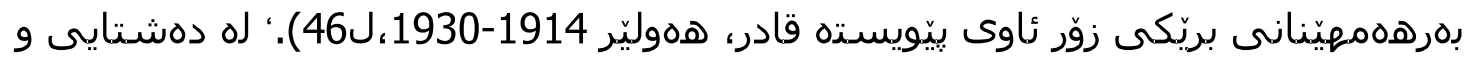

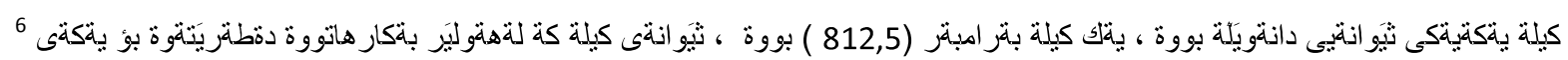

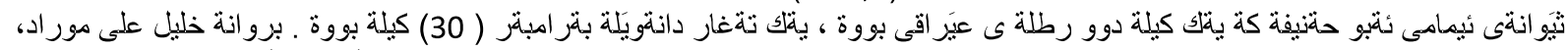

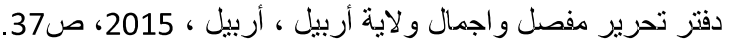




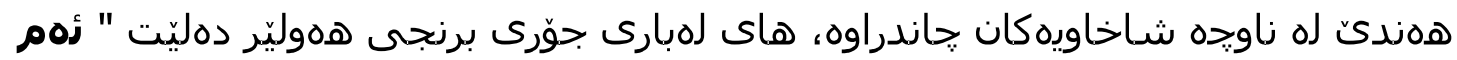

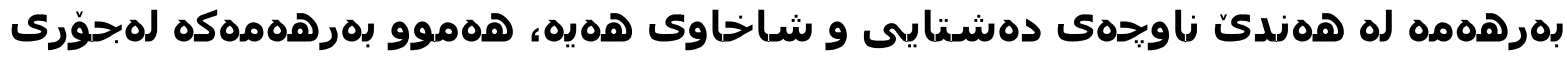

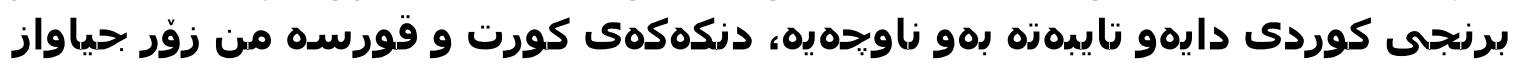

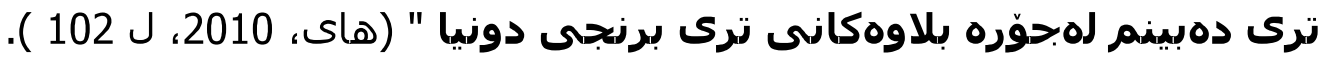

\section{2-}

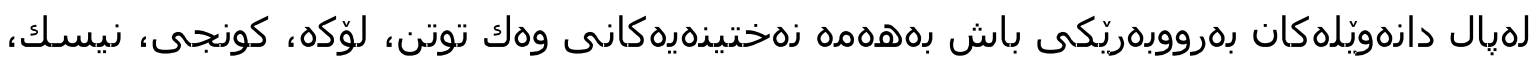

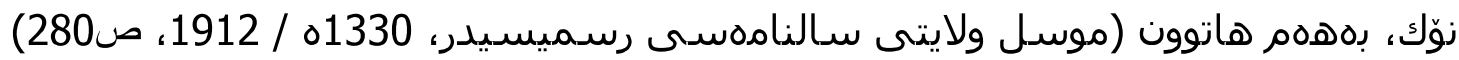

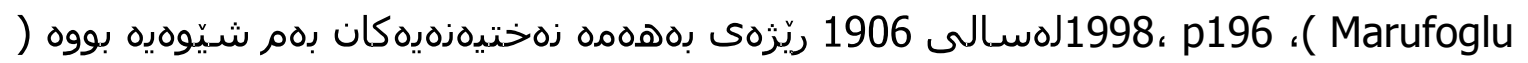

بهرههمه زهختيفهيهكان له قهزاى هذوليّرو جهزند قهزايهكى تر لهسالى

1906

\begin{tabular}{|c|c|c|c|c|c|c|}
\hline \multirow{3}{*}{ بره هوق برةههرم } & رووبهر به & \multirow{3}{*}{ 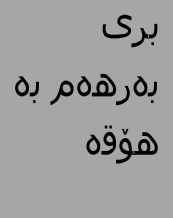 } & روפبهر به & \multirow{3}{*}{ هروى برهرهذم به } & رووبهر به & \multirow[t]{3}{*}{ قهزا } \\
\hline & دوّنم & & دؤمر & & دوْنم & \\
\hline & توتن & & كونجى & & لِوَكه & \\
\hline ------- & ------ & $1 ، 600$ & 160 & 50.000 & 2.000 & هذوليّر \\
\hline $120 ، 000$ & 5.000 & $5 ، 000$ & 200 & 35.000 & 800 & رواندز \\
\hline 30.000 & 2000 & 7.500 & 25 & $100 ، 000$ & $5 ، 000$ & كوّيسـنجق \\
\hline $80 ، 000$ & 30.500 & -------- & ------- & 50.000 & 2.000 & رانيه \\
\hline
\end{tabular}

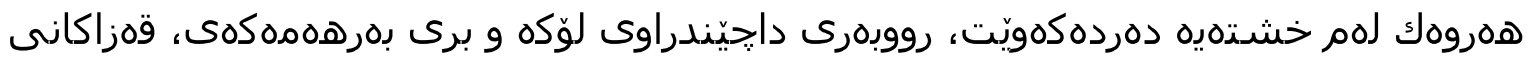

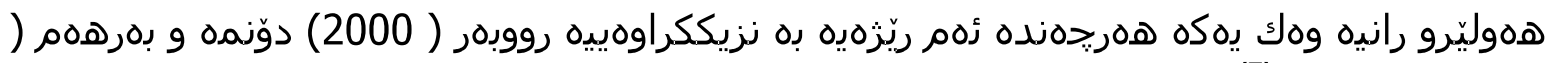

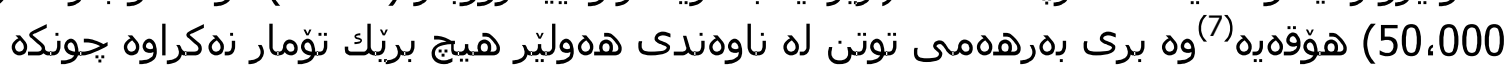

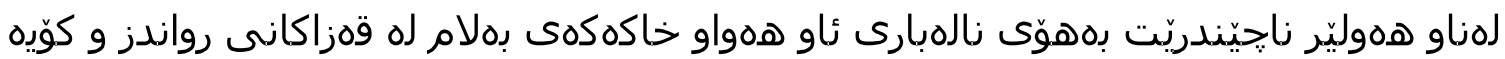

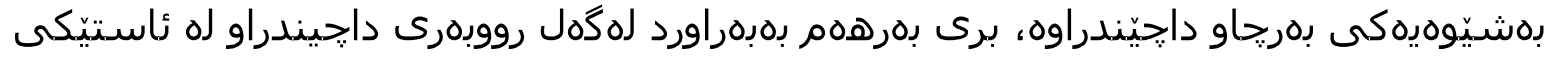

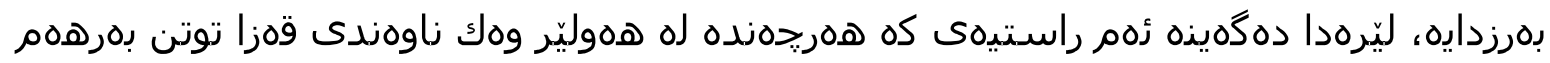

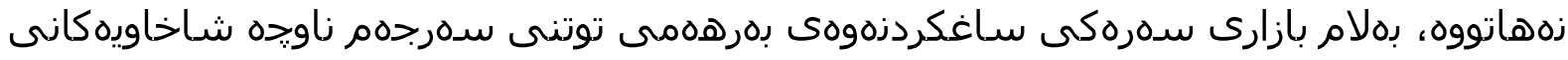

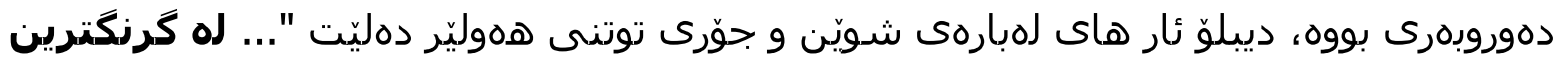

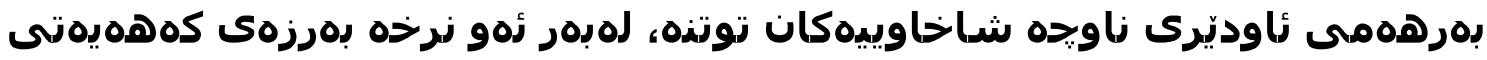

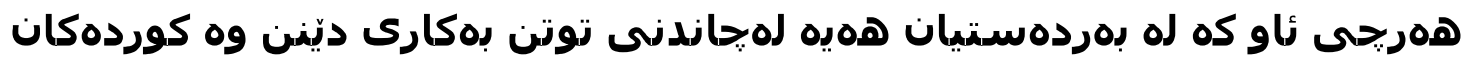

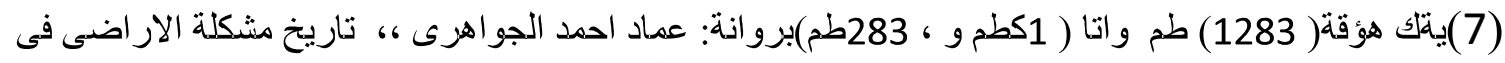

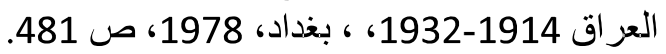




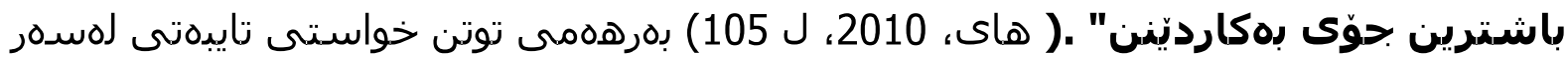

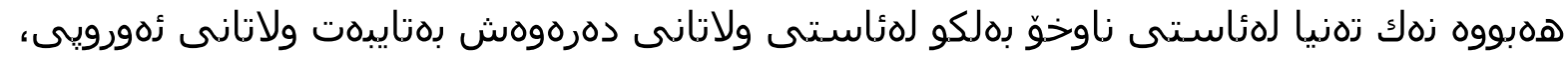

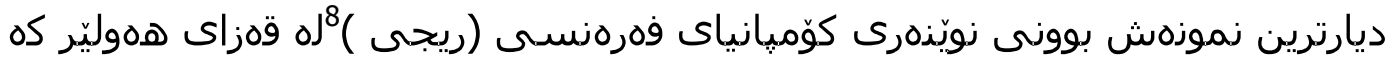

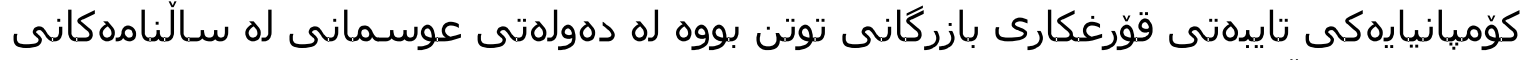

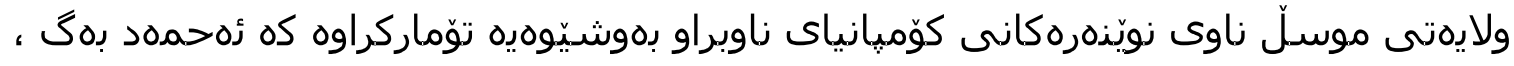

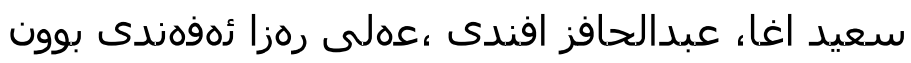

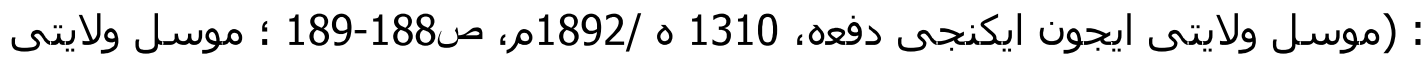

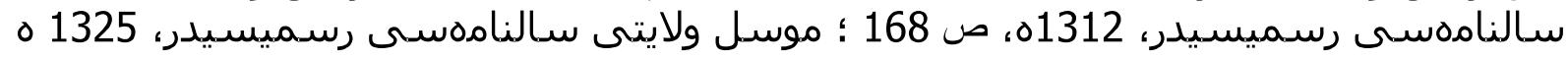

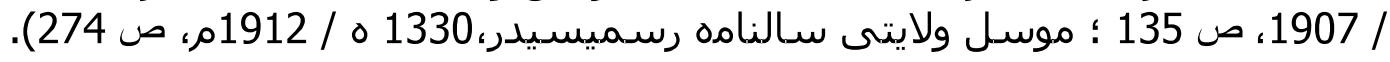
دهكريّت بليّين سهبارِ

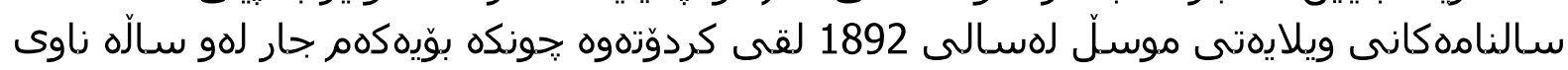

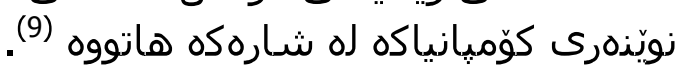

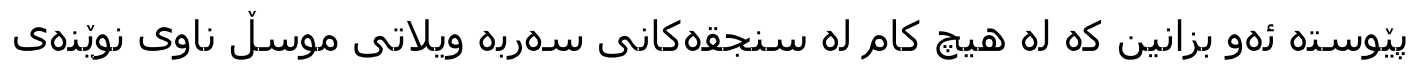

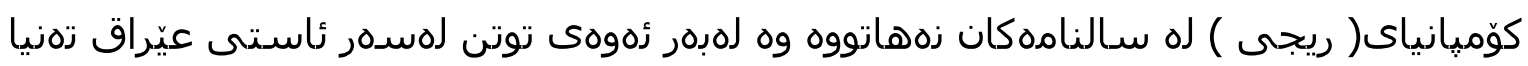

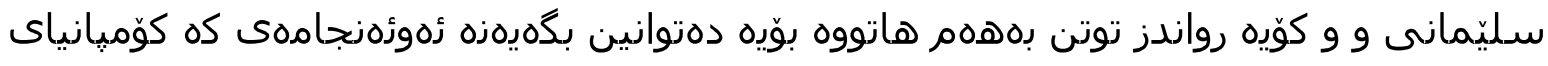

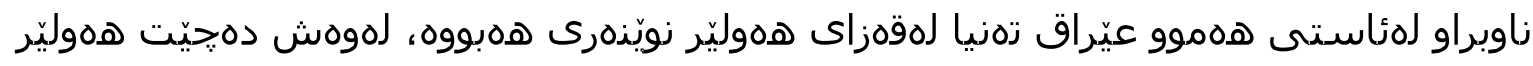

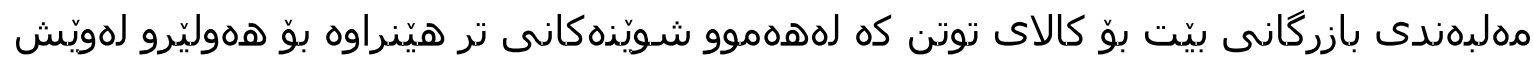

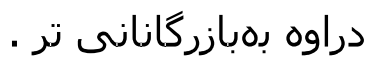

\section{3- 30روبوومى ميوه :}

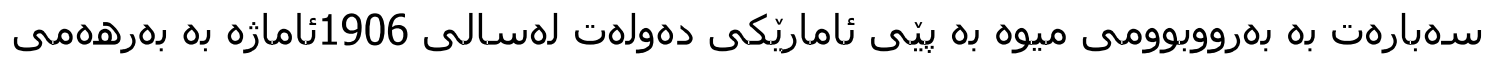
(Marufoglu

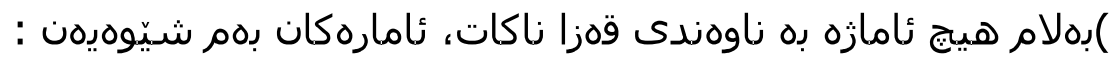

\begin{tabular}{|c|c|c|c|c|c|c|}
\hline برى هورَهر & برى هوَّرة بهرم & بره هوّوَه برهذم & برى هوّورة بههةم & برى بوروههمر به & برى هوّةرهذم & قهزا \\
\hline باوى & هذنجير & هذرمى & سـيْو & قوّغ & كَوِيز & \\
\hline
\end{tabular}

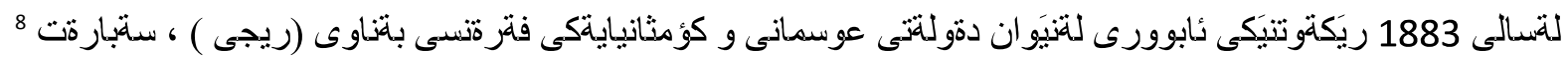

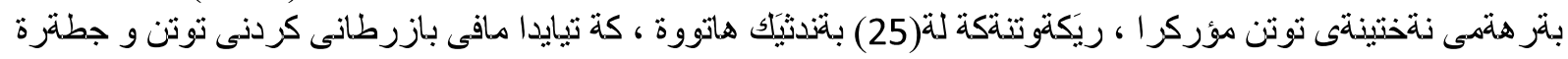

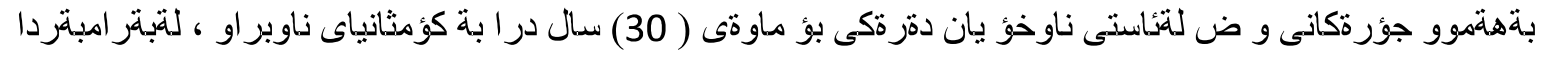
كؤمثانياكة دةبوو برى (

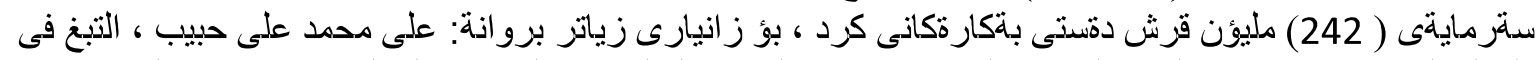

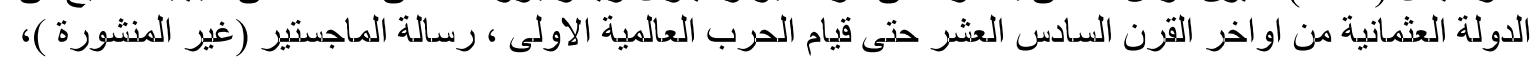

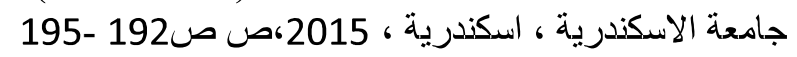

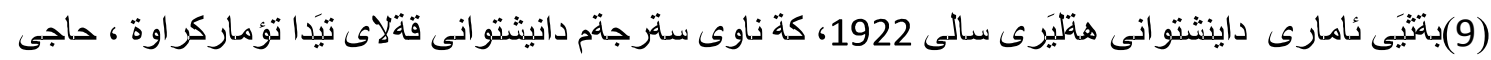

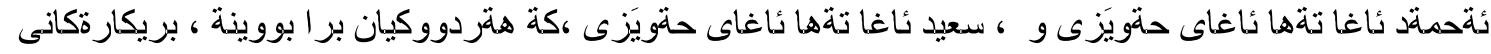

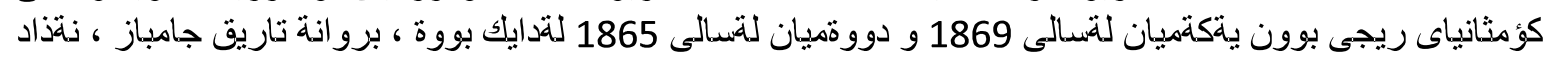

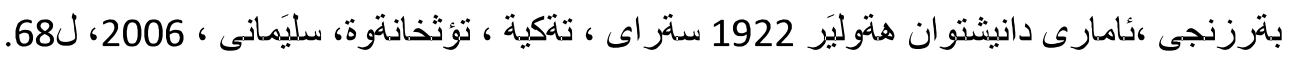

International Journal of Kurdish Studies Vol.5/1 ( January 2019) 


\begin{tabular}{|c|c|c|c|c|c|c|}
\hline ------- & -------- & -------- & ---------- & -------- & ------- & هذوليّر \\
\hline ------- & 40.000 & 3000 & 5000 & 2000 & 75.000 & رواندز \\
\hline 4000 & 5000 & 5000 & 5000 & $20 ، 000$ & 200.000 & كوَيسـنجق \\
\hline ------- & -------- & 10.000 & 15.000 & $20 ، 000$ & 40,000 & رانيه \\
\hline
\end{tabular}

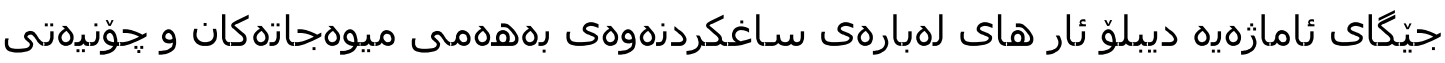

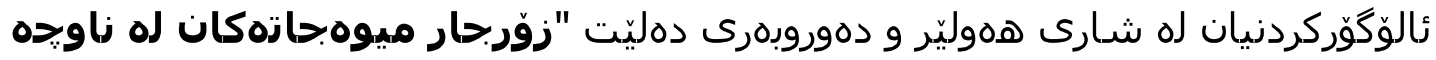

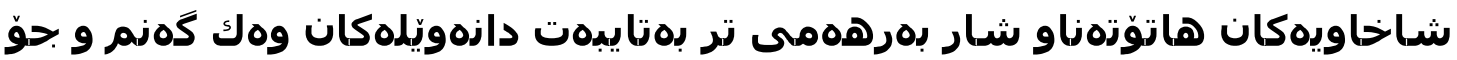

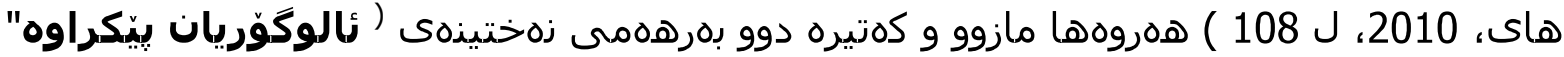

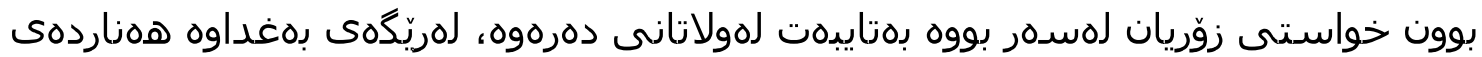

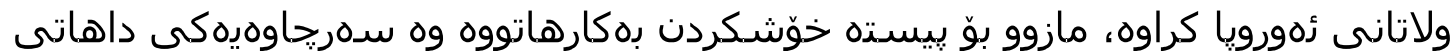

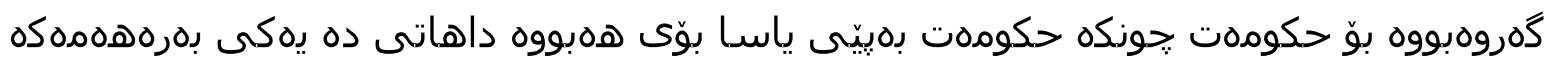

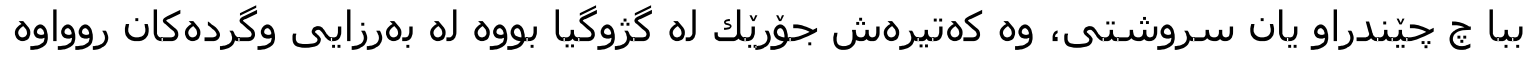

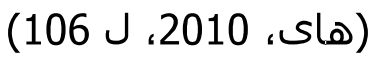

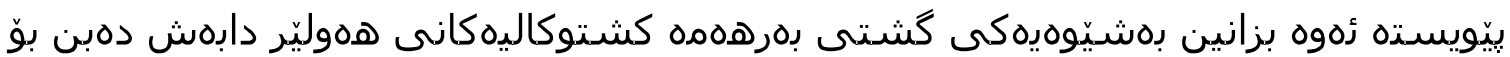

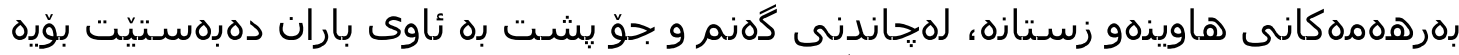

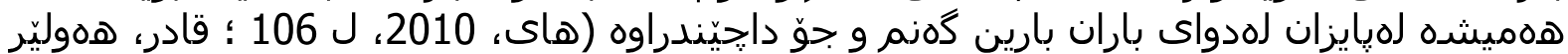

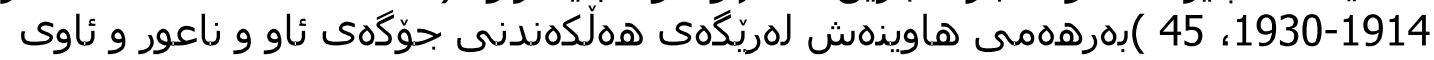

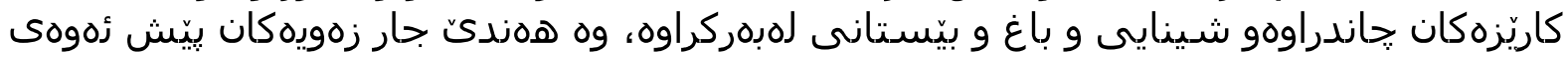

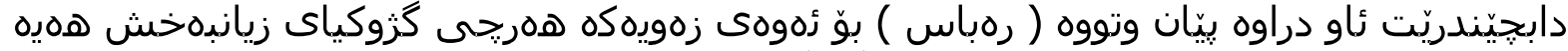

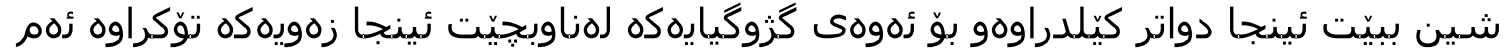

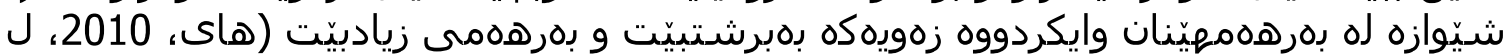

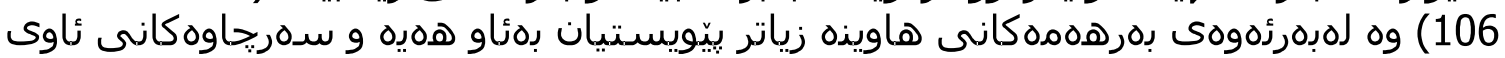

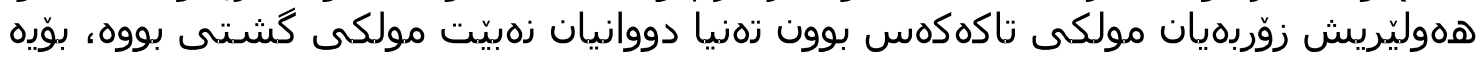

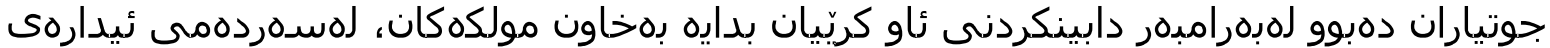

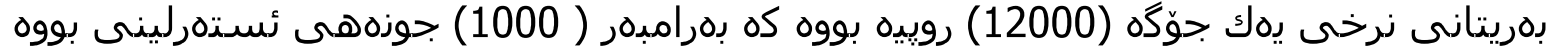

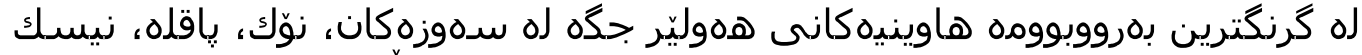

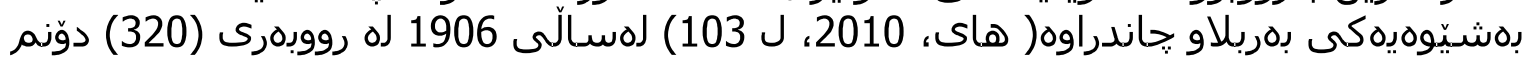

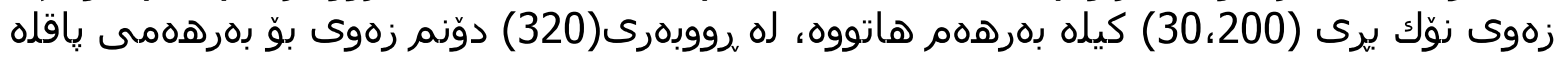

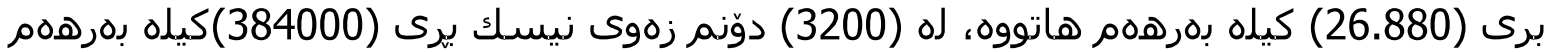

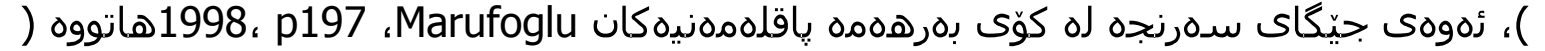

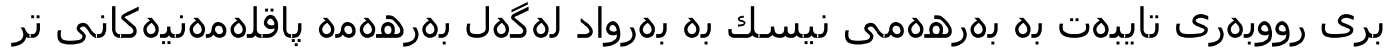

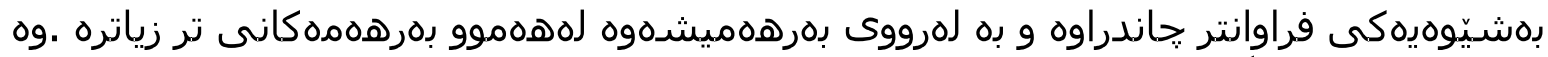

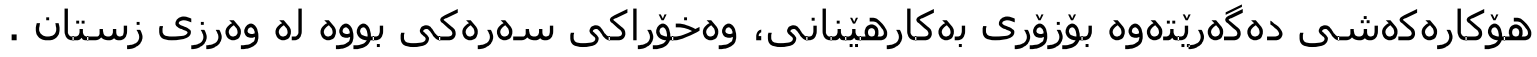

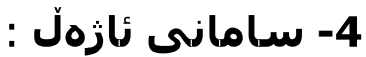

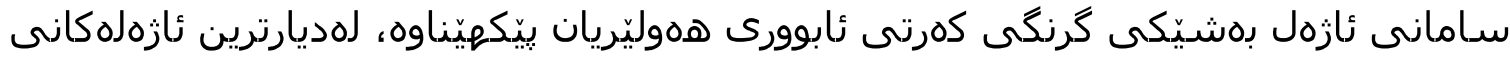

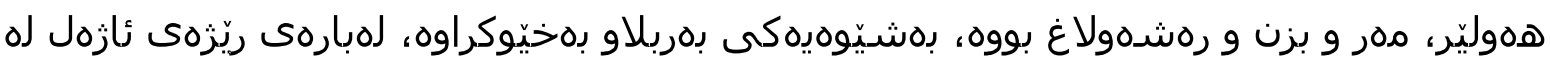

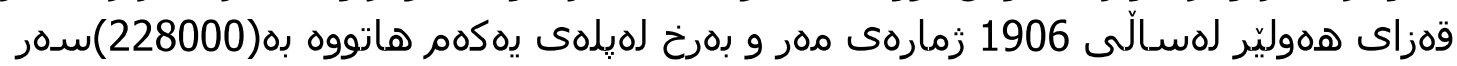


خهمليَندراوه و بزن به يِلهى دووهم (

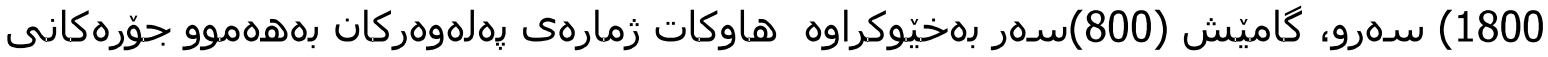

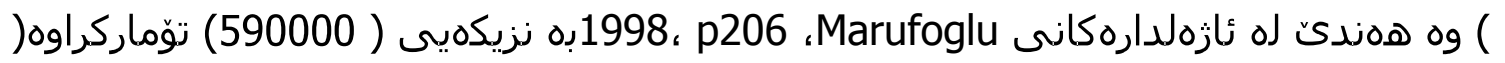

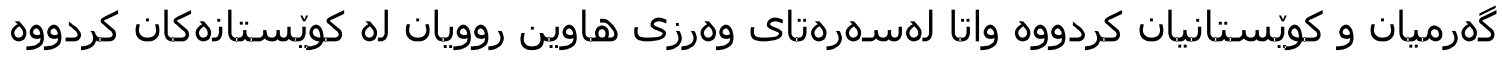

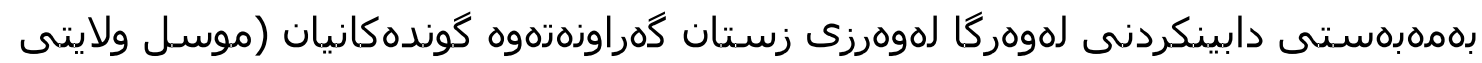

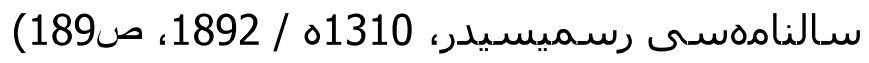

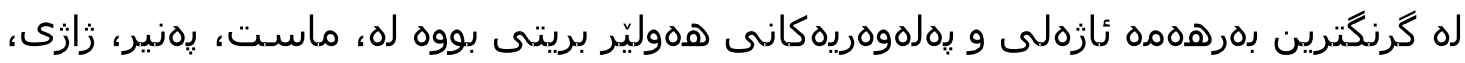

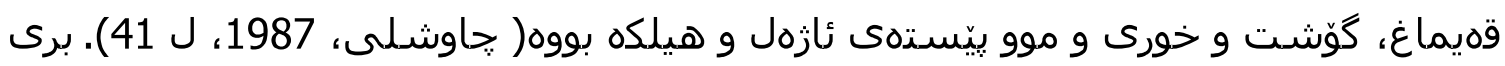

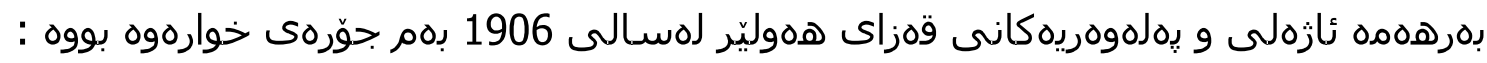
1998، p205) ،Marufoglu(

\begin{tabular}{|c|c|c|c|c|c|c|c|c|}
\hline هيَلكه & گِاميسشَ & 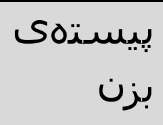 & مون & خورى & ك0ر0 & נֶסنير & شـير & بروهذرم \\
\hline 4200000 & 1000 & 2000 & 20000 & 250000 & 100000 & 150000 & 1000000 & بروى بوَّهر بره \\
\hline
\end{tabular}

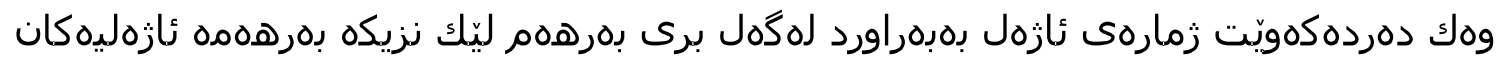

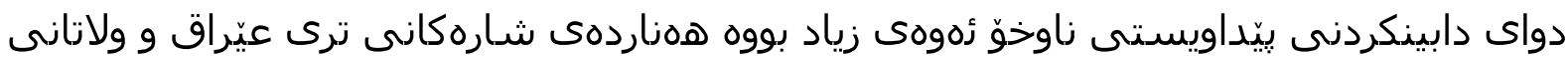

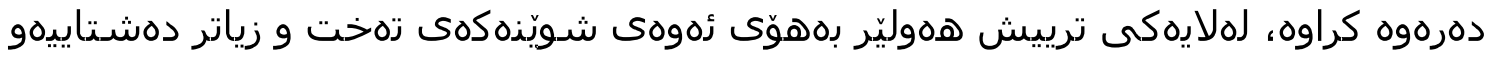

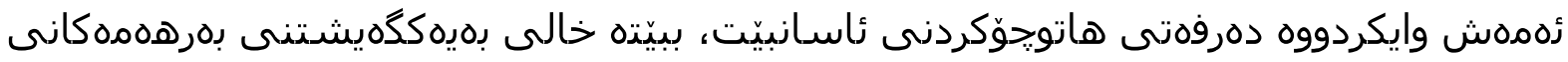

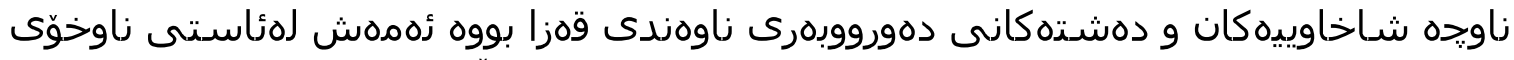

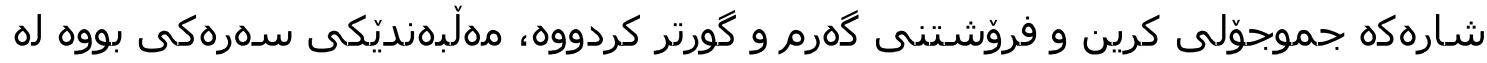

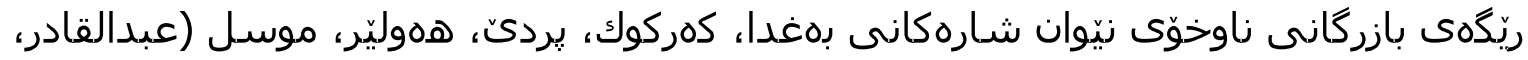

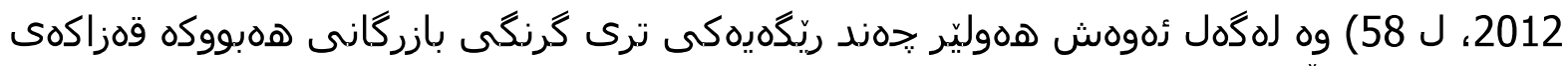

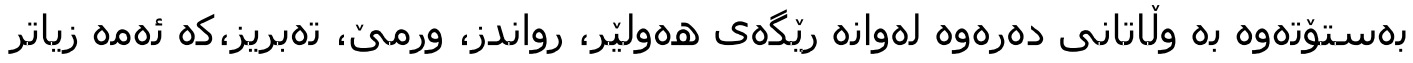

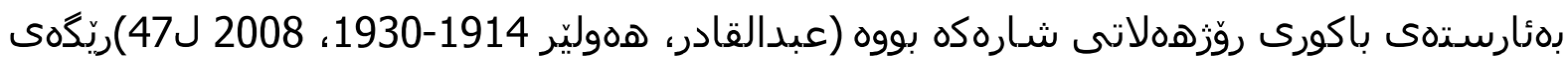

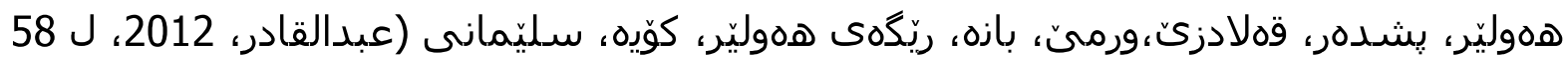

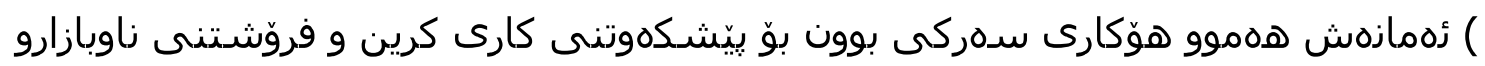

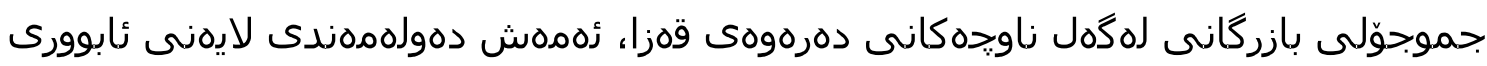

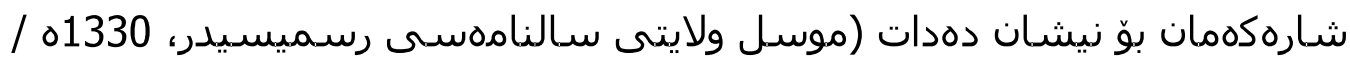

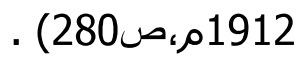




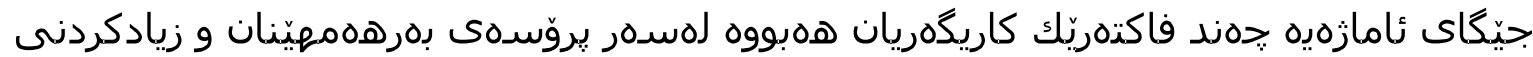

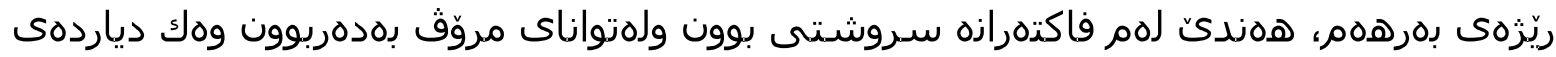

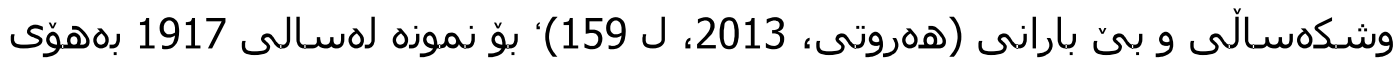

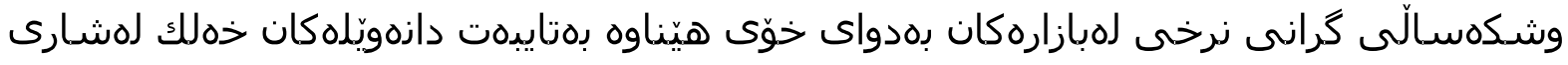

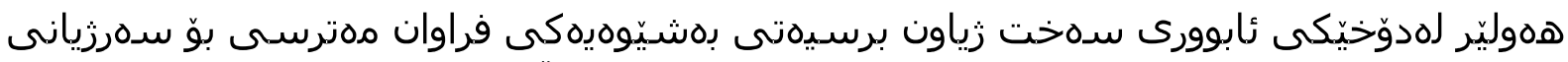

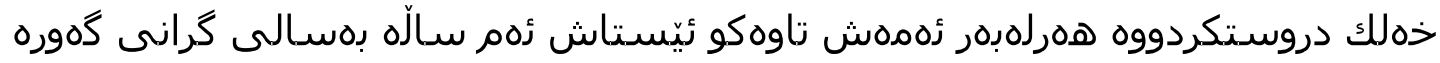

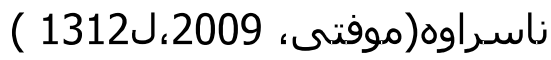

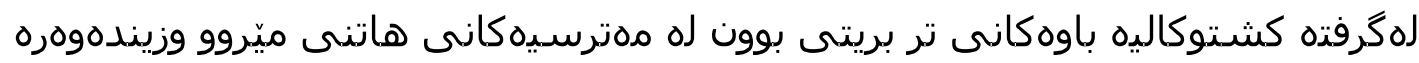

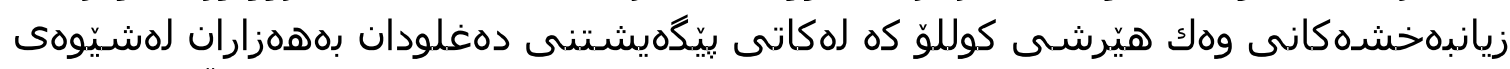

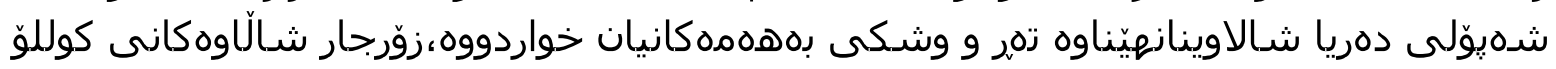

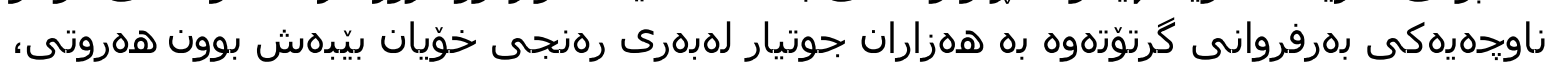

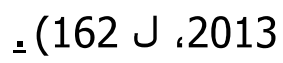

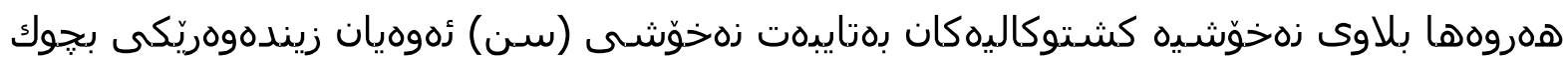

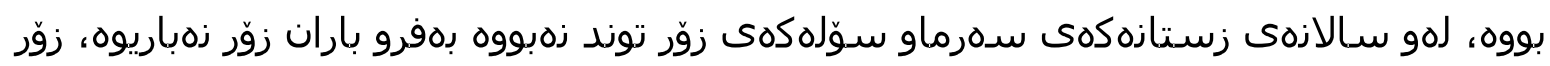

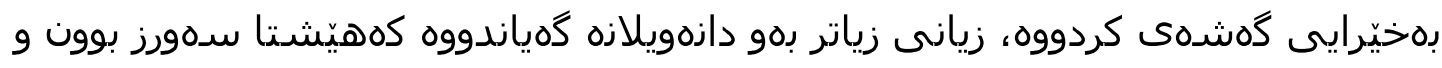

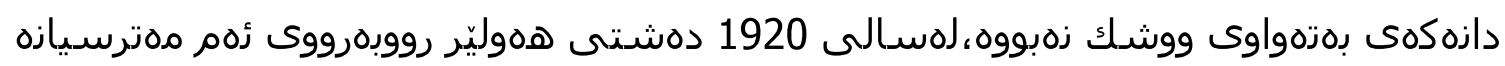

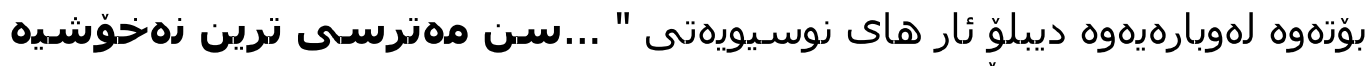

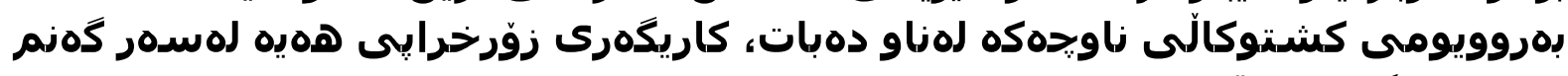

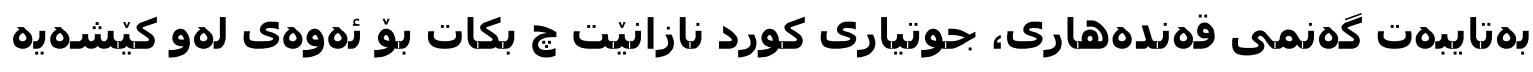

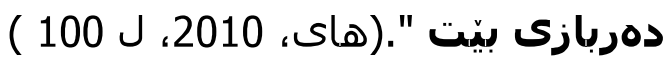

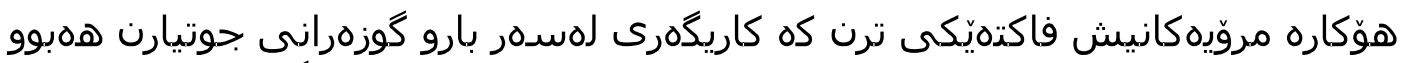

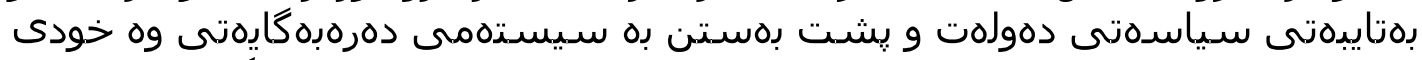

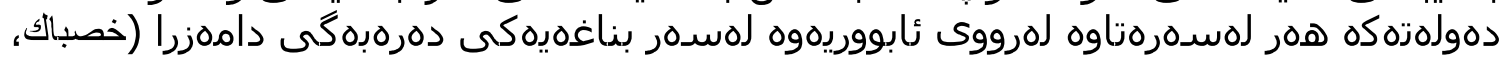

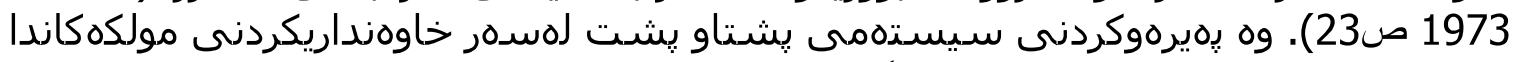

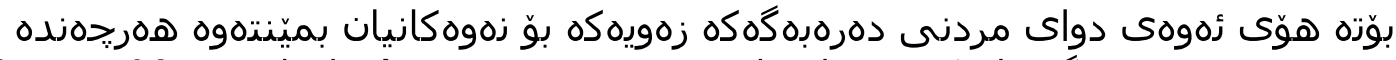

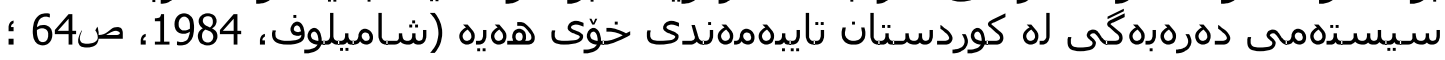

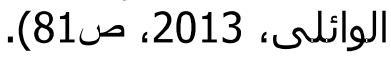

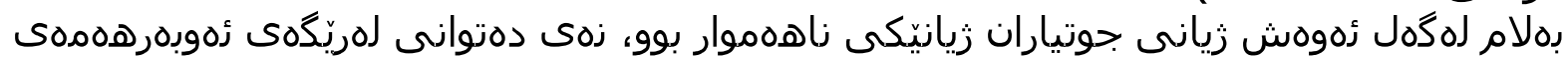

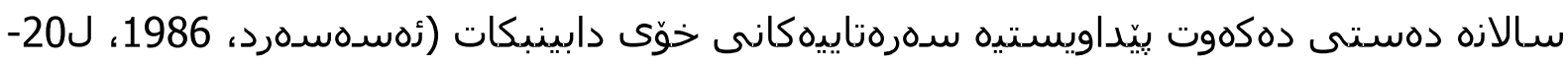

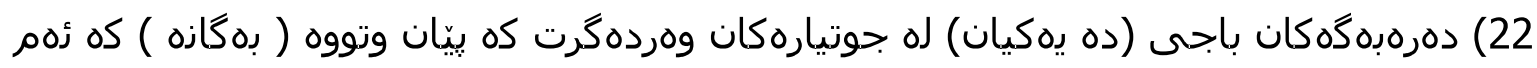

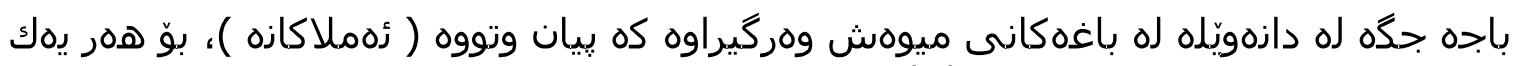

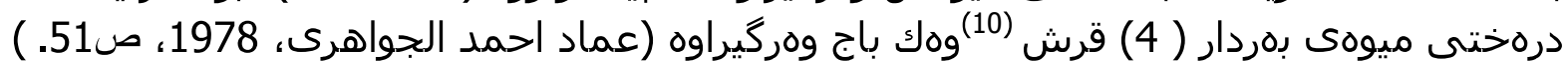

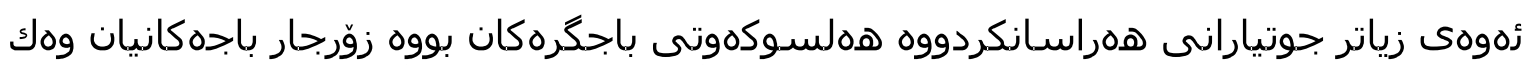

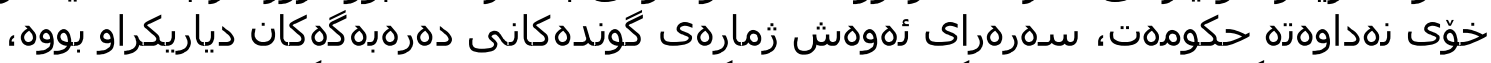

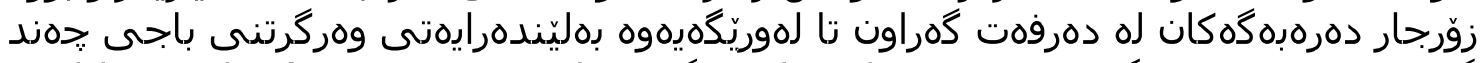

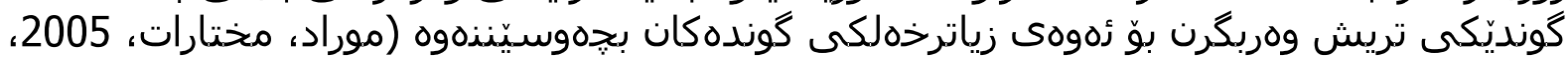

ص142-138

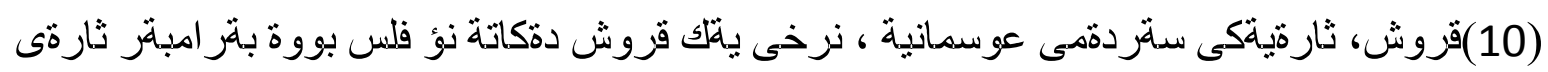

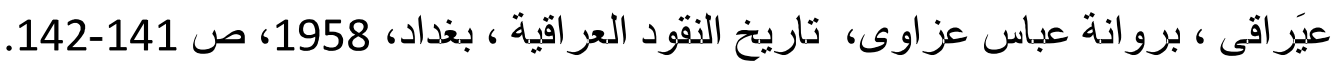




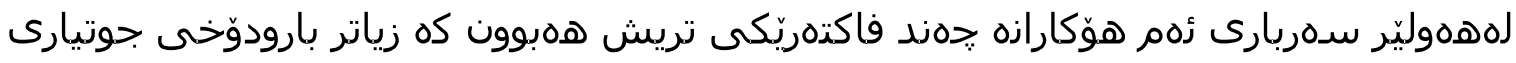

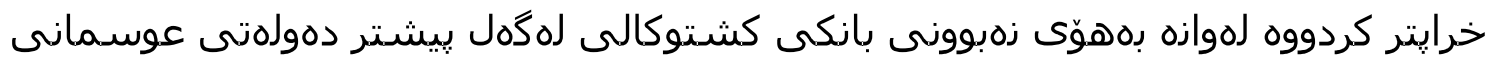

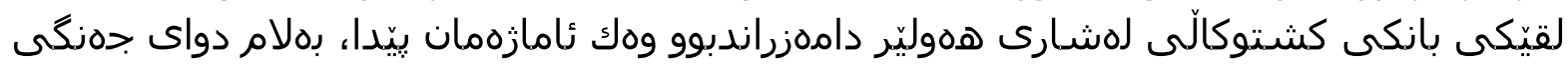

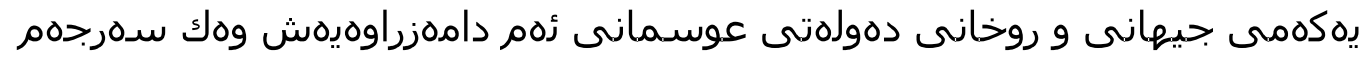

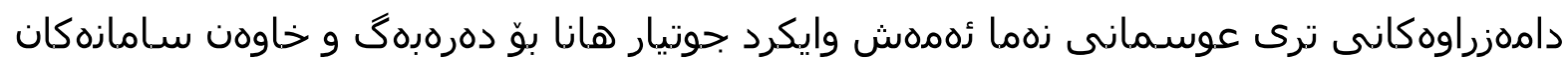

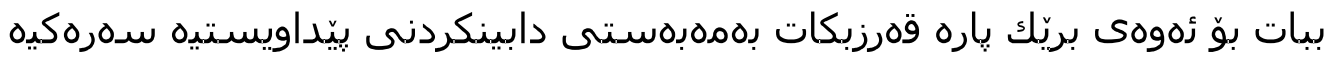

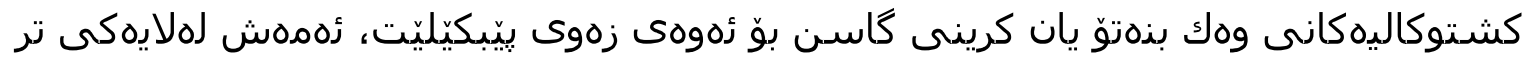

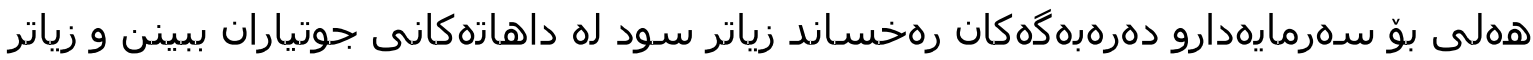

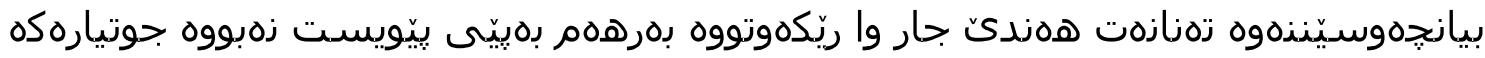

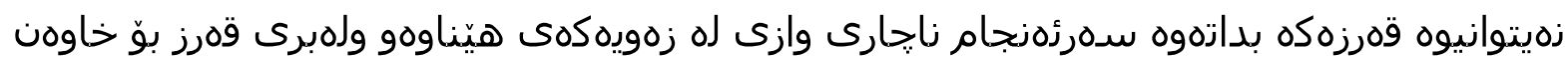

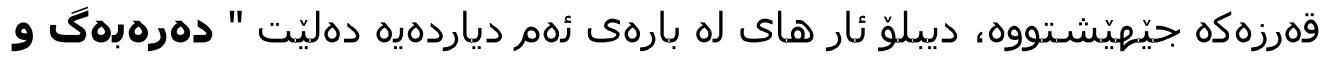

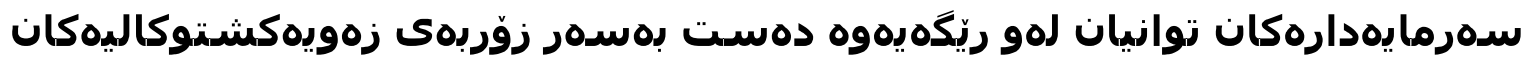
دابكرن " ( هاى، 2010 , ل108)

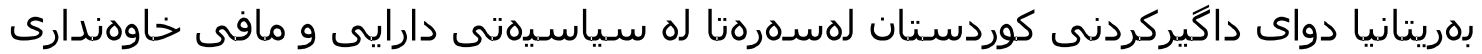

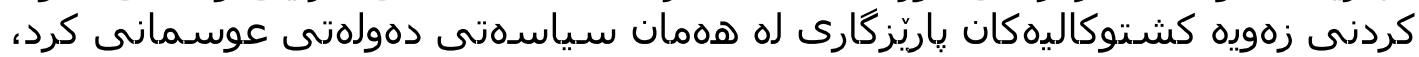

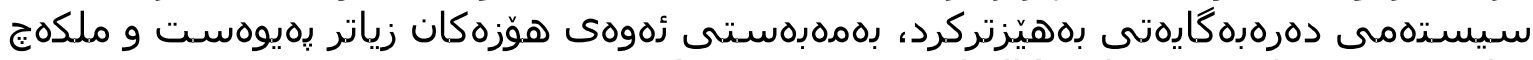

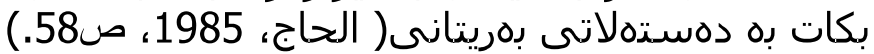

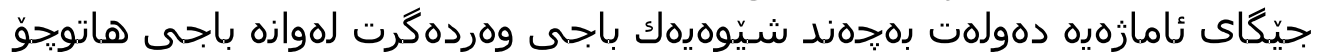

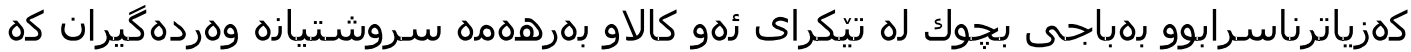

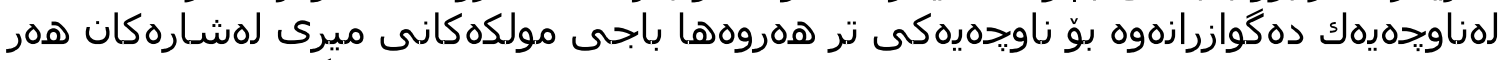

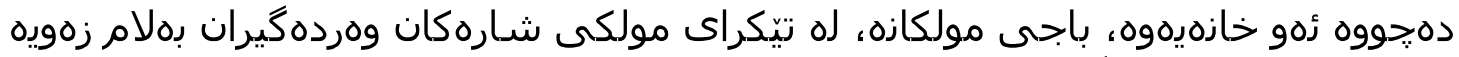

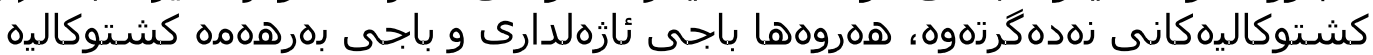

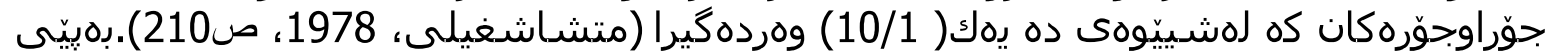

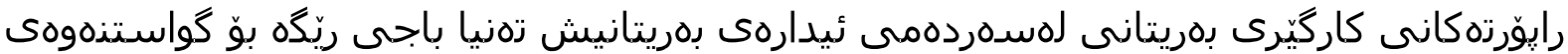
)

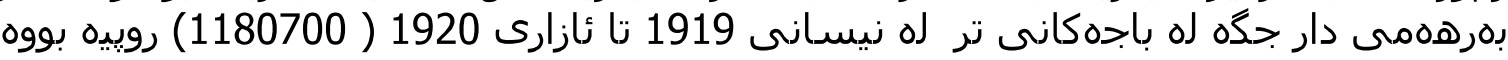
IRAQ ADMINISTRATION REPORRTS K. 1992. P18

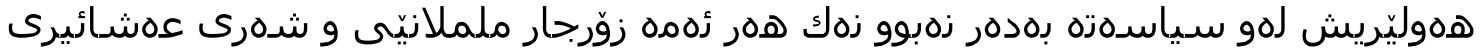

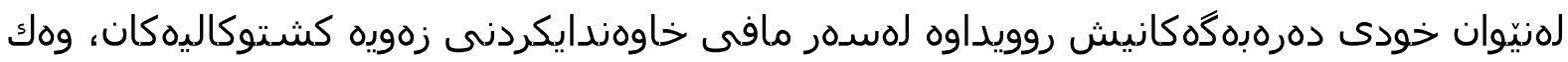

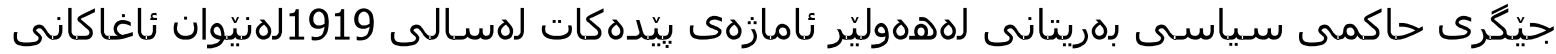

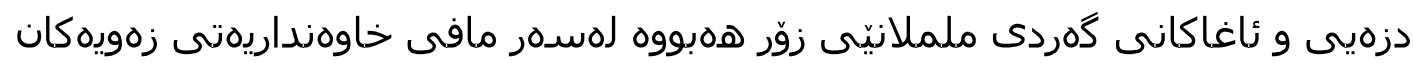

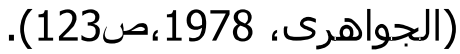

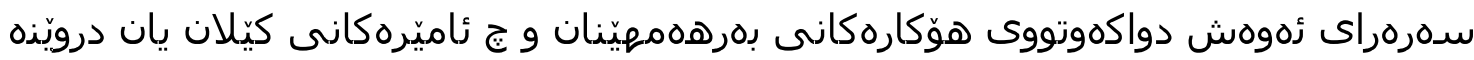

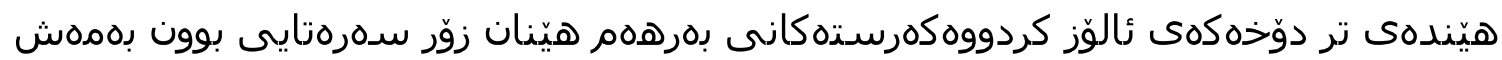

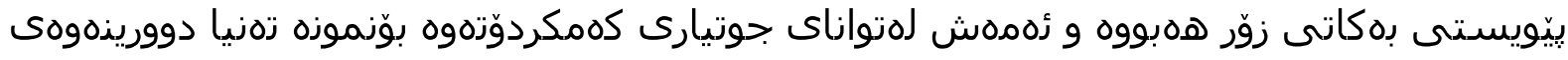

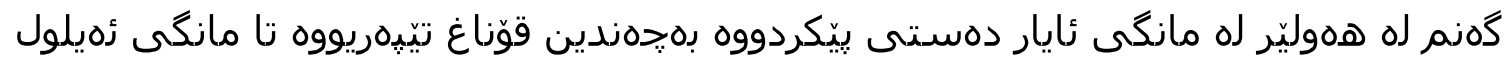

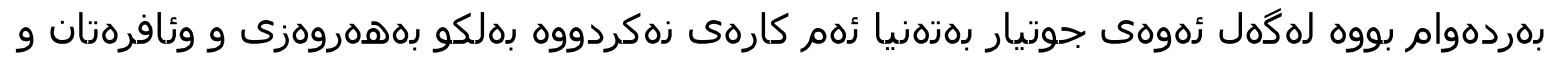

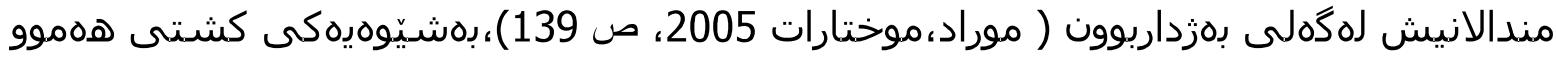

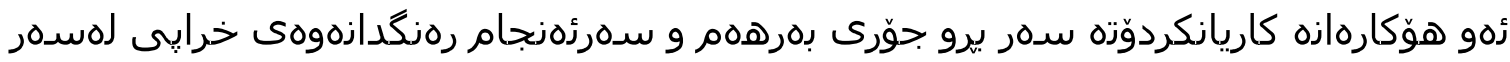

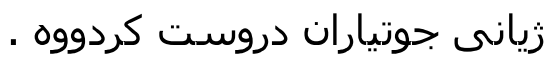




\section{سيّهم- سيستهمى دارايى :}

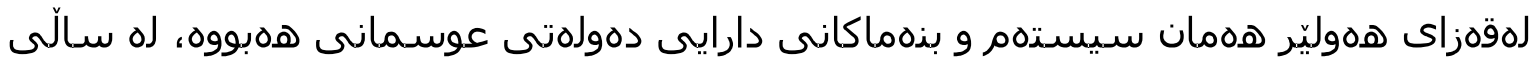

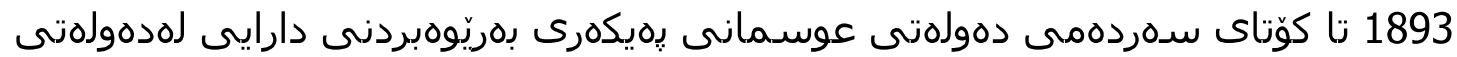

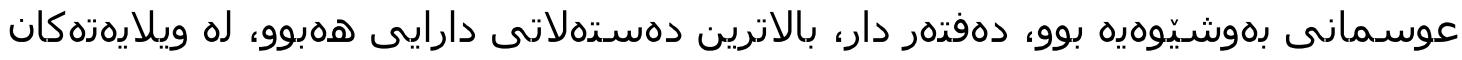

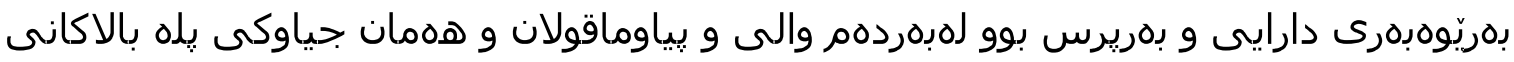

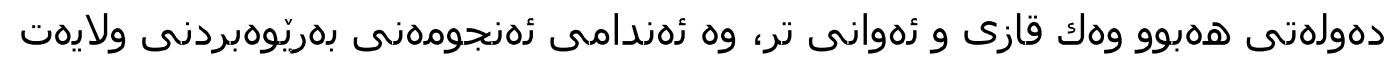

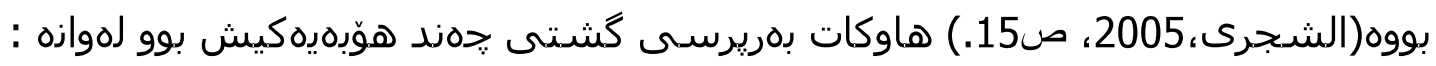

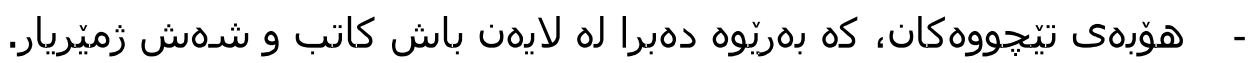

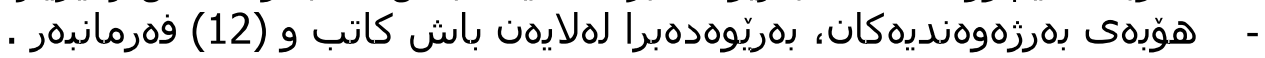

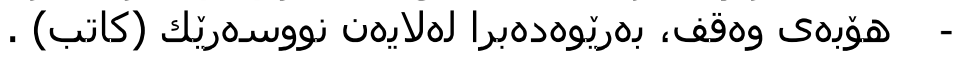

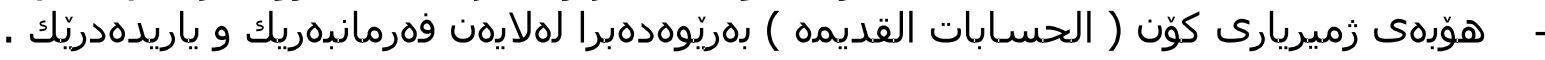

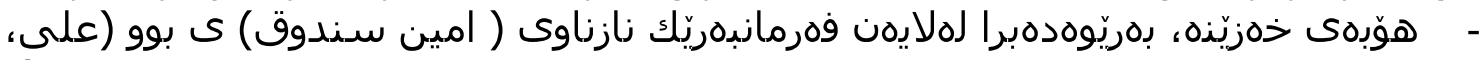

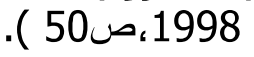

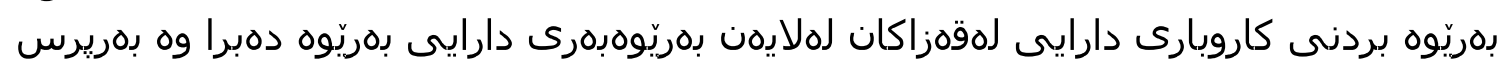

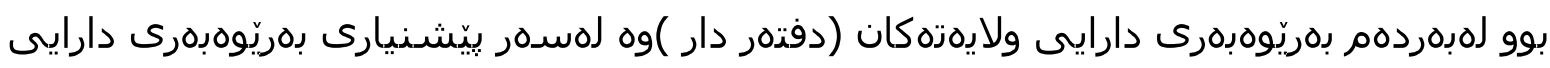

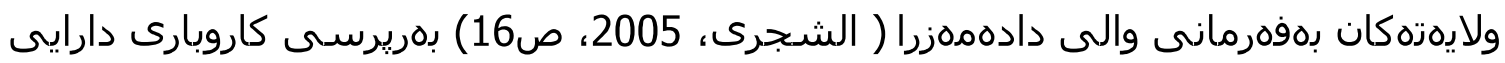

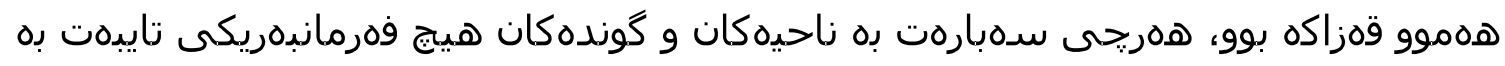

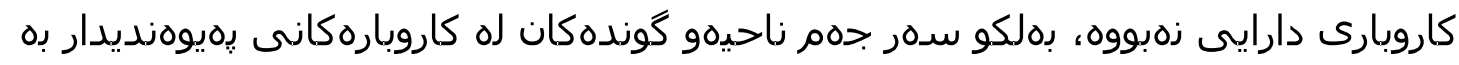

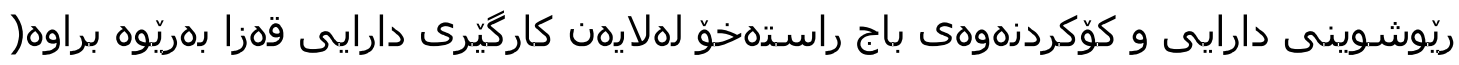

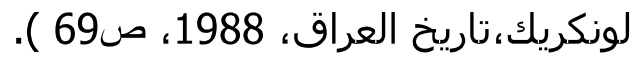

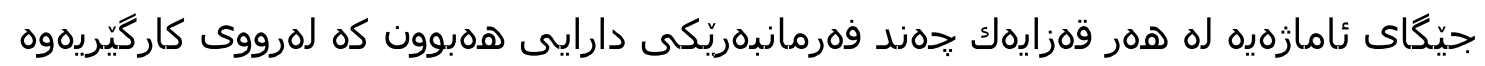

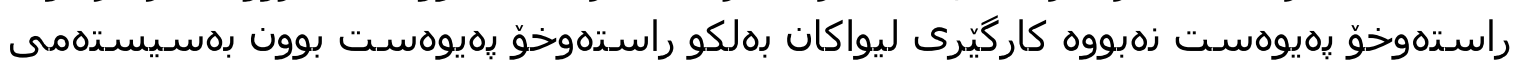

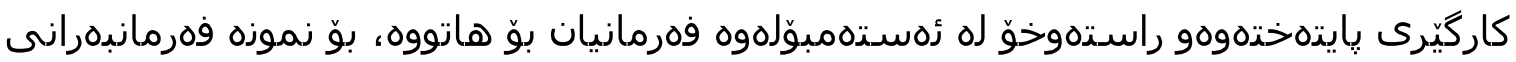

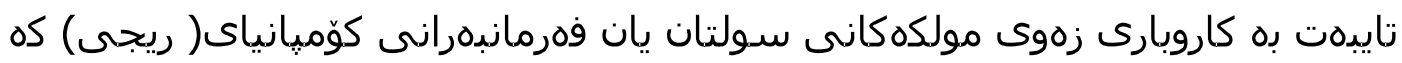

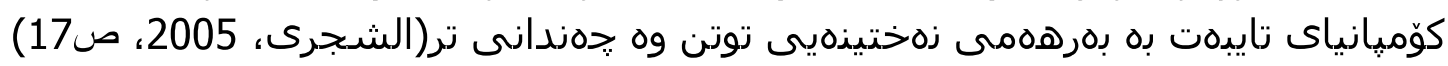

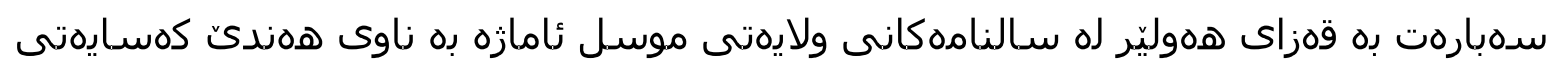
كراوه كه بهريرسى به دارهاى

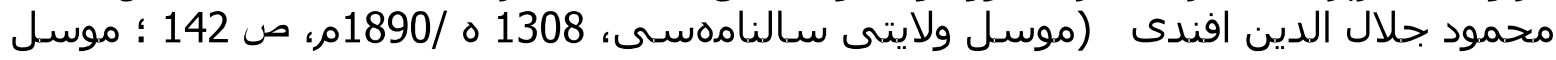

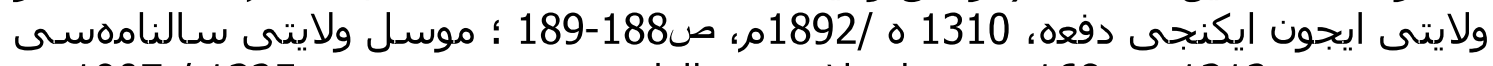

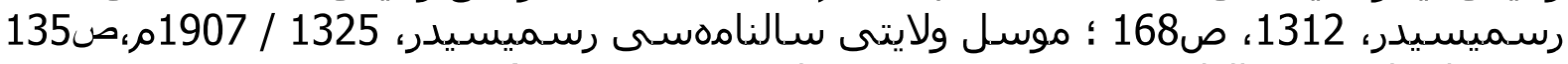

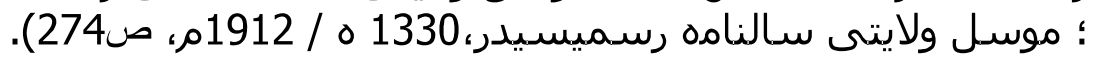

\section{جوارهم - مولكدارى زهوى :}

زهويهكانى قهزاى هذوليّر و جحوّنيهتى بهربّوهبردنيان وهك له سهريجاوهكان ئامازهى يِّكراوه بريتين له سـى جوَربوون زٔهوانيش:

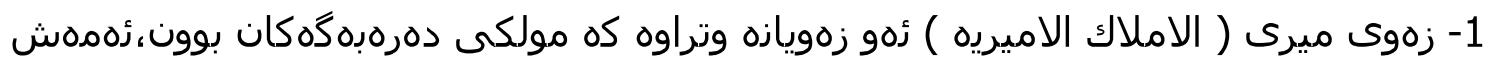

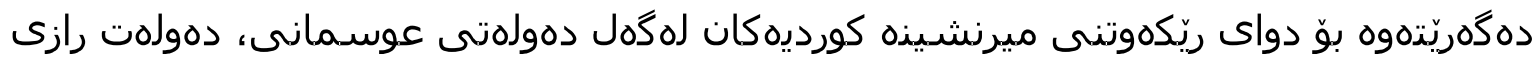

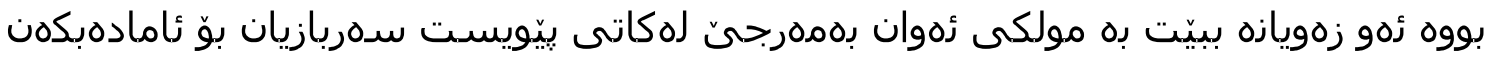




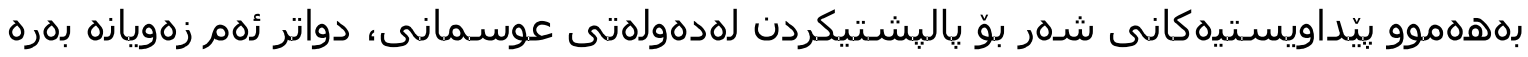

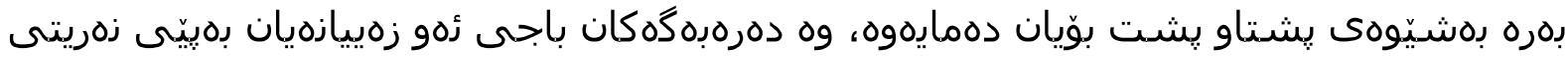

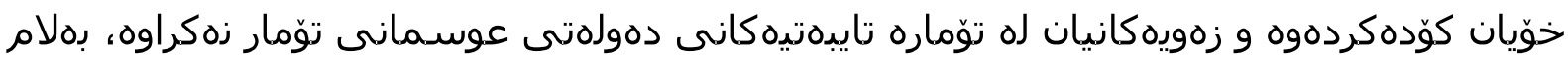

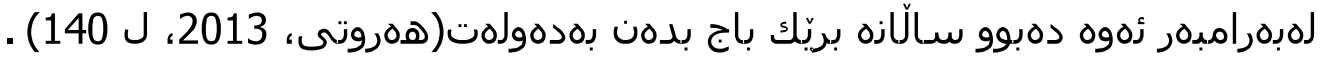

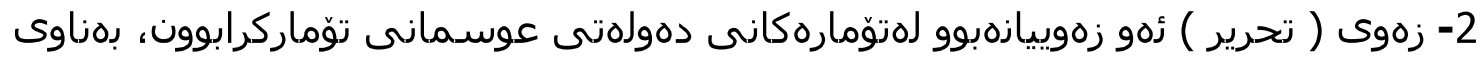

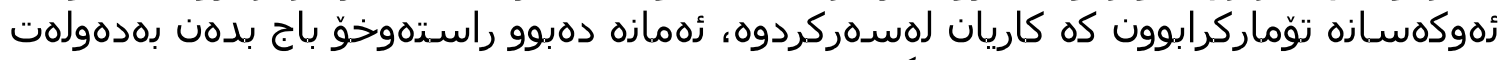

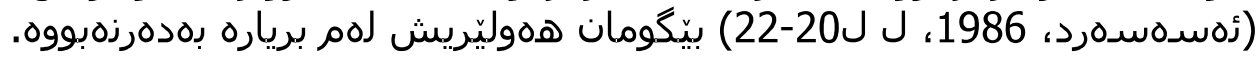

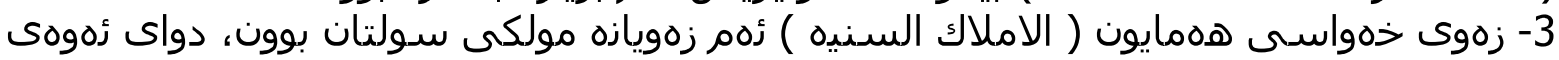

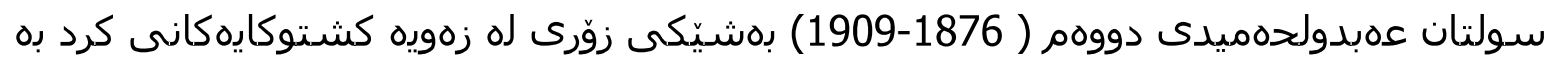

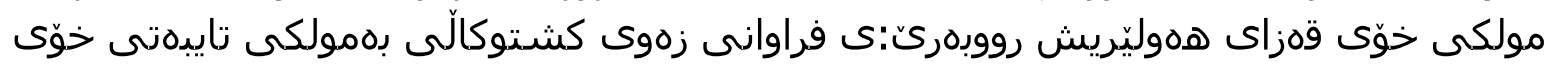

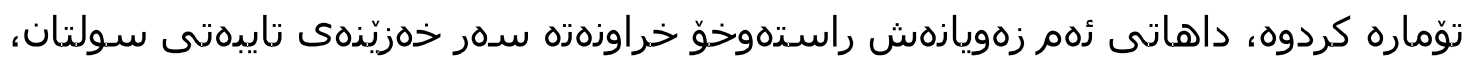

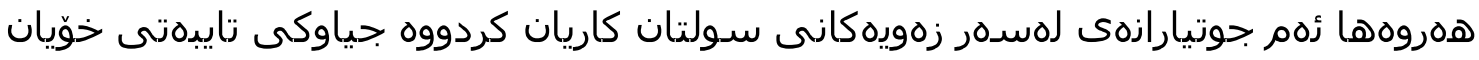

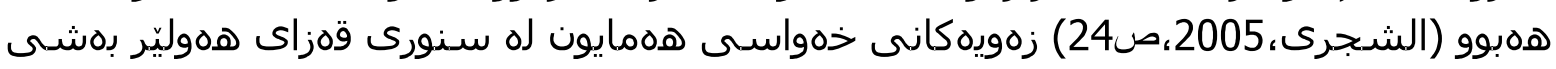

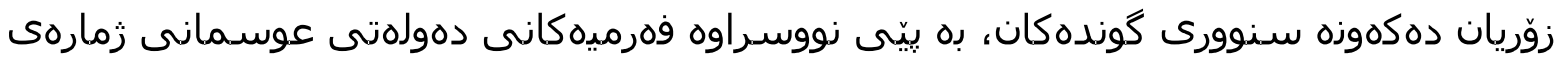

كوندهكانى قهزاى هذوليّر ( 300) گونده كه ( دابهشبووزه بهسهر ناحيه كان (

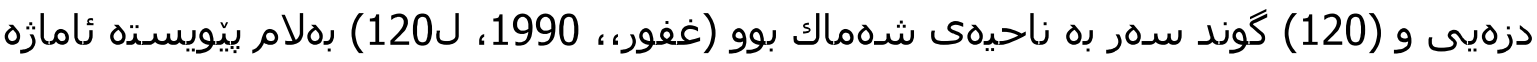

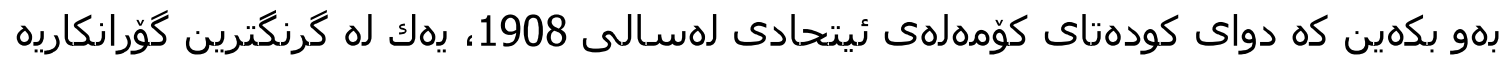

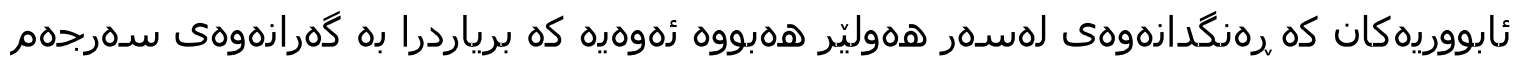

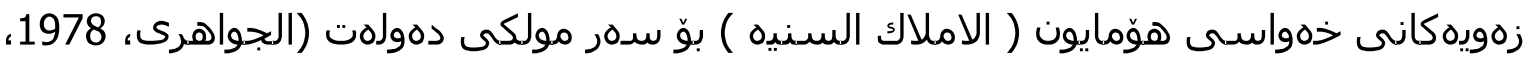
ص 44 ) (

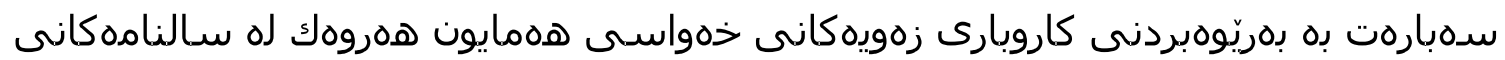

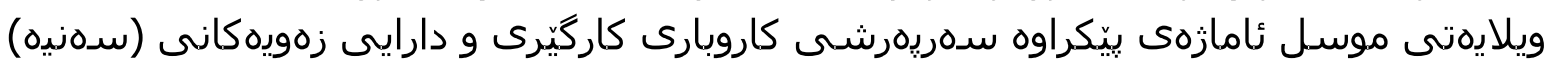

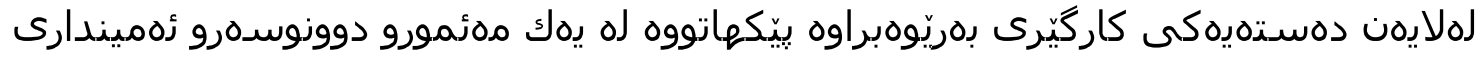

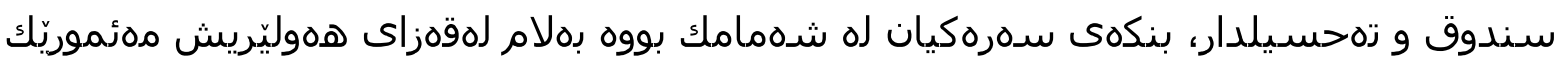

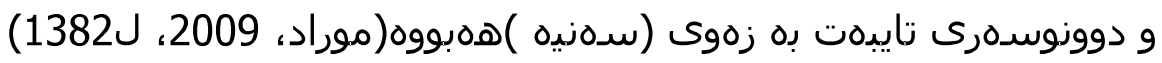

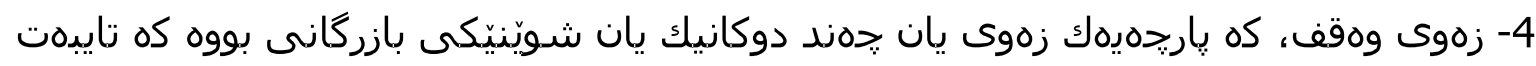

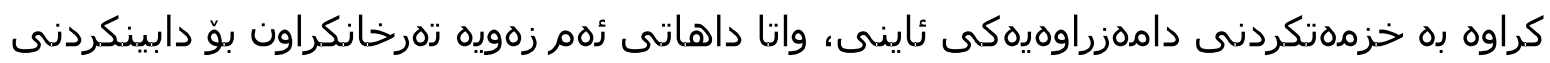

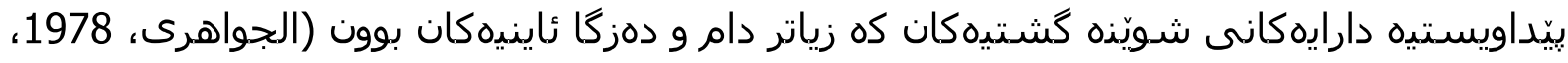

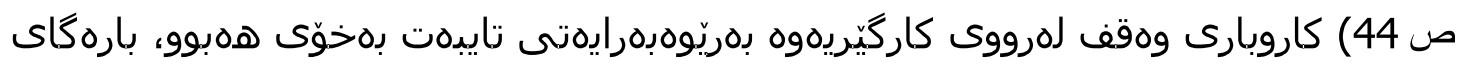

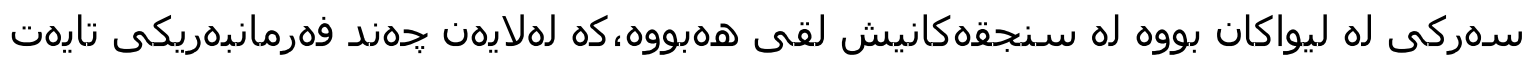

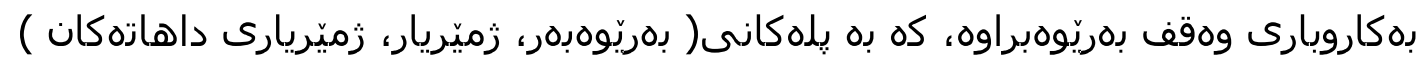

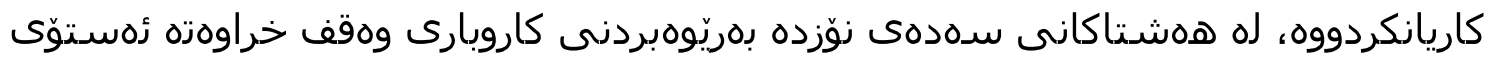

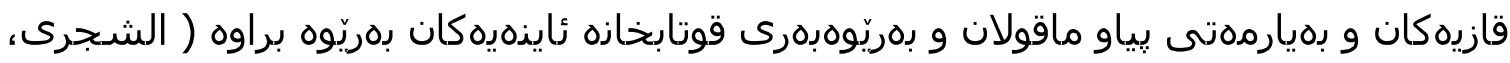
2005، ص17)

سهبارهت به قهزاى هذوليّر لهسالنامهكان ئامازه بهناوى ( سليّمان زهوفهندى ) كراوه وهك

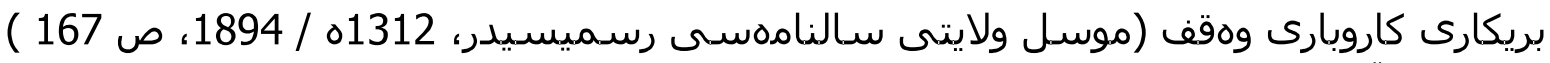

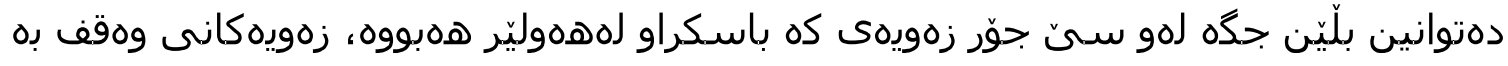

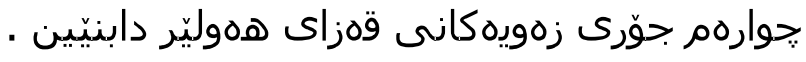




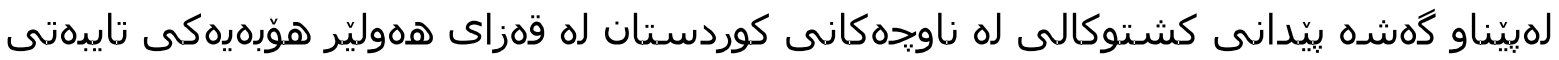

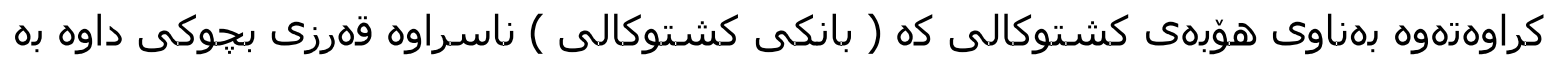

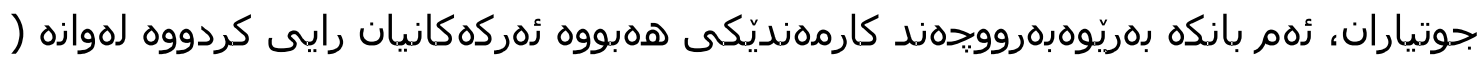

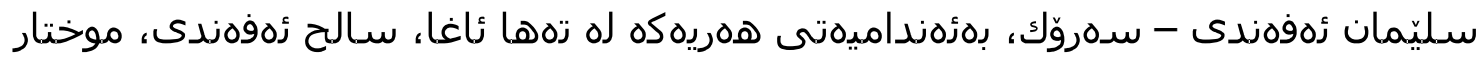

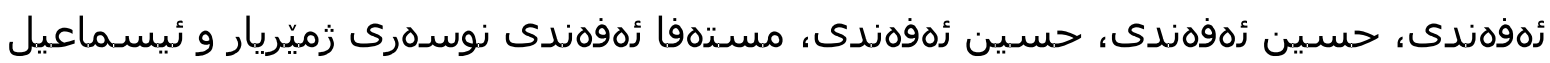

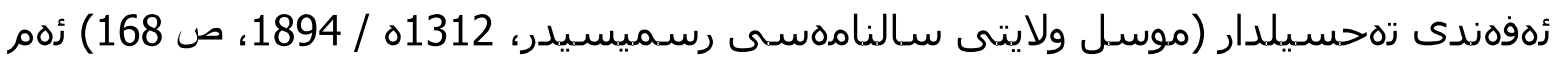

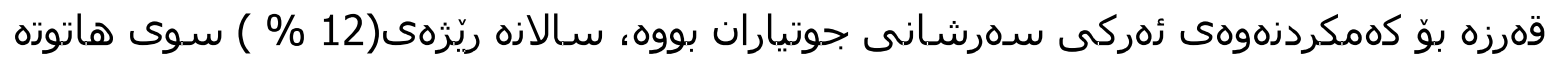

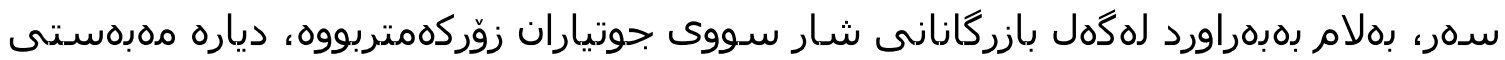

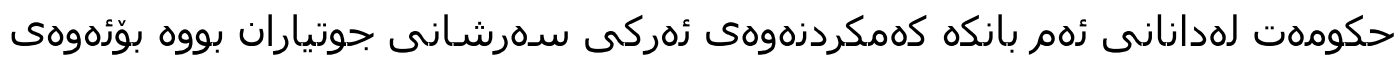

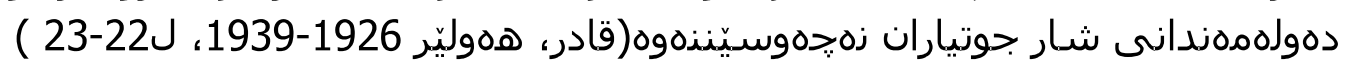

\section{بِينجهمر / بارودوّى ئابوورى ههوليّر لهسالانى جهنكَى يذكهمى جيهانى :}

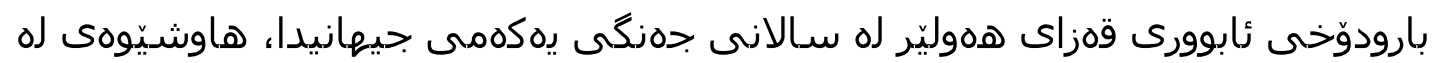

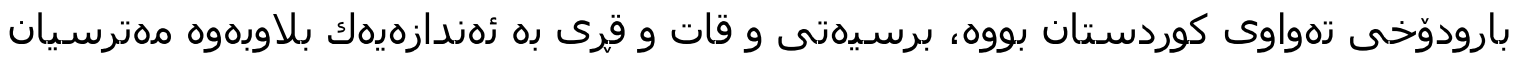

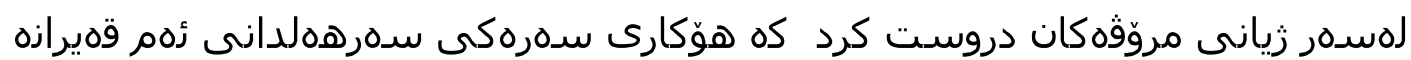

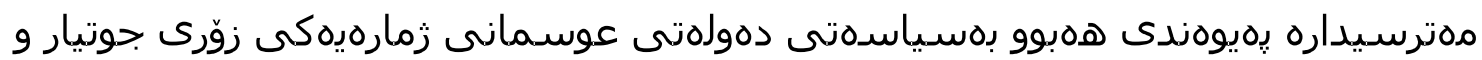

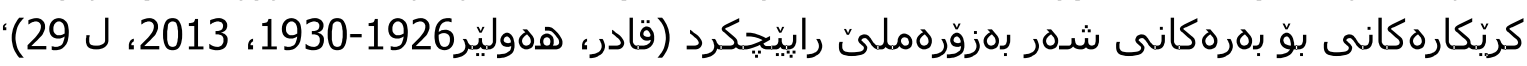

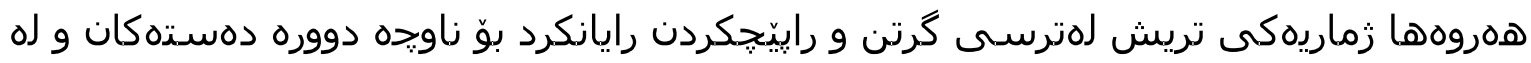

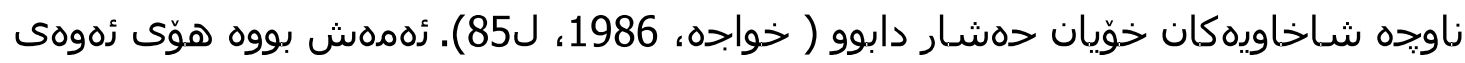

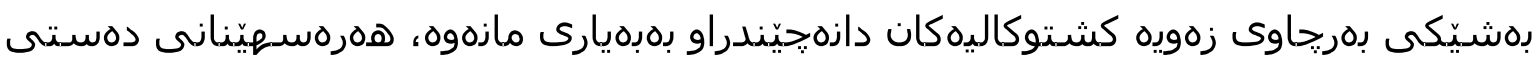

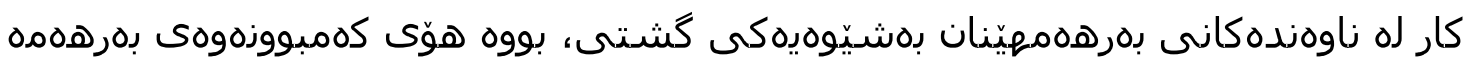

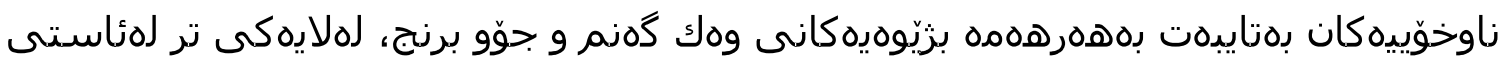

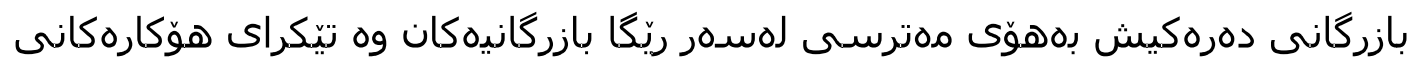

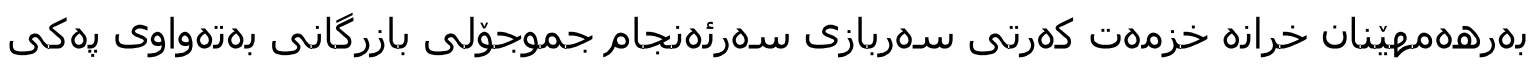

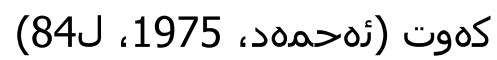

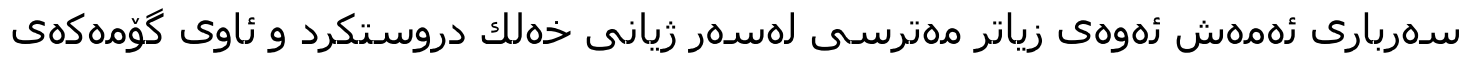

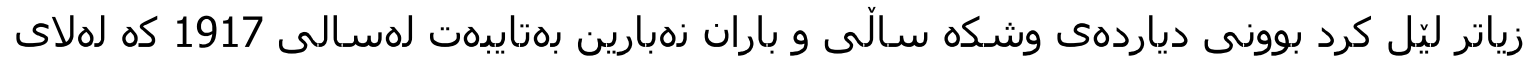

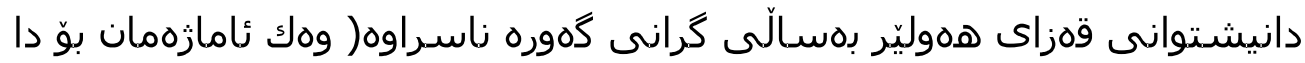

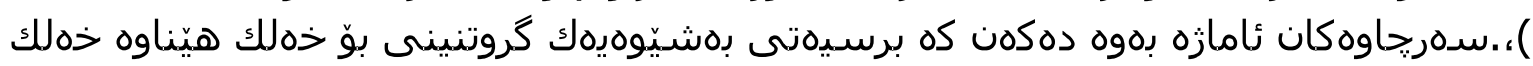

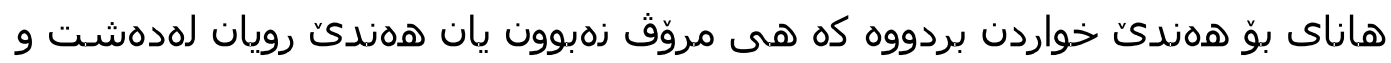

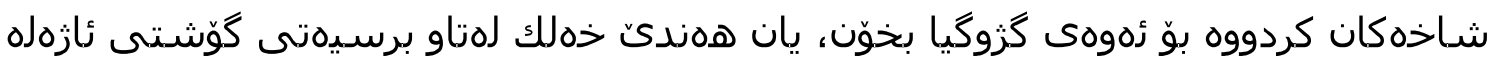

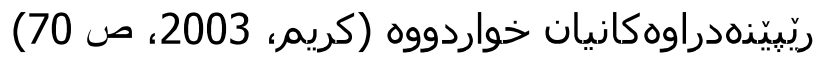

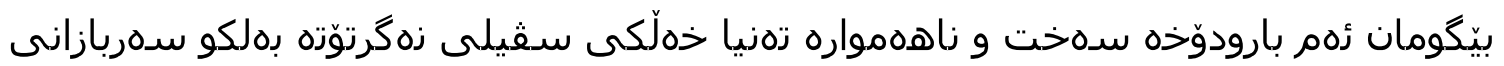

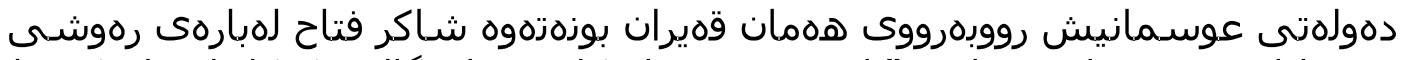

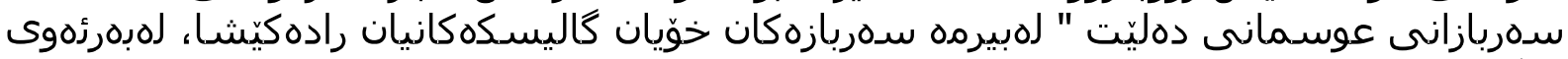

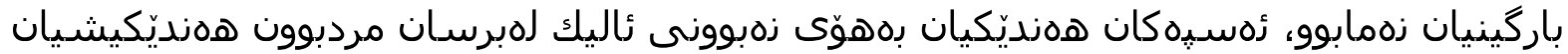

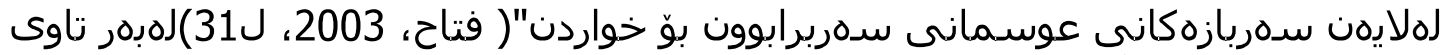

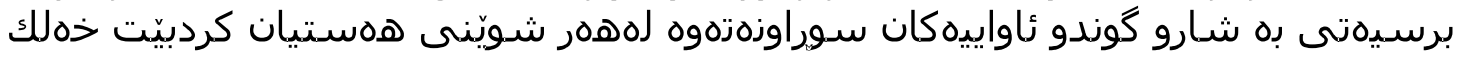

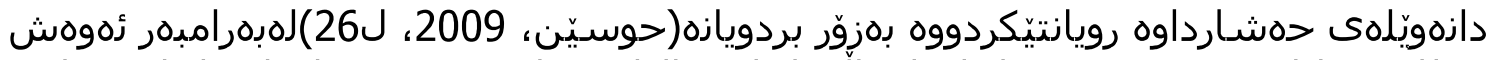

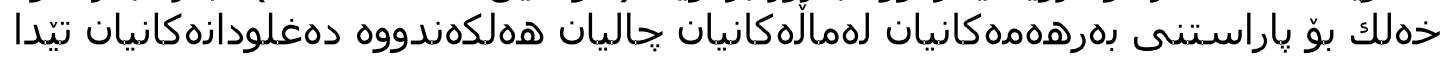

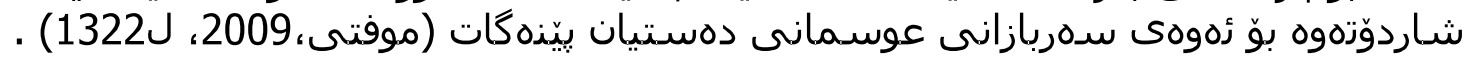




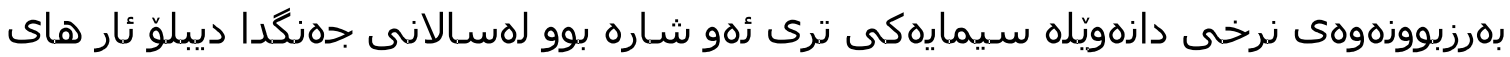

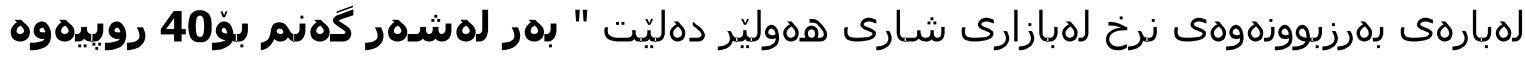

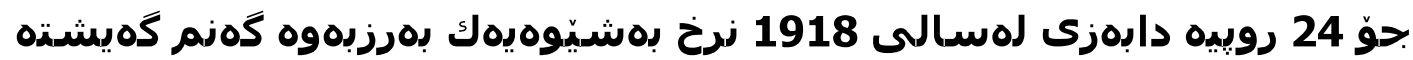

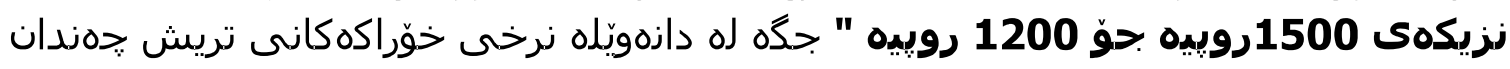

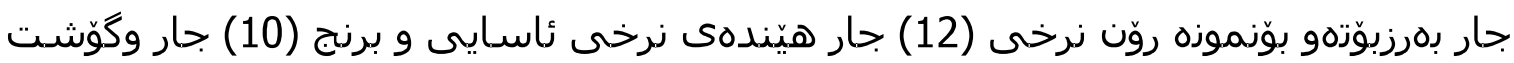

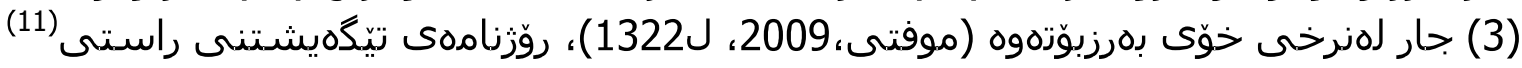

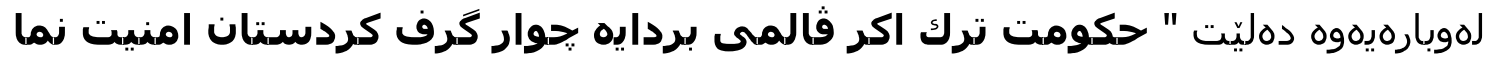

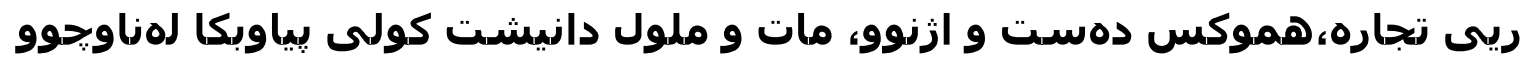

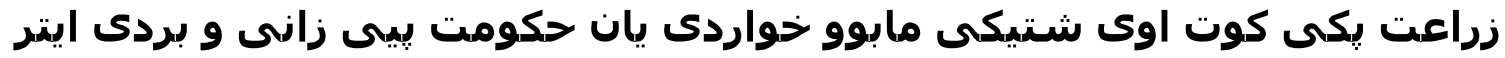

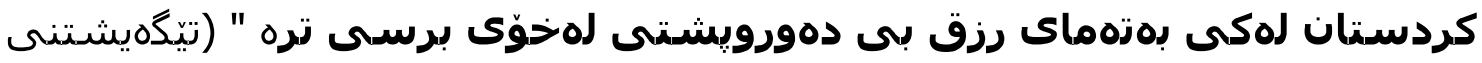

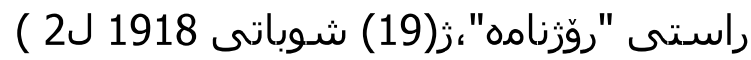

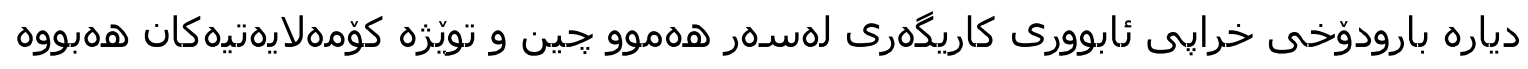

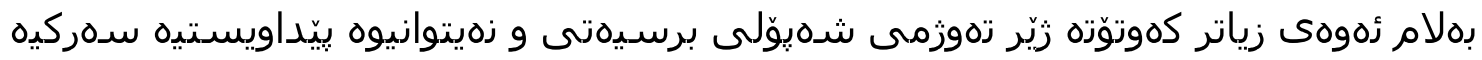

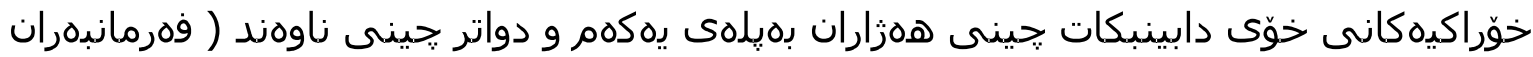

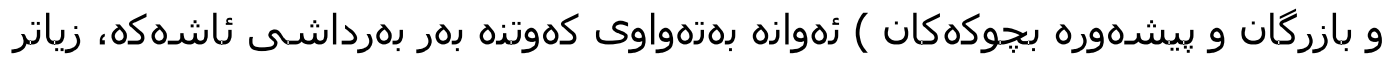

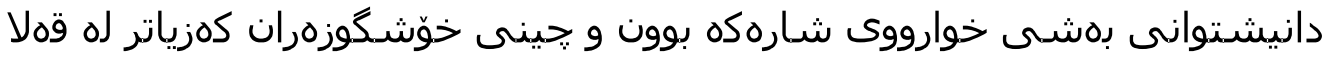

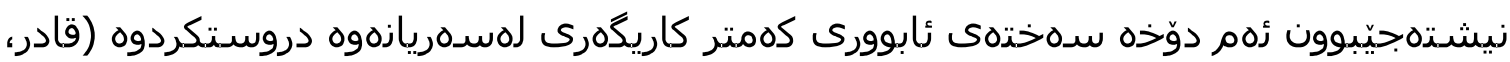

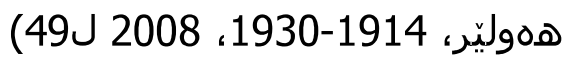

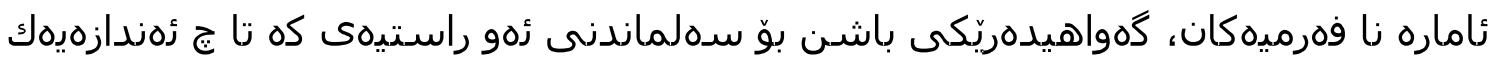

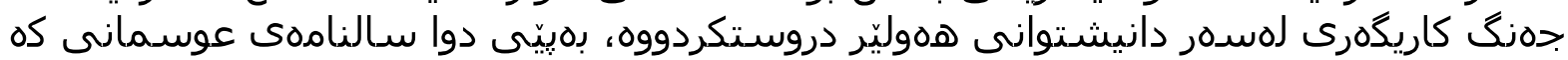

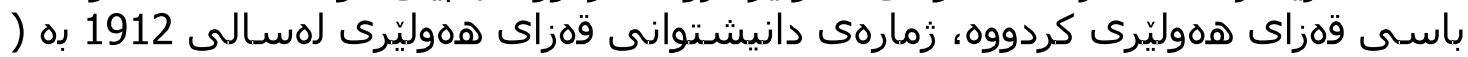

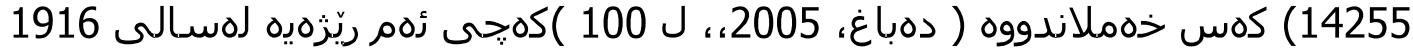

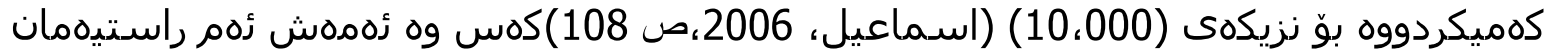

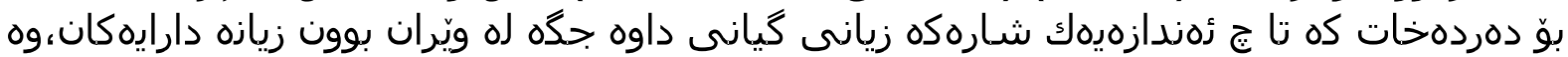

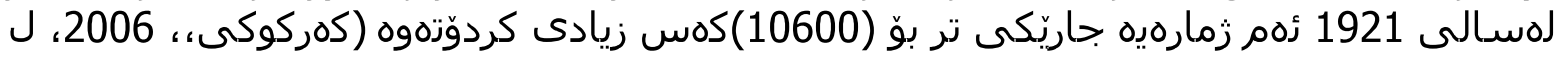

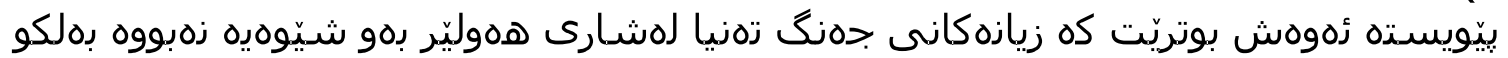

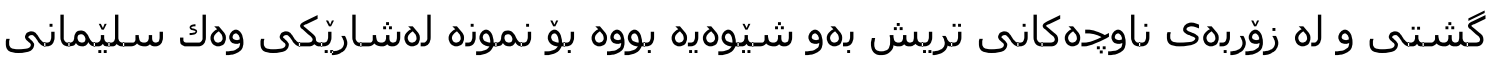

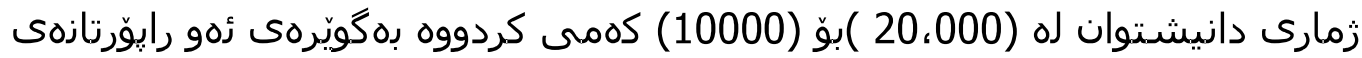

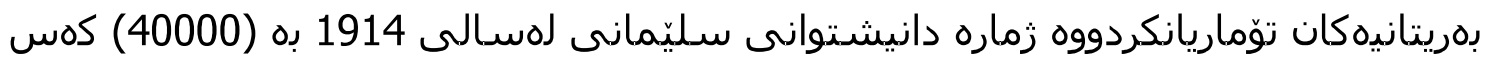

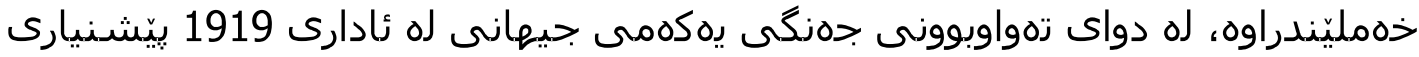

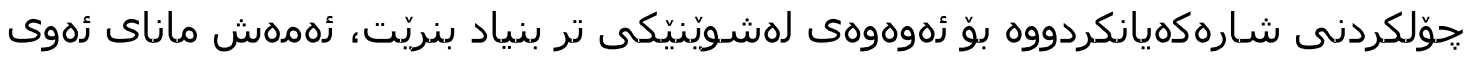

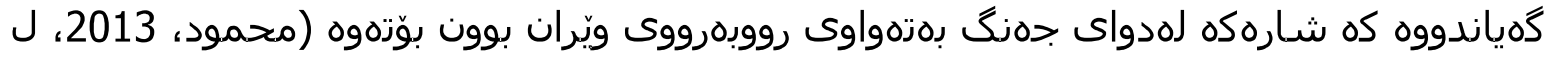

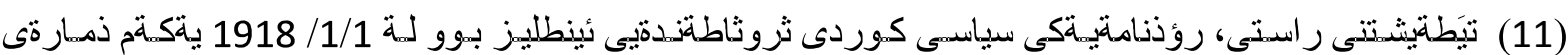

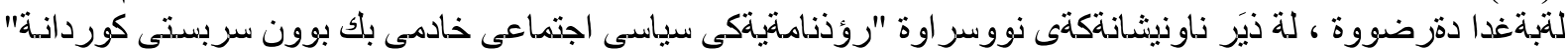

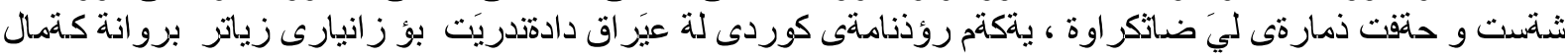

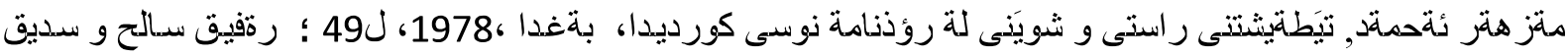

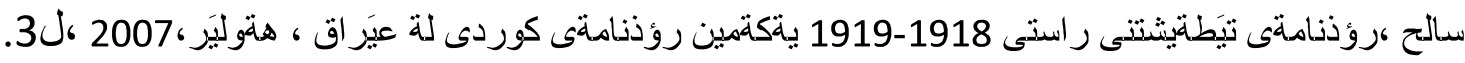

International Journal of Kurdish Studies Vol.5/1 ( January 2019) 


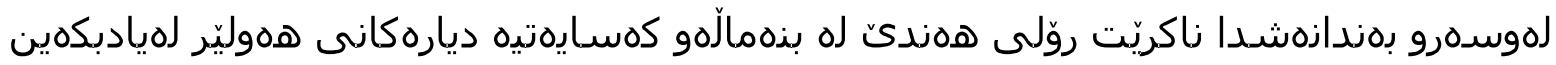

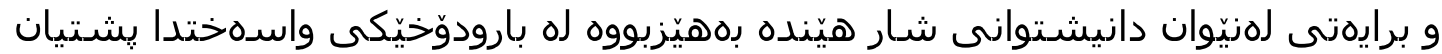

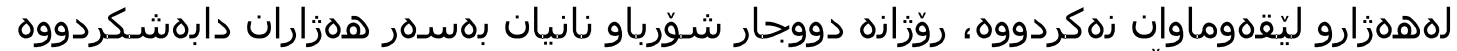

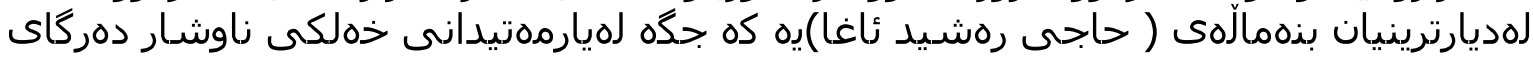

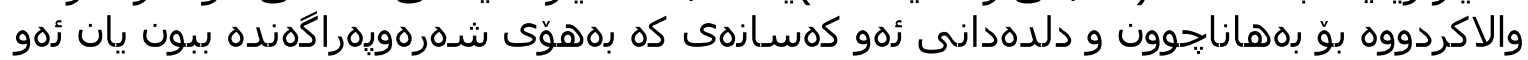

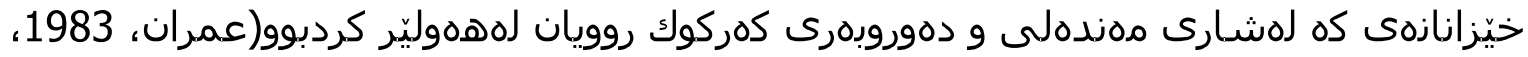

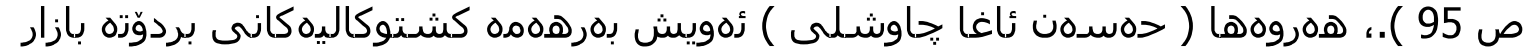

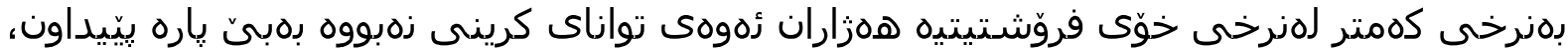

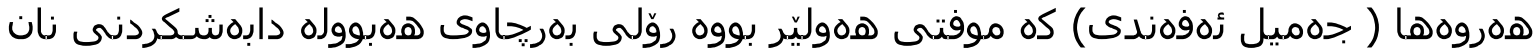

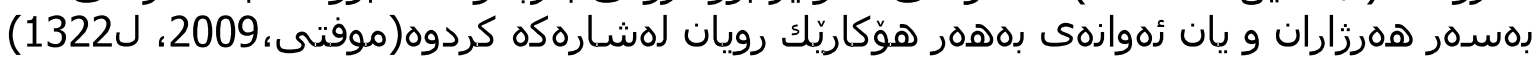

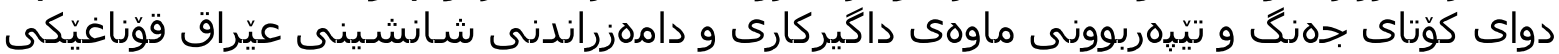

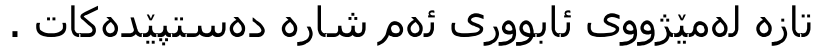

\section{: زٔزمزجام}

لهكوّتاييهكانى سدردهمى عوسمانى ، هذوليّر قهزايهى بووه سهر به ويلايهتى موسل ، لهرووى

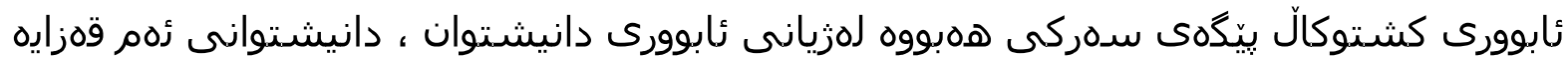

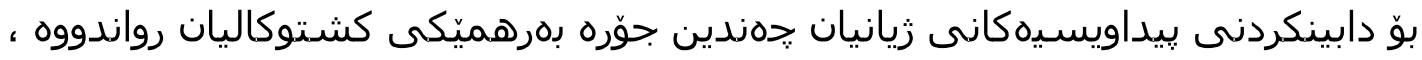

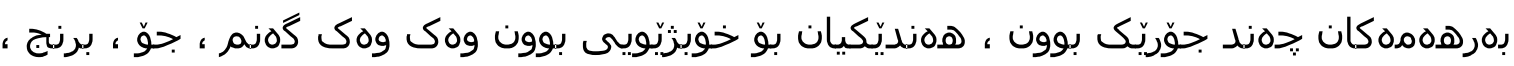

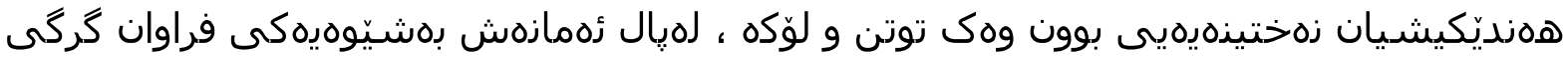

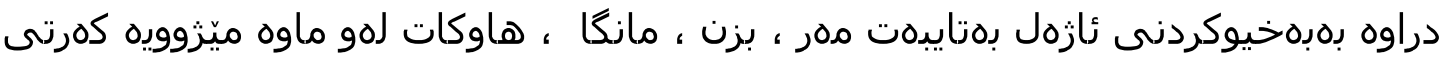

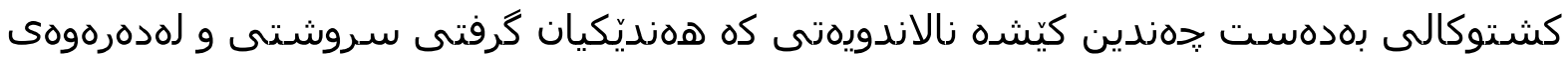

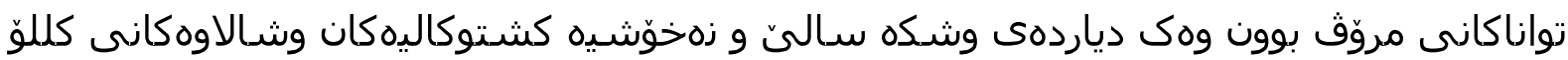

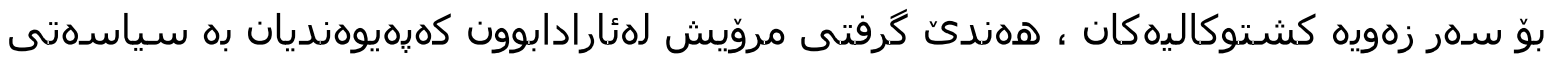

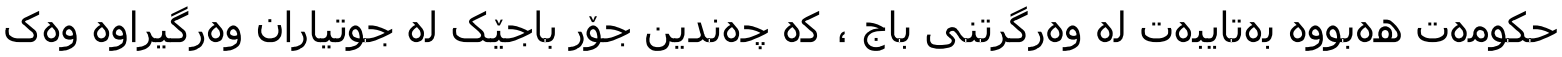

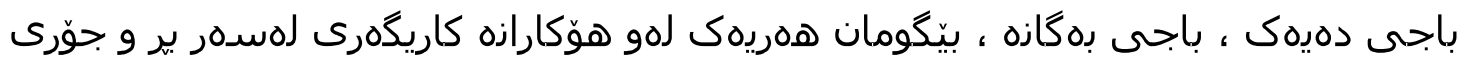

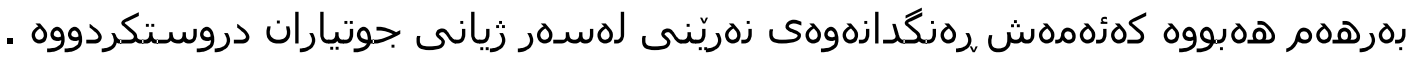

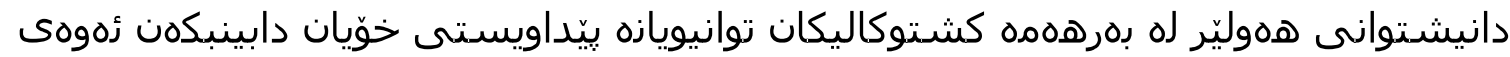

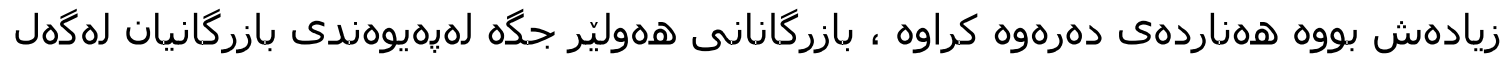

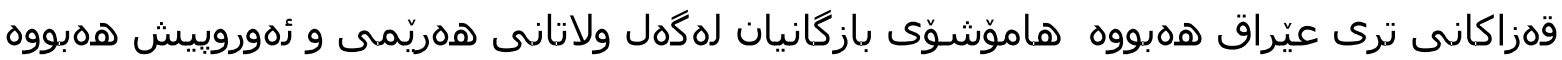

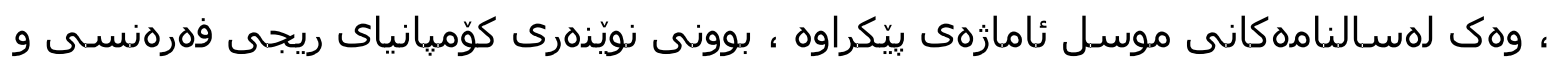

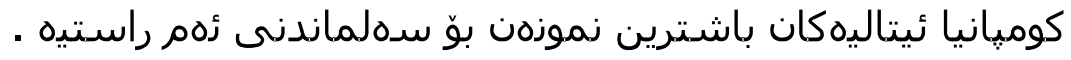

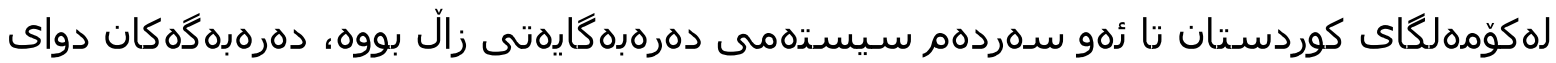

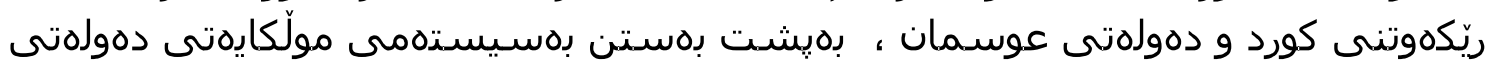

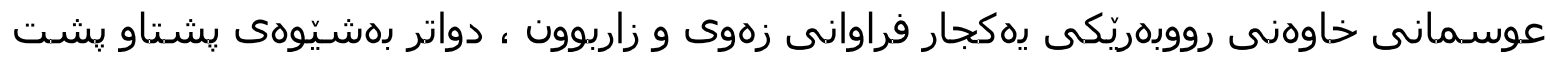

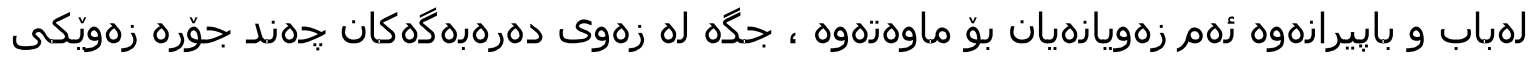

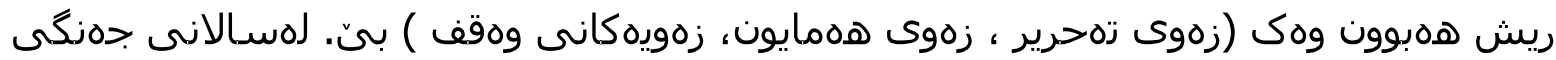

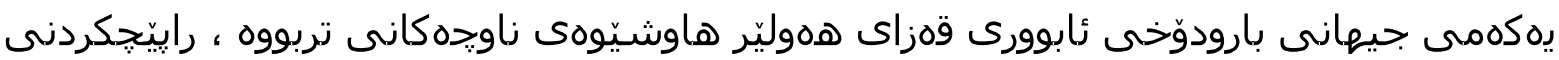

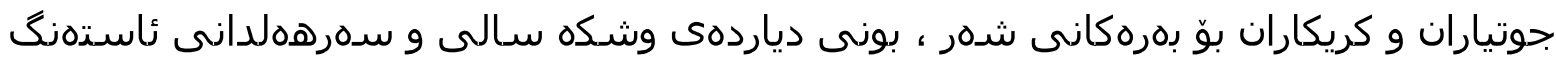

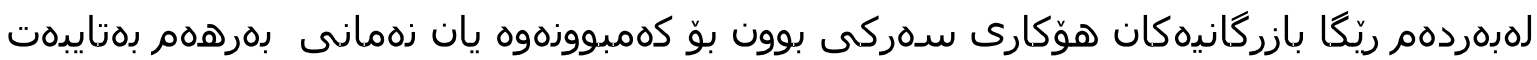




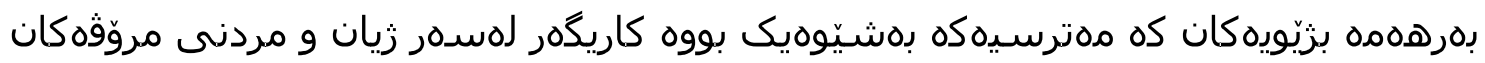
دروستكردووه .

\author{
ليستى سدةرضاوةكان

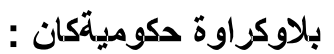 \\ موصل و لايتى سالنامةتى ، برنجى دفعة ، 1308ه / موصل مطبعة سندة طبع اولنمشدر 1308 ه 1890م \\ موصل و لايتى سالنامةتسى رسميسيدر ، 1310ه / 1892 \\ موصل و لايتى سالنامةتسى رسميسيدر ، 1312ه ، 1894 \\ موصل و لايتى سالنامةتسى رسميسيدر ، 1325 ه / 1907 \\ موصل و لايتى سالنامة رسميسيدر ، موصل و لايتى مطبعةسى ، 1330 ه / 1912
} IIRAQ ADMINISTRATION REPORRTS 1914-1932.ARCHIVE EDITIONS.

نامة زانستيةكان :

، الثنجى ، عدنان هزير جودة : النظام الادارى فى العز اق 1920-1939، اطروحة دكتور اه ، كلية الاداب ، جامعة بغداد

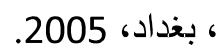

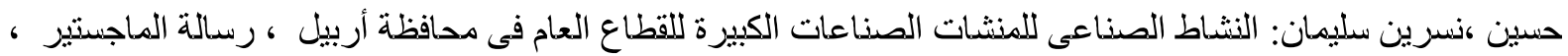
كلية الادارة والاقتصاد ، جامعة صدلاح الدين - أربيل ، 2002.

حبيب ،على محمد على :التبغ فى الدولة العثمانية من اواخر القرن السادس العشر حتى قيام الحرب العالمية الاولى ، رسالة الماجستير جامعة الاسكندرية ، اسكندرية ، 2015.

علي ،غانم محمد : النظام المالي العثماني في العز اق،1839-1914 ، رسالة الماجستير مقدمة الى كلية الاداب- جامعة

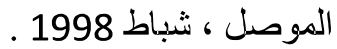

\title{
سمريخانوهان
}

1 - 10 10زمانى كوردى

زهحمهد كهمال مهزههر: كوردستان لهسالهكانى شدرى يهكهمى جيصاندا ، بهغدا ، 1975 .

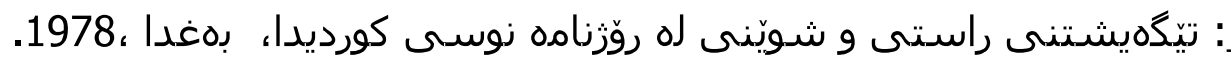

زهسهسدرد ، ف: گهشدكردنى سدرمايهدارى لهكوردستان ، دهزگاى روّشـبير ، ب،ش، 1986. 


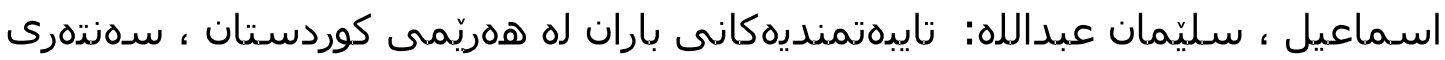
ليّكوّليذهوهى ستراتيزى ، سلينمان ، سـليِمانى ، 1998.

جامباز ، تاريق ، بهرزنجى ، زهزاد ،ئامارى دانيشتوان هذوليّر 1922 سهراى ، تهكيه ، توّيخازهوه، سليِمانى ، 2006

حوسيّن ، جهلال خدر ، رياننامهى شههابرى هذوليّرى 1891-1939، جإِخازهى نازه ، هذوليّر ،

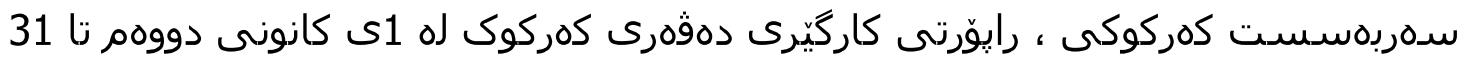

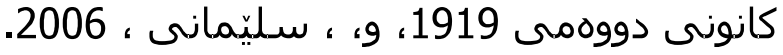

سالح، رهفيق ، روّرَنامهى تيّكْيشتنى راستى 1918-1919 يِكهمين روّرزنامهى كوردى لـ عيّراق ،

״اوشلى ، هادى رشيد ، هذوليّر لهذهل كاروازهى فهلهى ، بهغدا ، 1987 ،

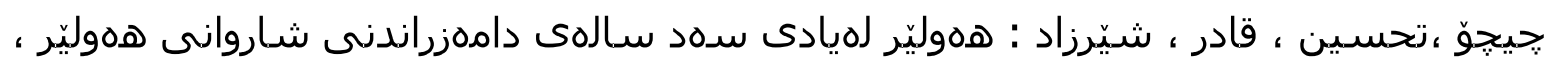
هذوليّر، 1985

عبدالقادر ، نعروّ محمد ، هذولنَّر 1918-1926، هذوليّر ، 2012. غهفور عهبدولا : جوكرافياى كوردستان ، ج4، پإِخازهى وهزارهتى بِهروهرده، هذوليّر ، 2005. فتاح ، شاكر ، ئاويّذى زينم ، سدريحهم بهرهذمهكانى ، هذوليّر ، 2003.

قادر ، معدى محمد ، هذوليّر لهنيّوان سالانى 1914-1930، جإِخازهى روّرههلات، هذوليّر ، 2008

هذوليّر لهسالانى 1926- 1930، جإِخازهى حاجى هاشم ، هذوليّر ، 2013

محمود ، بهختيار سهعيد ، ليواى سليّمانى 1921- 1958ليَكوّليذهوهيهكى ميّزوويى له بارودوّخى ئابورى، سليّمانى ، 2013.

مستهفا ، فاتيمه قادر: دابهشبوونى دانيشتوانى شارى هذوليّر ، مهلبهندى كوردوّلوّجى ،

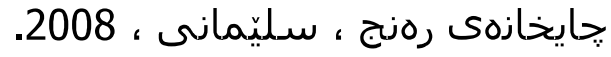

هاملتن ،م: ريّكايهى به كوردستاندا ، و، عهلى عهبدولره>حمان عهسكهرى ، جإِخازهى موكريان ،

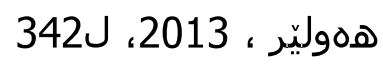

$$
\text { ، سليّمانى ، }
$$

هذروتى ، سدعدى عوسمان : جهذند لايهنيّكى ميّزووى راميارى و كوّمهلايرتى و ئابوورى

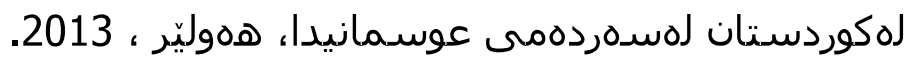

: 2 
الجنايى ، هاثنم حضر : مدينة أربيل در اسة فى جغز افية الحضر ، موصل ، 1987. لجواهرى ، عماد احمد : تاريخ مثكلة الار اضى فى العراق 1914-1932، دار الحرية للطباعة، بغداد، 1978 .

الحاج ،عزيز : القضية الكردية فى العشرينات ،ط2، بغداد ، باد ، 1985.

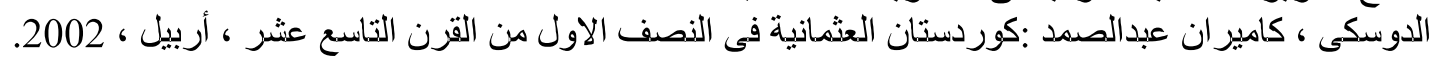
السامر ائى ، سعيد عبود : النظام النقدى والمصرفى فىى العز اق ، بغداد ، 1969. القيسى ، ناهض عبدالززاق: النقود فى العزاق ، بغداد، 2002 ـ.

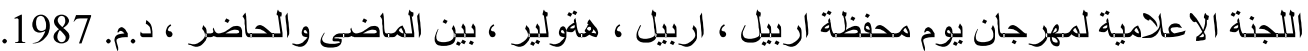

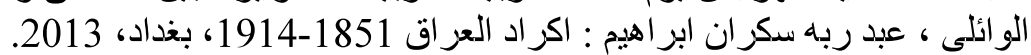

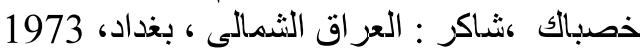

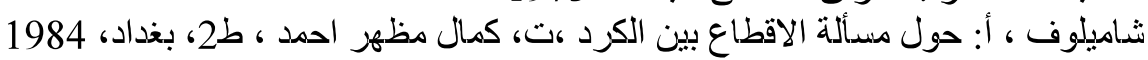

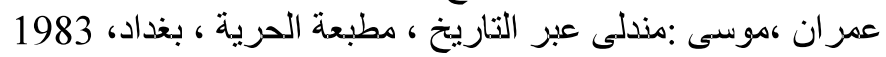
عزاوى، عباس: تاريخ الذقود العز اقية ، بغداد، 1958 كريم ، عمر محمد محمد : القضية الكردية فى الصراع البريطانى العر اقى 1918-1932، هةوليز، 2003 لونكريك، ستيفن هلمس : اربعة قرون فى العزاق الحديث ، ت، جعفر خياط، ط4، بغداد، 1986

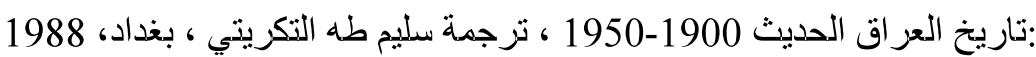

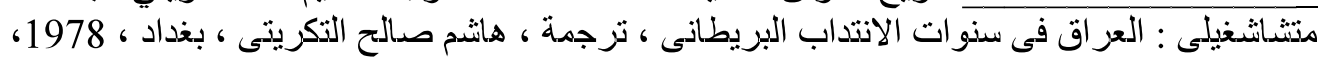

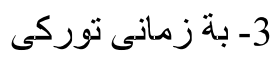

DR.Sinan Marufoglu , OSMANLI DONEMINDE KUZEY IRAK 1831-1914, Istanbul, 1998.

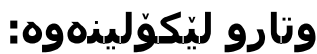

غفور ، عبدالجبار قادر:اربيل فى سالنامات العيمانيه ، كاروان " كوّڤار " ، ز ( 91) ، سالّى نوّيهم .1990،

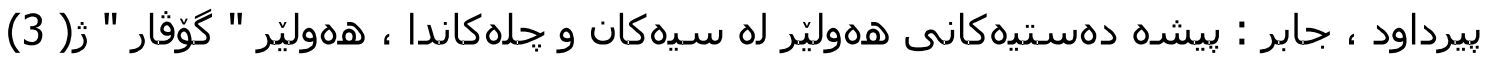

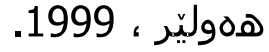

خواجه، زهحمهد: جحند بيرهوهريهكى ميّزووويى ، روّشنبيرى نوى "كوّوار" ز ( 111) 1986، دهباغ ، عبدالرزاق: مامهكانم قهيسهرى هذوليّريان دروستكرد، ئامادكردنى ، يوسف نازهكهلى ،

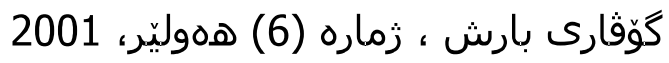

دهباغ ، وهيسهل : هذليّر لهسالنامهكانى ويلايهتى يهتى موسل دا، هذوليّر "كَوَڤار" ، ث (5)

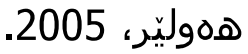




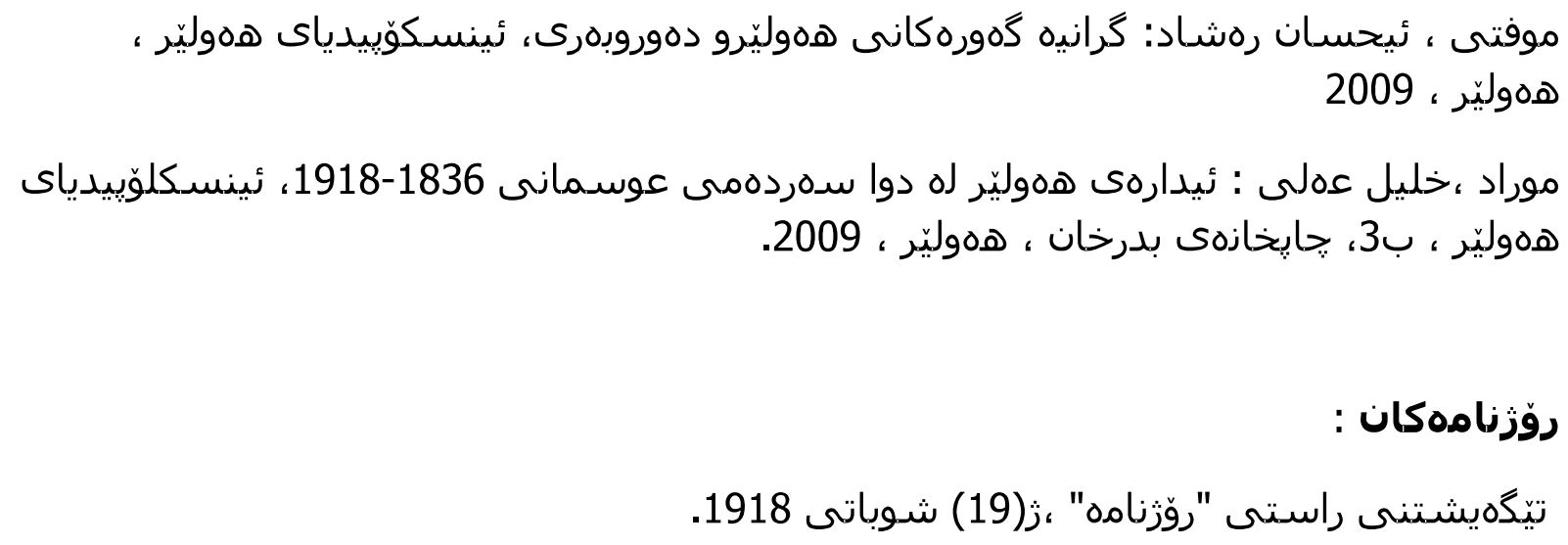

\section{References}

Aasasard, F., (1986). Capitalist growth in Kurdistan

Abdulqadir, N., (2012). Hewler ( Erbil) in the years 1918-1926, Erbil

Ahmad, K., (1975). Kurdistan in the first years of the war. Baghdad

Ahmma, K., (1978). "Tegayshtny Rasti" Newspaper, Baghdad

Ali, G., (1998). Ottoman financial system in Iraq, 1839-1914, Master's thesis submitted to the Faculty of Arts-Mosul University, Mosul

Aldosky, K., (2002). Ottoman Kurdistan in the first half of the nineteenth century, Erbil,

Alhaj, A., (1985). The Kurdish Issue in the Twenties, Baghdad

Aljanaby, H., (1987). Erbil City Study in urban geography, Mosul

AlJawahery, A., (1978). History of the Land Problem in Iraq 1914-1932, Baghdad

Alqaesy, N., (2002). Money in Iraq, Baghdad

Alsammaraie, S. (1969). Monetary and banking system in Iraq, Baghdad

Alshajary, A. (2013). Iraqi administrative system 1920-1939, PhD thesis, Faculty of Arts

Alwaely, A., (2013). Iraqi Kurdsh, 1851-1914, Baghdad

Azawy, A., (1958). History of Iraqi Money, Baghdad

Chawshle, H., (1987). Erbil in astronomical rotation, Baghdad

Checho, T., (1985). Erbil on a public occasion to establish the municipality of Erbil, Erbil

Dabbagh, F., (2005). Erbil in Salnamat Mosul state , Hewler "Magazine", p (5), Erbil 
Dabbagh, A., (2001). My uncle is the founder of the Caesare market of Arbil, Barsh"Magazine", p (6), Erbil

Fatah, S., (2003). Mirror of my life, Erbil

Ghafor A. Kurdistan geography, Erbil, 2005.

Ghafor j. Arbil in Ottoman Sallanama Karwan"Magazine", p (91), Erbil, 1999 .

Habib A. Tobacco in the Ottoman Empire from the late 16th century until the First World War, Master's thesis, Alexandria University, Alexandria, 2015.

HamiltonA. Road Through Kurdistan , Trasted by , Abdulrahman A,Erbil,2013.

Haroty S. Historical, political, social and economic aspects of Kurdistan in the Ottoman era, Erbil, 2013.

Hussein j. Life artist Shahaba Erbeli (1891-1939) Erbil,2009.

Hussein ,N. Industrial activity of the large public sector industries in Erbil Governorate, Master's thesis, Faculty of Administration and Economics, Salahaden University, Erbil, 2002.

IRAQ , ADMINISTRATION REPORRTS 1914-1932 , ARCHIVE EDITIONS,1919

Ismail S. Characteristics of the rain of Kurdistan region, . Silemany,2006.

Jambaz T. Population census of Erbil, 1922. Erbil. 2006

Baghdad, 1984.

Karem U. The Kurdish Issue in the British-Iraqi Conflict 1918-1932, Erbil, 2003.

Khesbak Sh. North Iraq a Physcal and Cultural Study, Baghdad,1974.

Kirkuky S . Britsh Administration Report of Kirkuk Division, Silemany,2006.

Longrigg S. Four centuries in modern Iraq, translation, Jaafar Khayat, Baghdad, 1986.

Longrigg,S ,Iraq modern 1900-1950, translated by Tikriti S , Baghdad, 1988.

Marufoglu S , Northern Iraq in the Ottoman era 1831-1914(OSMANLI DONEMINDE KUZEY IRAK 1831-1914), Istanbul, 1998

Morad X , Erbil administration in the late Ottoman era 1836-1918, Erbil Encyclopedia , Erbil , 2009.

MosiA. Mendele through history, Baghdad, 1983.

Mosul S. (Mosul Wlaeat Salnammase) Mosul, 1890 
Mosul S. (Mosul Wlaeat Salnammase) Mosul, 1892

Mosul S. (Mosul Wlaeat Salnammase) Mosul ,1894

Mosul S. (Mosul Wlaeat Salnammase) Mosul, 1907

Mosul S. (Mosul Wlaeat Salnammase) Mosul, 1912

Mtshishgheily. Iraq in the British Mandate Years, translation, Hashim Saleh al-Tikriti, Baghdad, 1978.

MuftyE. The major crisis in Erbil, the Encyclopedia of Erbil, 2009.

Mustaffa F. Geographic division of the population Erbil, Erbil, 2008

Perdawed j. Handmade in Erbil. Hewler "Magazine", p (5) Erbil, 1999

QadirM . Hewler( Erbil) in the years 1914-1930, Erbil, 2008.

QadirM . Hewler( Erbil) in the years 1926-1930, Arbil, 2013.

Salih R " "Tegayshtny Rasti" Newspaper, The first Kurdish newspaper in Iraq, Erbil ,2007.

ShamyaloveA. About the question of feudalism between Kurd, translation, Ahmed A, Baghdad, 1984.

"Tegayshtny Rasti" Newspaper . p( 19), Baghdad, 1918.

Xwaja.A, On the historical anniversary, Roshnbery New "Magazine", p (111), Arbil, 1986

يوخته

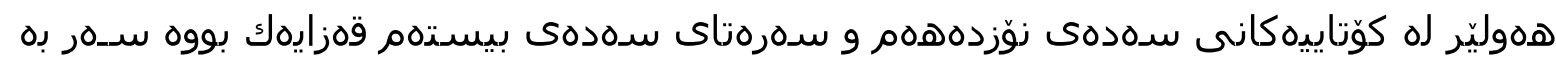

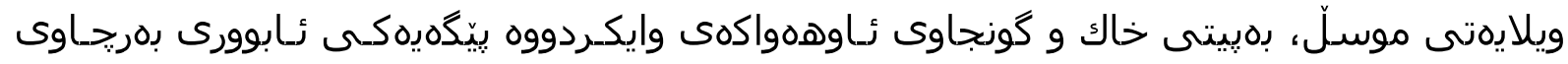

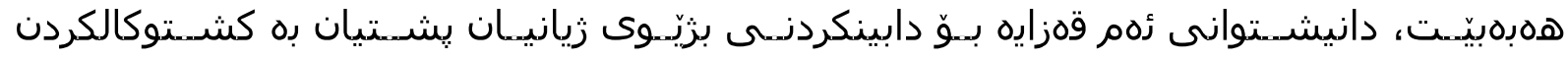

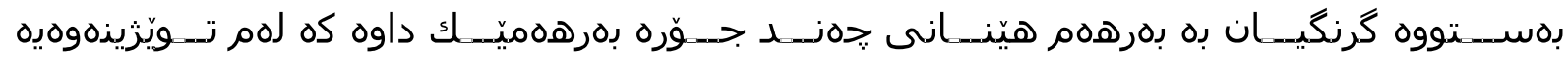

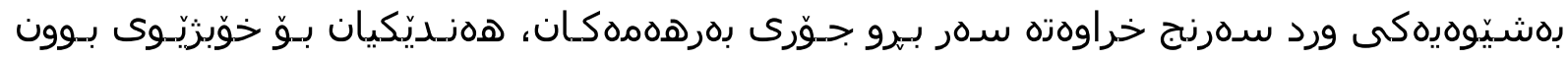

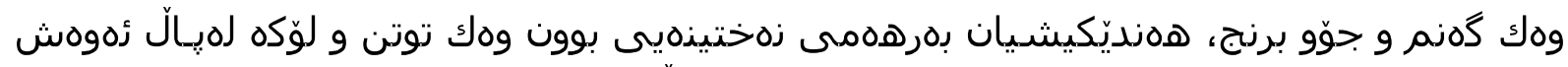

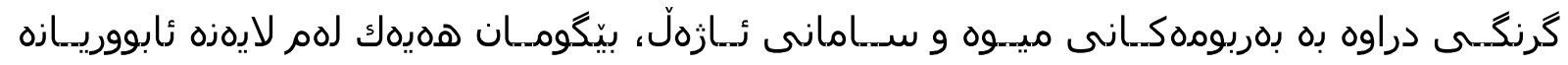

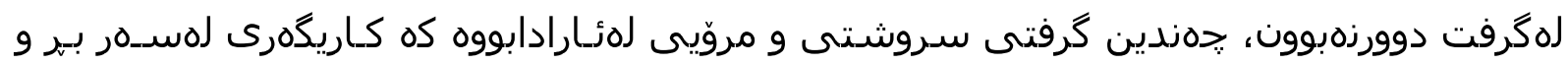

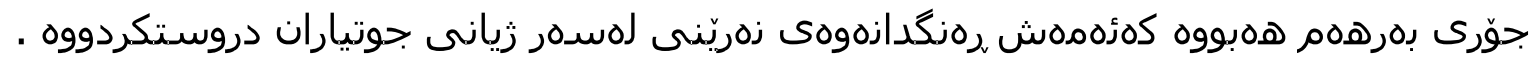

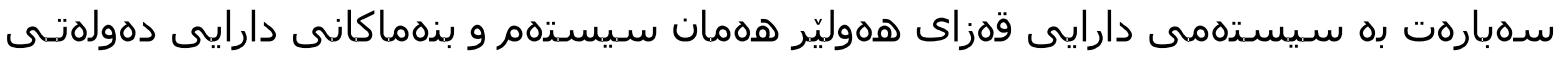

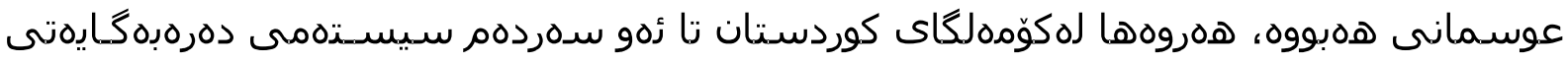
International Journal of Kurdish Studies Vol.5/1 ( January 2019) 


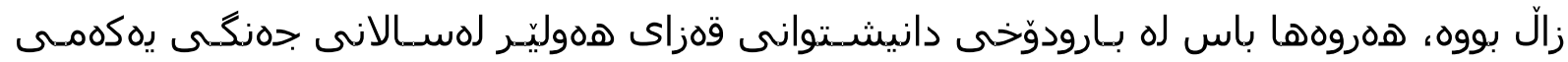

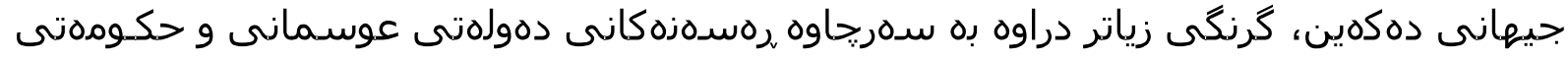

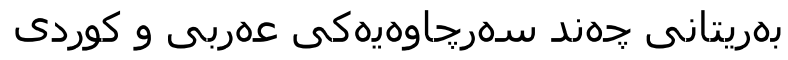

خلاصة

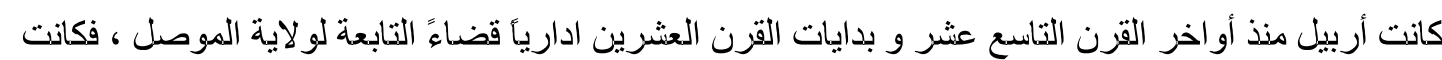

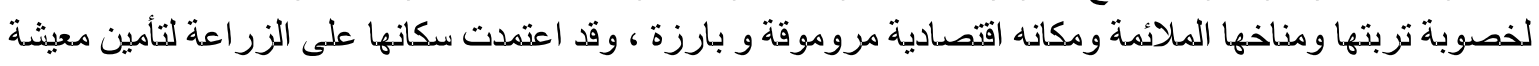

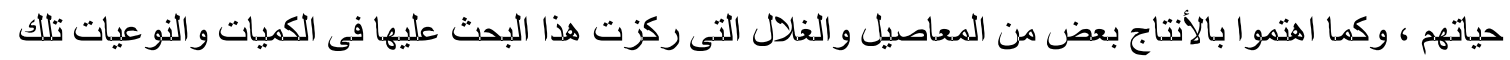

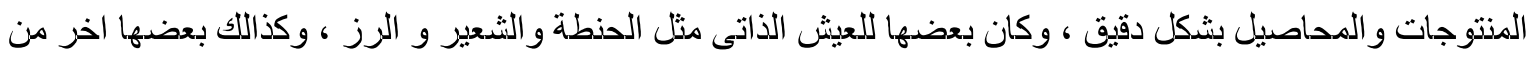

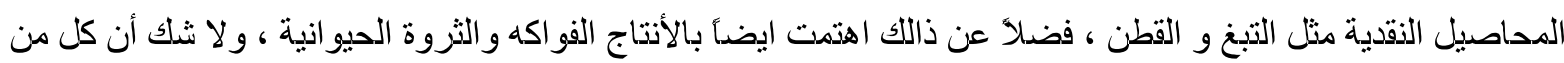

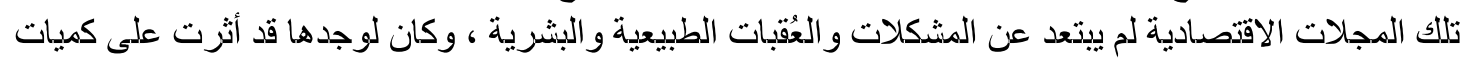

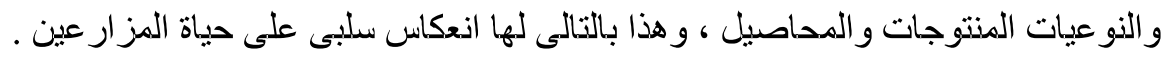

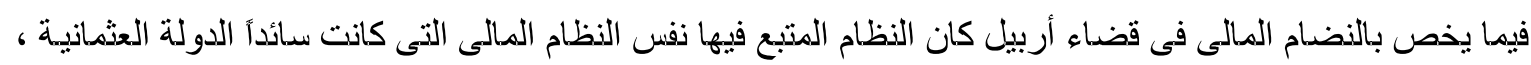

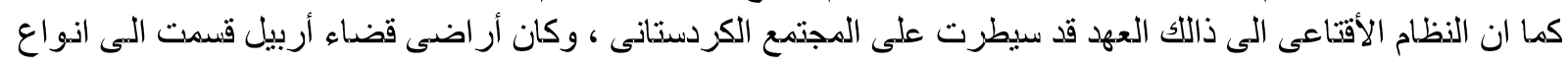

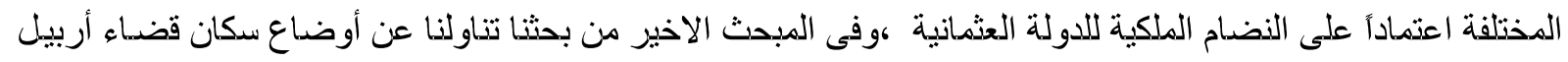

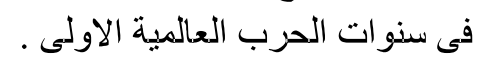

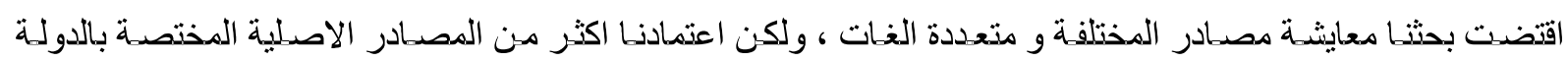

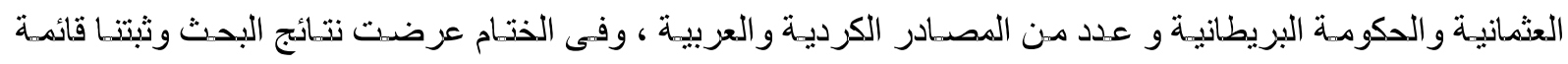
المصادر. 